IZA DP No. 8154

The Welfare State and Anti-Poverty Policy in Rich Countries

Ive Marx

Brian Nolan

Javier Olivera

April 2014 


\title{
The Welfare State and Anti-Poverty Policy in Rich Countries
}

\author{
Ive Marx \\ University of Antwerp \\ and IZA
}

Brian Nolan

University College Dublin

Javier Olivera

University of Luxembourg

\section{Discussion Paper No. 8154 \\ April 2014}

IZA
P.O. Box 7240
53072 Bonn
Germany

\author{
Phone: +49-228-3894-0 \\ Fax: +49-228-3894-180 \\ E-mail: iza@iza.org
}

\begin{abstract}
Any opinions expressed here are those of the author(s) and not those of IZA. Research published in this series may include views on policy, but the institute itself takes no institutional policy positions. The IZA research network is committed to the IZA Guiding Principles of Research Integrity.

The Institute for the Study of Labor (IZA) in Bonn is a local and virtual international research center and a place of communication between science, politics and business. IZA is an independent nonprofit organization supported by Deutsche Post Foundation. The center is associated with the University of Bonn and offers a stimulating research environment through its international network, workshops and conferences, data service, project support, research visits and doctoral program. IZA engages in (i) original and internationally competitive research in all fields of labor economics, (ii) development of policy concepts, and (iii) dissemination of research results and concepts to the interested public.
\end{abstract}

IZA Discussion Papers often represent preliminary work and are circulated to encourage discussion. Citation of such a paper should account for its provisional character. A revised version may be available directly from the author. 


\begin{abstract}
The Welfare State and Anti-Poverty Policy in Rich Countries

This paper is prepared as a chapter for the Handbook of Income Distribution, Volume 2 (edited by A. B. Atkinson and F. Bourguignon, Elsevier-North Holland, forthcoming). Like the other chapters in the volume (and its predecessor), the aim is to provide a comprehensive review of a particular area of research. The aim of this chapter is to highlight some key aspects of recent economic research on the welfare state and anti-poverty policy in rich countries, and explore their implications. We begin with the conceptualisation and measurement of poverty, before sketching out some core features and approaches to the welfare state and anti-poverty policies. We then focus on the central plank of the modern welfare state's efforts to address poverty, namely social protection, discussing in turn the inactive working-age population, child income support, in-work poverty, and retirement and old-age pensions. After that we discuss social spending on other than cash transfers: the labour market, education, training and activation, and finally intergenerational transmission, childhood and neighbourhoods. We also discuss the welfare state and anti-poverty policy in the context of the economic crisis which began in 2007-8, and the implications for strategies aimed at combining economic growth and employment with making serious inroads into poverty. We conclude with highlighting directions for future research.
\end{abstract}

JEL Classification: $\quad$ 13, I38, D63

Keywords: poverty, anti-poverty policy, redistribution, welfare state

Corresponding author:

Ive Marx

University of Antwerp

S.M. 181

St Jacobstraat 2

2000 Antwerp

Belgium

E-mail: ive.marx@uantwerpen.be 


\section{The Welfare State and Anti-Poverty Policy in Rich Countries ${ }^{1}$}

\section{Section 1: Setting the Scene}

\subsection{Introduction}

Seen by some as primarily a manifestation of inequality in the distribution of income and wealth and by others as a distinctive phenomenon, poverty continues to represent a core challenge for rich countries and their welfare states. This is reflected in the very substantial body of research on poverty in industrialised countries, both country-specific and comparative, which seeks to capture the extent of poverty and how it is changing over time, understand its nature, and assess the effectiveness of policies and strategies aimed at addressing it. Poverty is widely regarded as a key social concern in most rich countries, not only in terms of the quality of life of those affected but also their wasted potential, as well as the risks to the social fabric and social cohesion more generally. (Chapter 24 by Martin Ravallion argues that the notion that poverty not only should but can be eliminated in such countries is a relatively recent development, and also discusses in depth the links between poverty and macroeconomic performance). While the nature of poverty and how best to tackle it remain hotly contested at a political and ideological level, the focus of research has increasingly been on the effectiveness or otherwise of anti-poverty policies and strategies, which the recent economic crisis has served only to reinforce.

The aim of this chapter is to highlight some key aspects of recent economic research on the welfare state and anti-poverty policy in rich countries, and explore their implications. A core theme will be that the way poverty is conceptualised and measured has fundamental implications for how anti-poverty policy is thought about, designed and implemented. We therefore begin Section 1 with conceptualisation and measurement and key patterns and trends (on which see also Jäntti and Danziger, 2000), before sketching out some core features and approaches to the welfare state and anti-poverty policies. Section 2 then focuses on the central plank of the modern welfare state's efforts to address poverty, namely social protection, discussing in turn the inactive working-age population, child income support, inwork poverty, and retirement and old-age pensions. Section 3 looks beyond social protection

\footnotetext{
1 We thank participants at the April 2013 Conference "Recent Advances in the Economics of Income Distribution" held at the Paris School of Economics and organized by A.B. Atkinson and F. Bourguignon. Particularly thanks go to Rolf Aaberge who served as the main discussant of this paper.
} 
to discuss social spending on other than cash transfers, the labour market, education, training and activation, and finally intergenerational transmission, childhood and neighbourhoods. Section 4 discusses the welfare state and anti-poverty policy in the context of the economic crisis which began in 2007-8, and the implications for strategies aimed at combining economic growth and employment with making serious inroads into poverty. Finally, Section 5 highlights directions for future research.

\subsection{Conceptualising and Measuring Poverty}

The definition of poverty underpinning most recent research in Europe relates to exclusion from the ordinary life of the society due to lack of resources, as spelt out for example in the particularly influential formulation by Townsend (1979). This has also been very influential from a policy-making perspective, as evidenced by the definition adopted by the European Economic Communities in the mid-1980s:

"The poor shall be taken to mean persons, families and groups of persons whose resources (material, cultural and social) are so limited as to exclude them from the minimum acceptable way of life in the Member State in which they live”.

Poverty from this starting-point has two core elements: it is about inability to participate, and this inability to participate is attributable to inadequate resources. Most economic research then employs income to distinguish the poor, with a great deal of research and debate on how best to establish an income cut-off for that purpose. There are also substantial theoretical and empirical literatures on concepts such as social exclusion (see for example Kronauer, 1998) and on the 'capabilities' approach pioneered by Sen (see for example 1980, 1993), which have implications for how one thinks about and measures poverty. Indeed, a concern with 'poverty’ per se may be seen as predominantly an Anglo-Saxon concern, with concepts such as deprivation and social exclusion more often the focus in countries such as France or Germany and with the 'level of living' approach to living standards and wellbeing of central importance in the Nordic countries (and having much in common with Sen's capabilities approach in general orientation, on which see for example Erikson, 1993).

In comparative analysis, the most common approach to deriving income thresholds has been to calculate them as proportions of median income in the country in question, with $50 \%$ or $60 \%$ of the median the most widely used. The underlying rationale is that those falling more than a certain 'distance' below the average or normal income in their society are unlikely to be able to participate fully in it, and notable examples from a very large literature 
adopting this approach are Atkinson, Rainwater and Smeeding (1995) and the OECD's recent studies Growing Unequal? (2008) and Divided We Stand (2011). Such research, like that on income inequality, was for many years bedevilled by differences in definition and measures in the data available for different countries, but sources such as the Luxembourg Income Study (LIS) micro-database, the figures produced by Eurostat from micro-data for the EU countries, and the database of aggregate poverty (and inequality) estimates assembled by the OECD have greatly improved this situation. Differences across countries and trends over time in relative income poverty measured in this fashion have played a central role in European research and policy debate, and Chapter 9 in the present volume by Morelli, Smeeding and Thompson presents evidence on trends in such measures to which we will return below. $^{2}$

This approach to deriving income thresholds can be contrasted with the USA, where the existence of a long-standing official poverty line has fundamentally influenced how poverty is debated and research carried out. That standard goes back to the 1960s, when it was originally based on the cost of a nutritionally adequate diet, multiplied by a factor to take account of non-food spending, but its key feature is that it has subsequently been up-rated in line with consumer prices, rather than linked to average income or living standards. To characterise this contrast as between "relative" versus "absolute" notions of poverty would be to over-simplify, since above subsistence level notions of what constitutes poverty inevitably reflect prevailing norms and expectations. The key issue in making comparisons over time is whether the poverty standard is fixed in terms of purchasing power - 'anchored' at a point in time - or increases as average living standards rise. As Lampman (1971) put it in a US context, in fighting a "War on Poverty" one may want to monitor how well one is doing in meeting a fixed target rather than redefining the target as income changes. However, over any prolonged period where average living standards are rising, this may lose touch with the everyday understanding of poverty in the society. Thus an influential expert panel reviewing the US official measure saw poverty in terms of insufficient resources for basic living needs, “defined appropriately for the United States today” (Citro and Michael, 1995).

The fact that the "anchored" measure has continued to be seen as relevant in the USA - for all its well-recognized and analysed technical limitations - is in itself thus a reflection of the fact that growth in median real incomes has been modest there. In Europe, the set of

\footnotetext{
${ }^{2}$ Many different ways of establishing such a threshold have been proposed, for example by reference to what it costs to buy a specified basket of goods and services, to ordinary expenditure patterns, to standards implicit in social security support rates, or to views in the population about for example the income needed to "get by".
} 
poverty and social inclusion indicators adopted by the EU since 2001 have supplemented purely relative income poverty thresholds with ones anchored at a point in time some years earlier and up-rated in line with prices. The onset of economic crisis from 2007-8, when median income and thus relative income thresholds actually fell in some countries, proved a salutary reminder of the value of such anchored thresholds. Similar arguments apply in making comparisons across countries at rather different levels of average income: neither purely country-specific relative measures nor common thresholds tell the whole story with respect to poverty. In a European context this was brought to the fore by the accession to the EU in 2004 and 2007 of new eastern countries with much lower levels of average income than the 'old' member states.

Alternative ways of establishing an income poverty threshold in a rich country have been proposed, for example by reference to what it costs to buy a specified basket of goods and services, to ordinary expenditure patterns, to standards implicit in social security support rates, or to views in the population about for example the income needed to "get by". This continues to represent a significant theme in poverty research literature, as shown by recent attempts to apply the 'basket of goods' approach in a consistent fashion across a variety of European countries (for a discussion of strengths and limitations of these alternatives see Nolan and Whelan, 1996). However, the extent to which this research has impacted on policy formulation and debate remains quite limited, with the relative and anchored income lines dominating, one suspects not least because of their reasonably straightforward empirical derivation.

In a similar vein, the way household size and composition are taken into account in applying those income lines is for the most part rather straightforward. The household is conventionally taken as the income recipient unit, as in the study of income inequality more broadly, assuming that income is shared so members reach a common standard of living. The fact that the types of household identified as poor (much more than the overall poverty rate) can be highly sensitive to the precise equivalence scale employed has been known for some time (see for example Buhmann et al., 1987, Coulter, Cowell and Jenkins, 1992), but in the absence of a more satisfactory alternative emerging from research practice is to rely on several commonly-used scales (the square root of household size, the 'OECD' scale, and the 'modified OECD scale) and (at best) present result with more than one so that this sensitivity can be assessed. While a number of studies have sought to open up the household 'black box' from a poverty perspective - a sub-set of the research on intra-household inequality more broadly discussed in Chapter 17 of the present volume by Chiappori and Meghir - this has had little impact on practice in empirical analysis and policy formulation. 
The same could be said of the extensive literature on how best to capture the extent of poverty in a single summary indicator, where despite the considerable literature developing sophisticated indicators the most commonly-used measure remains the simple headcount. Amartya Sen highlighted as long ago as the mid-1970s how this faces the policy-maker with the perverse incentive to target the least poor, and his (1976) and alternative ways of incorporating the "poverty gap” and inequality among the poor have been debated, often derived from a set of axioms representing a priori notions of the properties such a measure should have. The Foster, Greer and Thorbecke (1984) class of poverty measures, for example, are additively decomposable and, additionally, allow for different judgements regarding the importance attached to the extent on inequality among the poor. Such poverty measures that capture poverty intensity also suffer from greater sensitivity to measurement error, though, especially the presence of extreme low incomes which often reflects misreporting, ${ }^{3}$ and as Myles (2000) argues their mathematical representation may have made their meaning obscure to potential users. The robustness of poverty orderings has also been a long-standing concern in the literature (Atkinson, 1987; Zheng, 2000), and dominance approaches developed for income inequality comparisons have been the adapted for use in the poverty context (for a recent example see Duclos and Makdissi (2005), but once again this has not entered mainstream empirical practice, where the comparison of poverty headcounts over time or across countries on the basis of one or at most a very limited set of thresholds and equivalence scales remains the norm. An awareness of the importance of measurement error and the need to take statistical confidence intervals seriously in such comparisons does appear to be increasing, however (see for example Goedeme, 2013). There have also been significant improvements in the quality and comparability of income data for poverty analysis in recent years (as is the case for the analysis of income inequality more generally, as brought out in Morelli, Smeeding and Thompson's chapter 9 and in Toth, 2014), not least due to the efforts of organisations such as the OECD, the Luxembourg Income Study, and Eurostat as well as national statistics offices.

A substantial strand in recent research on poverty which is increasingly influencing practice has focused instead on questioning what economic research had tended to take for granted: that current income is the most satisfactory, or least bad, yardstick available for identifying the poor. It has instead been argued forcefully that low income fails in practice to

\footnotetext{
3 The poverty gap measure advanced by Hills (2002), based on the distance between the threshold and the median income of the poor, is one response to that problem.
} 
distinguish those experiencing poverty and exclusion, because current income does not capture the impact of savings, debt, previous spending on consumer durables, owneroccupied housing, goods and services provided by the State, work-related expenses such as transport and child-care, and geographical variation in prices, because needs also differ in ways missed by conventional equivalence scales (for example in relation to disability), and because income from self-employment, home production and capital are particularly difficult to measure accurately. One response is to measure financial poverty in terms of consumption rather than income, on the basis that the transitory component is a great deal smaller, but expenditure as measured in household budget surveys often covers only a short period and is not the same as consumption, while low expenditure may be associated with saving and does not necessarily capture constrained resources. Other avenues explored in research have been to impute income from durables, owner-occupied housing and non-cash benefits, to broaden the needs incorporated into equivalence scales, and to combine survey and other data to improve the measurement of income.

The exploitation of longitudinal data has also been a significant contributor to income-based poverty research. Poverty measures are often based on the income of the household in a specific week, month or year, but (even if measured accurately) income at a particular point in time may not be representative of the usual or longer-term income of the household. Longitudinal data tracking households and their incomes have now become much more widely available, allowing those who move in and out of low income to be distinguished from those who are persistently on low income, and a dynamic perspective on income now plays a central role in research on poverty. Bane and Ellwood (1986) pioneered research on the length of spells in poverty in the USA, and cross-country analysis was pioneered by Duncan et al. (1993). Comparative studies of income poverty dynamics since then include OECD (2001), Whelan et al. (2003), Fouarge and Layte (2005) and Valletta (2006). Movements in and out of poverty are special cases of more general income mobility, discussed in Chapter 11 by Jäntti and Jenkins in this volume. Available studies show what the OECD (2001) has summarised as the seeming paradox that poverty is simultaneously fluid and characterised by long-term traps. Many spells in poverty are short and represent only transitory set-backs, and considerably fewer people are continually poor for an extended period of time than are observed in poverty at a point in time, but on the other hand the typical year spent in poverty is lived by someone who experiences multiple years of poverty; comparison across countries has found poverty persistence to be particularly high in the USA and much lower in countries with lower cross-sectional poverty rates. The EU's social 
inclusion indicators now include a measure of persistent poverty, the percentage below the relative poverty threshold in the current year and at least two of the previous three. More generally, this aspect of poverty research, with its emphasis on trying to understand not only once-off poverty entries and escapes but also the cumulative experience of poverty over years, has had a major impact on the way policy effectiveness is thought about and assessed.

As well as broadening the measurement of income/financial resources and their dynamics, a parallel development in recent poverty research has sought to go beyond income, with a view to:

- identifying the poor more accurately and understanding the causal processes at work,

- capturing the multidimensional nature of poverty, and/or

- encompassing social exclusion conceived as something broader than "financial poverty”.

Non-monetary indicators of deprivation have been used for quite some time to directly capture different aspects of living standards and social exclusion (either on their own or combined with low income), to validate an income poverty threshold, and/or to bring out graphically what it means to be poor; the review of the literature on measures of material deprivation in OECD countries by Boarini and Mira d'Ercole, (2006) listed over a hundred studies. Over the past decade or more, non-monetary indicators measured at micro-level are also increasingly being used in order to capture the multidimensional nature of poverty and of social exclusion more broadly - especially in Europe, where the concepts of social exclusion and social inclusion have come to be widely used alongside poverty in research and policy circles, unlike the USA where they have so far had little purchase. Comparative analysis of datasets such as the European Community Household Panel Survey (ECHP) organised by Eurostat and carried out in most of the (then) EU member states from the mid-1990s to 2001, and the EU-Statistics on Income and Living Conditions (EU-SILC) data-gathering framework which replaced it, has identified distinct dimensions of disadvantage (see for example Whelan et al. 2001; Eurostat, 2005; Guio and Macquet, 2007; Guio, 2009; Nolan and Whelan, 2010, 2011), bringing out that low income alone is not enough to predict who experiences poor housing, neighbourhood deprivation, poor health and access to health services, and low education. The measurement of multi-dimensional poverty and inequality, discussed in Chapter 4 of this volume by Aaberge and Brandolini, raises complex issues not only about the best way to identify and empirically capture particular dimensions, but also 
how information about different aspects of deprivation or exclusion is best summarised across those dimensions (on which see Tsui, 2002; Bourguignon and Chakravarty, 2002; Atkinson, 2003; Aaberge and Peluso, 2012).

The focus on multidimensionality has gone well beyond a purely academic concern to also influence the way poverty reduction targets have been framed, both nationally and at EU level. The national poverty reduction target adopted in Ireland in the 1990s, for example, was framed in terms of the combination of low income and 'basic' deprivation, and lively debates about how best to frame targets for child poverty in the UK have centred on the role of multidimensionality. Since 2001 the EU's Social Inclusion process has at its core a set of indicators designed to monitor progress and support mutual learning that is explicitly and designedly multidimensional, including but going beyond income-based poverty indicators, including indicators of material deprivation and housing deprivation (see Atkinson et al., 2002; Marlier et al., 2007; Nolan and Whelan, 2011) Chapter 3). Even more strikingly, when in 2010 the EU adopted the Europe 2020 strategy for jobs and growth, which for the first time included poverty reduction among its high-level targets, the target population for poverty reduction was identified as those:

- below the $60 \%$ of national median threshold relative income threshold, and/or;

- $\quad$ above the material deprivation threshold, and/or;

- $\quad$ in a jobless household.

A total of $23 \%$ of EU citizens were identified as 'at risk of poverty and social exclusion', as this was labelled, significantly more than the $16 \%$ below the 'headline' $60 \%$ of median relative income threshold, and EU leaders pledged to bring at least 20 million of these people out of poverty and exclusion by 2020. While once can readily criticise the logic and implications of this precise combination of elements (on which see Nolan and Whelan, 2011, 2012), it represents a powerful illustration of the role which multidimensional measures, and direct measures of material deprivation as a central component, have come to play in framing European anti-poverty policy.

The European poverty target evolved from a process of development and adoption of social inclusion indicators at EU level over the previous decade (see for example Atkinson et al, 2002), which has had a significant influence on data and analyses of poverty and anti-poverty policy in Europe, and indeed on the way poverty is thought about and research framed. This serves as an important example of the broader point that a good deal of research on poverty is carried out or sponsored by bodies - national or international - that have an interest in demonstrating that particular sets of policies or orientations towards anti-poverty strategy are or 
are likely to be successful. In a more subtle way, their perspectives will influence the data and indicators available to researchers and thus the analyses that can be readily undertaken. There have been enormous advances in the availability of accessible microdata in recent years, which has fundamentally influenced poverty research and helped to 'democratise' it, but the influence of national governments and international organisations remains substantial.

Finally, in discussing how poverty research is approached differences in disciplinary perspectives are also important. For example, researchers from an economics perspective are generally more comfortable with financial indicators of living standards and exclusion, and highlight the role of economic incentives in understanding and tackling poverty, whereas sociologists have often been more open to employing non-monetary measures, and highlight the role of social stratification and social context. Having said that, there has been significant blurring of disciplinary boundaries and poverty research has become a site for particularly fruitful collaborations between inter alia economists, sociologists, social policy analysts, geographers, anthropologists, educationalists, epidemiologists, psychologists, and indeed geneticists and neuroscientists, of which this review chapter can only give a flavour, concentrating for the most part on the economics literature.

\subsection{Key Patterns and Trends}

As the previous section has highlighted, the most common practice in comparative research on poverty remains the application of relative income poverty thresholds and comparisons of headcounts of the proportions falling below those thresholds in different countries. On that basis poverty rates for various OECD countries based on the data in the Luxembourg Income Study (LIS) have been compared in for example Atkinson, Rainwater and Smeeding (1995), Fritzell and Ritakallio (2004), the OECD has assembled estimates for many of its member countries at intervals from 1980 which have underpinned its important studies in this area (notably OECD 2008, 2011), and annual estimates are also now produced by Eurostat for all the member states of the EU. This, together with national data, provides a substantially improved evidence base for the study of poverty across countries and over time.

Chapter 9 in this volume by Morelli, Smeeding and Thompson summarises broad trends in relative income poverty over time, with figures from the LIS suggesting that from the mid-1980s to mid-2000s relative income rates generally rose or stayed stable, with very few examples of significant falls. The OECD's analysis of the estimates of relative income poverty it assembled, as examined in Burniaux et al. (1998), Forster and Pearson (2002), 
Förster and d'Ercole (2005), Growing Unequal? (2008) and Divided We Stand (2011), highlighted that the most common direction of change in those figures was upwards. The corresponding data produced by Eurostat covers only (most of) the countries in the EU-15 for the period from the mid-1990s to 2001, based on the ECHP, while the expansion of the Union to 27 member states was accompanied by the development of a new statistical apparatus underpinning these estimates, EU-SILC, from about 2004; this means that trends before 2004 can be assessed only for the 'old' member states and, for many of these, with a break in the series in the early 2000s which affects comparability. None the less, the feature displayed by these figures highlighted by a number of studies is the disappointing progress in bringing relative income poverty rates down despite strong growth in employment in some countries over the decade to the mid-2000s (see for example Cantillon, 2011).

It is important to note however that there is considerable variability in country experiences and that the stability in the overall poverty rate can mask major underlying shifts for different groups. The OECD's studies, for example, show that the trend in relative income poverty for working age people in the second half of the 1990s and into the 2000s was generally upwards, often reflecting a decline in the poverty-reducing impact of taxes and transfers, but pensioners saw sizeable declines in many countries. So policies operating with respect to one important target group - such as older persons - could be having substantial success in reducing poverty while that is obscured by the impact of changes for other groups. In a similar vein, child poverty - the focus of particular attention from policy-makers in recent years - may not necessarily move in the same direction as the overall poverty rate, with the UK providing an example where trends in child versus overall poverty have deviated substantially over the past two decades.

The OECD has also usefully documented trends in overall poverty taking a threshold "anchored" at $50 \%$ of the median in the mid-1980s and then indexed to price changes. On this measure, all OECD countries achieved significant reductions in 'absolute' poverty up to 2000. In countries like Ireland and Spain, which experienced very rapid income growth, poverty in 1995 measured this way was one-sixth the level of 10 years earlier. The US poverty rate on this basis shows a decline from the mid-1980s up until 2000, though smaller than the average decline of the 15 OECD countries included in the study (Förster and d'Ercole, 2005). In a similar vein, it is striking that some countries where relative income poverty remained quite stable or even rose have seen very marked falls in levels of material deprivation, notably some of the lower-income countries joining the EU from 2004 as the common indicators of material deprivation now also produced by Eurostat serve to 
demonstrate. The evolution of alternative measures of poverty since the onset of the economic crisis across the OECD from 2007-08 is also of central relevance, as we discuss in detail in the final Section of this chapter.

National studies for various countries also shed light on poverty trends and the factors at work, though given differences in methods and approaches it is more difficult to generalise from them. In the USA, for example, most analyses of long-term poverty trends focus on the official poverty rate, which is not linked to average or median income (see for example Page and Stevens, 2006; Meyer and Wallace, 2009; Smeeding and Thompson, 2013). This (and variants of it) was higher in the 1980s than the 1970s but despite subsequent falls was still as high in the mid-2000s as it had been in the mid-1970s. Stagnant median wage growth, rising inequality and the evolution of unemployment have been highlighted in studies, with the changing wage distribution assigned a central role in explaining poverty trends. Studies of poverty trends in the UK, by contrast, have generally focused on relative income poverty and have highlighted the role of changes in the transfer and direct tax systems in the increase recorded in the 1980s and into the 19990s and then stabilisation from the late 1990s. However, as Dickens and Ellwood (2003) emphasise in a comparative study of Britain and the United States, the factors influencing poverty trends can differ substantially between absolute and relative measures as well as countries and it is hazardous to generalise.

Trends in poverty over time, overall and for specific sub-groups, offer one important window into the causal factors involved and into 'what works' in addressing poverty, especially in terms of the impact of changes made in social protection and tax systems. It is also striking, though, that the ranking of countries in terms of relative income poverty rates tends to be fairly stable over time. Table 1 shows the percentage of persons in households falling below $50 \%$ and $60 \%$ of median (equivalised) disposable household income in 25 OECD countries around the mid-2000s. The simple fact that there is very considerable crosscountry variation in poverty measured this way - with some countries displaying percentages below $60 \%$ of the median as low as $11-12 \%$ and at the other extreme countries having figures twice that high - and that the ranking of countries tends to be reasonable stable over time suggests that there are important structural factors at work from which anti-poverty strategies have much to learn.

[Table 1. Income Poverty Rates in OECD Countries, Mid-2000s] 
A similar point is brought home by reference to the variation across countries in relative income poverty rates for specific population sub-groups. Table 2 illustrates this with the rates for children and older persons falling below $50 \%$ of national median income, compared with the population as a whole. Children have above-average rates in about half the countries shown, with the gap being particularly wide in the UK and the USA, but in a substantial minority their rate is below average. The elderly have an above-average rate in most countries, with substantial variation in the size of the gap, and there are some where their rate is well below the average. A similar comparison across the EU 27 using data from EU-SILC shows similar patterns. So this reinforces the notion that there is much to be learned in policy terms from analysis of the situation and treatment of similar groups in different countries.

\section{[Table 2. Income Poverty Rates for Children and Elderly in OECD Countries, Mid-2000s]}

The same is true of other groups which are generally thought of as vulnerable. For example, the unemployed face a significantly heightened risk of relative income poverty virtually everywhere, but the gap between them and the employed varies widely across countries. Similarly, lone parents often face much higher risks of poverty than couples with one or two children, but that gap varies a great deal. As OECD (2005) points out, in many countries it is not living a single-parent households per se that increases risk, but rather the likelihood that parent is not in work. As we shall see, this type of comparative analysis plays a central role in research aimed at informing anti-poverty policies and strategies.

It is also worth noting that although relative income poverty measures are sometimes dismissed as really only capturing inequality, in fact a country (or group within it) can have zero poverty despite substantial inequality. To give concrete examples, in both the Netherlands and New Zealand the incidence of relative poverty among the elderly (with the 50 per cent of median threshold) is close to zero, although there is very substantial income inequality among their elderly populations. The redistributive effort required to truncate the distribution at a widely used poverty threshold like 50 per cent of median equivalent income is in fact a fraction of the actual redistributive flows that take place in most countries. In practice, as Figure 1 shows, broadly speaking where inequality in disposable income is high then relative income poverty rates tend to be high as well, but similar inequality levels can be associated with quite different levels of relative income poverty. 


\subsection{The Welfare State and Poverty}

As Barr (2001) puts it, the welfare state combines the role of piggy bank and Robin Hood, providing collective insurance against social risks while also aiming to ameliorate need and poverty. Redistribution can be horizontal, across the life cycle, or vertical between higher and lower incomes. Poverty reduction is by no means the sole criterion against which the success of Welfare State institutions would or should be judged - whether at a point in time or over the life-cycle - but it would be widely accepted as among the core aims. Research aimed at assessing success or failure in those terms can focus at the aggregate level, at specific population sub-groups, or at particular institutional structures, interventions or innovations, and can be for a particular country or from a comparative perspective.

The nature of that research is also multi-faceted. At one end of the spectrum one can locate studies of the effectiveness of very particular aspects of institutional structures or changes in those structures on the target population to whom they are directed. Such evaluation studies employ a wide variety of analytical and technical approaches, which have been the subject of intensive development in the economics literature in recent years. While the outcome studied is occasionally whether people are lifted out of poverty, there is a much more extensive literature focusing on effectiveness in getting unemployed persons into employment, improving performance in school, keeping people out of jail or improving their health, all of which may be expected to impact on poverty status. While randomized controlled trials are recently in vogue in this context - though the negative income tax experiments conducted in the USA and Canada in the 1970s provide early large-scale examples ${ }^{4}$ - more commonly assessments are not based on such an approach. The methods employed include reduced form or limited information models (including least squares, matching methods including propensity score matching, instrumental variable analysis or the closely related regression discontinuity design approach, and difference in difference estimation) versus the estimation of structural models/parameters. ${ }^{5}$ Such methods are discussed extensively in other Handbooks in this series (notably those focused on labour economics, since assessing the impact of labour market programmes has been a particularly

\footnotetext{
${ }_{5}^{4}$ See for example Levine et al. (2005).

5 For discussion of the advantages and disadvantages of alternative approaches see Chetty (2009), Deaton (2010), Heckman and Urzua (2010), Imbens (2010) and Heckman (2010).
} 
fertile field of application); purely from the point of view of research on poverty, though, while influencing specific national reform efforts they have had much less impact on the way anti-poverty policy is thought about more broadly.

In that respect, comparative analysis of poverty outcomes and redistributive effort across countries over time continues to dominate. This is underpinned by the fact that the direct effect of transfers and direct taxes on measured poverty is seen to differ very substantially across countries. OECD analysis concludes that the best-performing countries succeed in lifting about two-thirds of their pre-tax/transfer poor above the threshold, while others only manage to move one-quarter above. Recent EU statistics tell a similar story, as Table 3 illustrates: welfare systems reduce the risk of poverty by $38 \%$ on average across the EU, but this impact varies from under $15 \%$ to over $60 \%$ across the member states. Some countries achieve better 'efficiency' (i.e. reduce poverty more for each euro or dollar spent) through targeting low-income groups, and the role of means-testing is one of the most hotlydebated aspects of anti-poverty policy, to which we return below. However, the prior point to be made here is that the pattern of incomes from the market, taken as the baseline for comparison, will itself be very much influenced by social transfers, and indeed by welfare state institutions more broadly. The existence of social transfers allows substantial numbers of households to have no income from the market, which would not be sustainable otherwise, and the welfare state also affects incentives to work and save in many other ways: the 'no welfare state' counter-factual is not known.

[Table 3. Income Poverty Rates Pre- and Post-Transfers in EU Countries, 2007]

A favoured mode of analysis in comparative studies is to take a set of countries - at a point in time or pooling cross-sections over time - and assess the relationship between poverty outcomes and a wide set of independent variables reflecting population structures, welfare spending levels and aspects of labour market and welfare state institutions. (These parallel, and sometimes overlap, similar studies employing income inequality as dependent variable reviewed in depth in Chapter 20 of the current volume by Forster and Tóth). Particularly influential studies in this vein include Korpi and Palme (1998), Moller et al (2003), Kenworthy (2011). In such comparative analysis countries may be taken as individual units of observation, or they may be grouped together into different "welfare regimes", designed to capture key commonalities/differences in welfare state institutions. EspingAndersen's (1990) distinction of three distinct regimes has been highly influential: the 
liberal/Anglo-Saxon countries with minimal public intervention and a preference for targeting and reliance on the market, the social democratic/Nordic countries with comprehensive social entitlements, and the Continental welfare states with conservative origins built around social insurance but often along narrowly defined occupational distinctions and a significant degree of reliance on the family (see also Esping-Andersen, 1999, 2009). A fourth 'Southern' regime is also generally distinguished (Ferrera, 1996), and the treatment of the formerly communist countries of eastern Europe is also a matter for debate - the relationship between aggregate social spending and poverty levels looks systematically different for the countries which joined the EU in 2004 versus the "old” 15 members (see for example Tsakloglou and Papadopoulos, 2002), but treating them as a single 'regime' may not be satisfactory. Many empirical studies have brought out the extent to which conventional indicators of (relative income) poverty vary systematically across welfare regimes (for a recent example see Whelan and Maitre, 2010), and highlight the consistently low rates found in Nordic countries compared with the generally high (though varying) ones seen in the liberal and southern European countries. Looking in some detail at the make-up of household income by source, Maitre, Nolan and Whelan (2010) show that countries in the anglo-saxon/liberal regime were distinctive in the extent to which low-income households were dependent on social transfers, and also in the extent to which that dependence served as a predictor of material deprivation. The social democratic and corporatist regimes were characterised by a more modest degree of welfare dependence among low-income households, while in the Southern Mediterranean countries welfare was not strongly associated with low income and was a particularly poor predictor of deprivation.

Aggregate-level comparative analysis of this type suggests that while transfer and tax systems are undoubtedly key in underpinning variations in poverty levels, other institutional features also contribute in the best performers, notably high levels of minimum wage protection and strong collective bargaining compressing wages, more extensive public and subsidized employment as well active labour market programmes, higher levels of public spending on education etc (see also Chapter 20 in this Handbook). Disentangling the effect of these various factors is inherently fraught with difficulties, and that is where simulation via tax-benefit models, discussed in detail in Chapter 26 of this volume by Figari, Paulus and Sutherland may be particularly helpful. The Euromod research programme in particular has enabled comparative tax-benefit simulation analysis across the EU (Immervoll et al., 2006, Figari and Sutherland, 2013) with major implications for policy. To take just one example, Cantillon et al. (2003) showed that simply increasing spending on transfers would have a 
limited impact on poverty in some EU countries because much of it would go to those already above the poverty line, particularly in the Southern European welfare states where pensions dominate.

Another central strand of comparative poverty research has focused on analysis of the characteristics associated with being in poverty and the underlying processes involved, employing micro-data. This has been the subject of a very wide variety of studies covering many countries, both descriptive and econometric. Broadly speaking, the types of individual or household seen as at particular risk of poverty include those with low levels of education and skills, the low paid, the unemployed, people with disabilities, lone parents, large families, the elderly, children, ethnic minorities, migrants, and refugees. However, there is substantial variation across countries in the patterning of risk, with major implications for how the underlying processes are understood and for policy. The extent to which individual characteristics, qualifications or experiences manifest themselves in high poverty rates is clearly seen to depend on the household, labour market and institutional settings in which those "disadvantages" are experienced. To take one example, the poverty risk for the unemployed compared with others is seen to depend on whether they have dependants, whether there are others in the household at work, and how the welfare state and its institutions try to cushion the impact of unemployment, most importantly through social protection. Strikingly, a high employment rate is clearly not a sufficient condition for low poverty among the working aged population, which as we discuss below is of central relevance when boosting labour market participation is at the heart of anti-poverty policy in many countries.

Finally, the availability of longitudinal data has also allowed the development of econometric modelling of poverty dynamics, which seeks to link observed movements into or out of poverty over time to changes in the earnings, labour force participation and composition of the household; Duncan et al. (1993) was the first to do so in a comparative setting. A distinction is often made in such dynamic analyses between income "events", such as changes in earnings or benefits, and demographic "events" such as the arrival of a new child, partnership formation, death, marital dissolution, or offspring leaving home. The comparative dynamic analysis by OECD (2005) suggests that changes in household structure may be less important in poverty entries and escapes in European countries than in the USA, with changes in transfers as well as earnings seen to be important in the EU and to a lesser extent in Canada, but much less so in the USA. 


\section{Section 2: Social Protection and Redistribution}

\subsection{Introduction}

Cash spending as a percentage of GDP is the most widely used measure of how much "effort" is being made to directly redistribute income. Despite its widespread use, this measure has some well documented shortcomings. First, it ignores the need to jointly analyze benefit and tax policies. Conventional measures of (gross) social expenditure tend to overestimate the cost of welfare in Denmark, Finland and Sweden, where a substantial amount of benefit spending is clawed back through taxation. Conversely, in the Czech Republic and Slovenia, a substantial share of social spending takes the form of tax breaks for social purposes rather than cash transfers (Adema et al., 2011). Another widely acknowledged weakness of this measure is that is a very imperfect indicator of policy intent and policy design. A high level of spending may result from very generous benefits flowing to small numbers of people, and not necessarily people occupying the bottom end of the distribution, for example government elites. Yet it may also result from relatively small benefits flowing to a large number of people (De Deken and Kittel, 2007).

And yet several studies have established a strong empirical relationship at country level between the overall level of social spending and various measures of inequality and inequality reduction, including (relative) poverty. This is arguably one of the more robust findings of comparative poverty research over the past decades (Atkinson, Rainwater and Smeeding, 1995; Ferrarini and Nelson, 2003; Gottschalk and Smeeding, 1997; 2000; Nolan and Marx, 2009; Pestieau, 2006; Kenworthy, 2004; 2008; 2011; Kraus, 2004; OECD, 2008; Immervoll and Richardson, 2012). Notable in these analyses was that no advanced economy achieved a low level of inequality and/or relative income poverty with a low level of social spending, regardless of how well that country performed on other dimensions that matter for poverty, notably employment. Vice versa, countries with relatively high social spending tended to have lower inequality and poverty. Here the extent of cross-country variation was always more significant, with some countries achieving more limited inequality/poverty reductions despite high social spending.

There number of countries for which internationally comparative data are available has increased over recent years recently. As Figure 2 shows, there are now a number of countries (the Czech Republic, Slovakia and Slovenia, as well as Korea) that do combine fairly low levels of social expenditure with low relative poverty rates and income inequality. For the Central European countries, part of the explanation may lie in a reliance on tax breaks as 
social policy tools, which are not captured in gross social spending indicators. More generally, the redistributive impact of taxes is not captured here (Verbist, 2004; Verbist and Figari, 2014).

[Figure 2. Cash public social expenditure and income inequality on working age, late 2000s]

This relatively strong relationship between social spending and poverty at the country level probably does not simply reflect the direct impact of transfers only: high-spending countries have other institutional features that contribute, notably high levels of minimum wage protection and strong collective bargaining compressing wages (hence limiting overall inequality), more extensive public and subsidized employment as well active labour market programmes, higher levels of public spending on education etc. Disentangling the effect of these various factors is inherently fraught with difficulties. There may in fact be mechanisms of mutual reinforcement between these factors (Beramendi, 2001). Barth and Moene (2009) argue that a more equal wage distribution leads to welfare generosity through a process of political competition. In turn, more income redistribution produces more equality. The authors hypothesize that this 'equality multiplier' operates mainly through the bottom of the income distribution: the amplification occurs where wages near the bottom of the distribution are compressed, not where higher incomes are compressed. They find empirical support in their analyses on 18 OECD countries over the years 1976 to $2002{ }^{6}$

While in theory low or moderate levels of social spending could produce low poverty rates if resources were well-targeted, the reality remains that almost no advanced economy achieves a low (relative) poverty rate, or a high level of redistribution, with a low level of social spending. Large, universal welfare systems, while on paper being least distributive,

\footnotetext{
${ }^{6}$ There is a sizeable political economy literature on this issue. McCarty and Pontusson (2009) review a number of political economy theories with regard to voter behaviour under different conditions of economic inequality. The so-called median voter models assume that changes in the income distribution lead to a shift in the preference of the median voter, or the 'political middle'. Moene and Wallerstein $(2001,2003)$ argue that under conditions of rising income inequality, the median voter has a preference for reduced expenditure on insurance and social spending. Earlier Meltzer and Richard (1981) formulated an opposing hypothesis, predicting that rising income inequality leads to a shift in preferences of the median voter towards more redistribution. The evidence is quite mixed. Kenworthy and Pontusson (2005) find empirical support for the Meltzer and Richard thesis. Milanovic (2000) finds a consistent association between gross household income inequality and more tax/transfer redistribution in a set of 24 democracies in the period of the mid seventies-mid nineties. More recently Olivera (2012), performing an analysis on a pool of 33 European countries, finds that inequality increases the demand for redistribution and that increases in income inequality stimulate the demand for redistribution. Yet the empirical evidence varies and some studies arrive at opposite conclusions (Iversen and Soskice 2006, 2009; Finseraas 2009; McCarty and Pontusson 2009; Lupu and Pontusson 2011; Toth, Horn and Medgyesi 2013).
} 
distribute in fact the most. Systems that by design strongly target resources to towards the poorest tend to be in fact less redistributive. Korpi and Palme (1998) have called this the 'paradox of redistribution'.

There is a long-standing controversy in welfare state literature over the question of whether targeting benefits towards the bottom part of the income distribution actually enhances the redistributive impact of welfare state policies, especially of social transfer policies. This issue is of far more than academic importance. In its 2011 Divided We Stand?, the OECD states that "redistribution strategies based on government transfers and taxes alone would be neither effective nor financially sustainable”. In this context the OECD (2011) calls for “well-targeted income support policies”. Organisations like the IMF and the World Bank have long advocated targeted benefits. The issue of targeting will probably gain even more poignancy in a post-crisis period marked by continued and in some cases increased budget austerity.

The debate on targeting is still marked by opposed views. On the one side there are those who belief that a welfare state can only fight poverty effectively and efficiently (i.e. cost-effectively) when benefits are mainly targeted to those most in need, i.e. when benefits are selective. The straightforward argument here is that selective benefit systems are cheaper because fewer resources are 'wasted' on people who are not poor. Lower public expenditures imply lower taxes, which in turn are said to be conducive to economic growth. Economic growth, the argument proceeds, benefits the poor directly (although not necessarily proportionally so) and increases at the same time the fiscal base for redistributive policies.

This view of selectivity has never been commonly shared. Two sorts of arguments underpin this more critical stance. First, there are technical considerations. Van Oorschot (2002) sums up the most important dysfunctions of means-testing. First, these include higher administrative costs. Establishing need or other relevant criteria require monitoring, whereas universal benefits allow for less complex eligibility procedures. Furthermore, means tested benefits are subject to higher non-take up, partly because of stigmatization issues. Finally, and perhaps most importantly, targeted benefits can give rise to poverty traps, where benefit recipients have little incentive to take up work because this would entail loss of benefits.

A second line of counter-argument is that proponents of selectivity pursue a 'mechanical' economic argument that makes abstraction of the political processes which determine how much is actually available for redistribution. The reasoning is that, paradoxically, in countries with selective welfare systems fewer resources tend to be available for redistribution because there is less widespread and less robust political support 
for redistribution. As a consequence, the redistributive impact of such systems tends to be smaller. To put it differently: some degree of redistributive “inefficiency” (the Mattheweffect) is said to foster wider and more robust political support for redistribution, including to the most needy. This follows from the fact that a universal welfare state creates a structural coalition of interests between the least well-off and the politically more powerful middle classes (median voter theorem). By contrast, a selective system entails an inherent conflict between the least well-off, by definition the sole recipients of social transfers, and the better off, who fund the system without the prospect of getting much out of it.

The juxtaposition outlined above forms the starting point for Korpi and Palme's highly influential 'Paradox of Redistribution', a paper in which they claim that more selective systems, paradoxically, have a smaller redistributive impact than universal systems offering both minimum income protection as well as income security and cost compensations (for children) in a broader sense. Korpi and Palme (1998) find that, in effect, this relationship is mediated by the relative size of available means for redistribution. Countries with selective redistribution systems, they argue, spend less on redistribution, at least in the public sector. In essence, selective systems are generally smaller systems.

The degree of redistribution is measured here by comparing the actually observed income inequality or at-risk-of-poverty rate with a rather unsophisticated 'counterfactual' distribution (Bergh, 2005). In theory this counterfactual ought to accurately reflect the income distribution that would prevail in the absence of social transfers. However, the construction of this counterfactual is hampered by theoretical and practical problems. In most cases, including in Korpi and Palme's paper, pre-transfer income is simply calculated by deducting observed social transfers and re-adding observed taxes. Full abstraction is thus made of any behavioural effects which a change in tranfer/tax regime would entail. While patently less than perfect, the reality is that no satisfactory method exists to adequately model such behavioural effects. Many studies have pursued similar empirical approaches, for example Nelson (2004; 2007).

Another critique has been formulated by Moene and Wallerstein (2003) who have argued that analyses of redistribution need to be done at a more disaggregated level than 'the welfare system' because the determining redistributive principles may differ substantially for, say, unemployment, health care or pensions. Some schemes may rest heavily on the insurance principle, while others may put more weight to the need-principle. Universality and selectivity can coexist within one system. Yet Moene and Wallerstein (2001) also conclude that universal provisions provoke the largest political support because of the higher chance of 
middle class citizens to become a beneficiary. Some opinion based studies also confirm that universal welfare schemes enjoy broader support (Kangas, 1995).

Some recent studies, however, claim that the link between redistribution and universal provision has substantially weakened, or even reversed over time. Kenworthy (2011) reproduces and updates Korpi and Palme's analyses, which related to the situation in 11 countries as of 1985. Kenworthy's findings confirm that countries with more universal benefits achieve more redistribution (measured in the size of redistributive policies in the budget) for the period 1980 to 1990. By 1995, the image becomes less clear. Data for 2000 and 2005 seem to indicate that there is no longer any association (either positive or negative) between the two variables. Evidently, the findings are based on a small number of cases, which make them particularly sensitive to outliers. A trend towards more targeting in Denmark, in conjunction with an evolution towards more universal benefits in the US, is largely responsible for the shift in conclusions. Moreover, the new findings may be driven to some extent by the growing share of pensions in social spending. Kenworthy (2011:58) writes about this: "This by no means settles the question, but it does suggest additional reason to rethink the notion that targeting is an impediment to effective redistribution.”

Figure 3, taken from Marx et al. (2013), strengthens the finding that the relationship between the extent of targeting and redistributive may have weakened considerably. Here targeting is captured through the concentration index. This is calculated in a similar way as the Gini coefficient. The more negative the concentration coefficient, the more targeted the transfers, whereas the closer the concentration coefficient is to the Gini, the more universal the transfers are distributed. Australia, the United Kingdom and Denmark have most negative concentration coefficients and can be characterized as strongly pro-poor. Negative concentration coefficients are found in the majority of the countries, pointing to a substantial degree of targeting. Note however that the term 'targeting' suggests that outcomes are due to the characteristics of the system, but this need not be the case. Moreover, the outcomes of a system are highly dependent on the characteristics of the underlying population, in terms of socio-demographic characteristics, income inequality, composition of income, etc. If, for instance, a benefit is designed in such a way that all children are eligible, but all children are situated in the bottom quintile, then this policy measure may appear as targeted in its outcomes, even though its design may not include any means-testing or needs-based characteristic. This means that strictly speaking we cannot derive from the concentration coefficient how pro-poorness of a transfer comes about. 
[Figure 3. Concentration index (ranking by gross income) and redistributive impact, mid 2000s]

Redistribution refers to the impact of taxes and transfers on income inequality. It is measured by the difference between the Gini coefficients with and without tax-transfers relative to pre-transfer income; this corresponds in this analysis to the difference of the Gini coefficients of market and disposable income relative to that of market income. The impact on inequality is driven by the size of transfers, as well as by their structure, i.e. whether these transfers are going relatively more to lower or higher incomes.

Looking more closely at this graph, at the left hand side are Australia, the United Kingdom and Denmark, all characterized by having benefit systems that are the most strongly pro-poor of all countries. Yet the redistributive impact in Denmark appears to be much stronger. Similarly, looking at the countries with still strong pro-poor spending (concentration indices between -0.2 and 0 ), the corresponding redistributive impact differs a great deal. Some of the countries with the strongest redistributive tax/transfer systems are to be found here (Sweden and Finland), together with some countries with the weakest (the USA, Canada, Israel and Switzerland). On the right hand side of the graph - the countries with positive targeting coefficients - the relationship does become consistently negative, especially in the countries with the weakest pro-poor spending (Greece, Spain and Italy).

Why does a similar degree of strong targeting, as captured by the concentration index, produce stronger redistributive outcomes in Denmark as compared to the UK and Australia? Similarly, why do similar (quasi)-universal systems yield such different redistributive outcomes across countries? This strongly suggests that design features matter. It is notable that one relationship remains fairly strong: the one between the extent of targeting and the size of the system. But there are exceptions here: a country like Denmark does combine a strong degree of targeting with a high level of social spending.

The strongest redistributive impact is achieved by countries that combine moderate (Sweden and Finland) to strong targeting (Denmark) with comparatively high levels of spending. This suggests that the most redistributive systems are characterized by what is called 'targeting within universalism”. That is to say: systems in which many people receive benefits but where the poorest get relatively more.

Yet it is interesting to note that the very strong relationship between the extent of targeting and the size of the spending has weakened, as is documented by Kenworthy (2011). One of the factors that arguably made targeted systems less politically robust and prone to 
spending cuts in the 1980s was the fact that strongly targeted (means-tested) benefits entailed strong work disincentives and also (perceived) family formation incentives. The last decades have seen an intensified attention to this issue. To reduce work disincentives, earnings disregards have been introduced for people who make a (partial) transition from complete benefit dependency to part-time work.

Most importantly, perhaps, means-tested benefits are no longer exclusively aimed at people not in work, but also at those in work in low-paid jobs. The French RSA (Revenu de Solidarité Active) scheme is a good example of a new style means-tested benefit scheme that offers integrated support for the non-employed and (part-time) low paid workers alike. The scheme also has entirely different work incentives. The RSA was introduced in France in 2008 the specific aim of remodelling the incentive structure social assistance beneficiaries, and particularly to make work or returning to education a more lucrative financial prospect. The previous minimum income system (Minimum Integration Income - RMI) was based on a one for one trade-off of benefit for earned income. Under RSA a 62\% slope is applied. Efforts have also been made to encourage beneficiaries of RSA into employment, for example with assisted employment contracts and (improved) insertion mechanisms. In addition, the RSA has simplified the provision of social protection by combining several previously separate schemes into a single sum. A household with no earned income is eligible for the "basic RSA" which is defined at the household level and takes into account the composition of the household. The "in-work RSA" acts as a top-up for people paid less than the national minimum wage (SMIC).

The point here is that targeted, means-tested systems look totally different today from the systems in place in the 1980s. Whereas the old systems were the focus of harsh welfare critiques, especially from the right, the new targeted systems are lauded as gateways of welfare to work. They enjoy broad partisan support, as is evident in the UK where the WTC, implemented by the Labour government, building on a scheme implemented under a Conservative one, is again expanded by the current Conservative one. Similarly, in France, the newly elected socialist government has no intentions for a major overhaul of the RSA, introduced by the Fillon/Sarkozy government.

In the United States, the Earned Income Tax Credit - a transfer program for households on low earnings - has become the country's pre-eminent welfare programme (Kenworthy, 2011). The system appears to enjoys far broader and more robust political support than earlier American anti-poverty programmes. The system also is less strongly targeted than earlier provisions and it caters to larger sections of the electorate, including the 
(lower) middle class, and this may account for that expansion. But an equally if not more important factor may well be the fact that the system is perceived to encourage and reward work.

\subsection{Cash Transfers for the Inactive Working-age Population}

Much comparative poverty research that has sought to link observed variation in income inequality and poverty across countries to policy has relied on government (social) spending statistics as indicators of policy 'effort'. As we have seen, the relationship across countries between the level of social spending as a percentage of GDP, or some related indicator, and observed inequality or poverty levels is in fact by and large a rather strong one. This is in a way surprising because the level of spending is as much reflective of the number of people receiving benefits than it is of the level and thus potential adequacy of those benefits. Likewise, measured outcomes, for example pre versus post transfer differences in inequality or poverty also depend on a host of factors that are independent or only indirectly influenced by policy: contextual and compositional factors, including labour market conditions (unemployment, employment patterns, wages), household composition (patterns of cohabitation, marriage, divorce, childbirth, ...), policies which influence these dynamics (e.g. ALMPs, child care,..)

If we want to understand variations in outcomes we need more sophisticated and accurate measures of policy effort and policy design than spending indicators. So-called institutional indicators aim to be directly reflective of policy intent and design. Replacement rates for various branches of social insurance are commonly applied indicators of social protection. They are intended to express the level of benefit generosity within a particular provision, for example unemployment or disability insurance. The OECD has been compiling such time series for a considerable length of time. Academic databases have been compiled by, among others, the Swedish Institute of Social Research (the SCIP database) and the University of Connecticut (Scruggs database).

While such indicators are more directly reflective than spending based measures of what actually happens at policy levels they are not without their drawbacks. One is that replacement rates are generally expressed as a proportion of a reference wage. This is problematic for various reasons. With the growth of part-time and temporary employment, it has, become increasingly difficult to specify a consistent wage denominator on the basis of available data. More importantly, wages have generally not evolved in line with the standard 
of living (and thus the relative poverty threshold). In many countries the standard of living has increased thanks to the proliferation of dual income families rather than through real wage growth. The mere fact that benefits follow wages says little about the potential adequacy of benefits in terms of poverty relief. A second important problem is that replacement rates, e.g. within the systems of unemployment insurance or invalidity, do not capture the entitlement criteria applied, nor do they adequately express the entitlement periods. Nonetheless, there are strong indications that these are precisely the areas where policymakers have intervened the most. Unemployment benefit entitlement, for example, is now linked more strongly with job-search intensity. A third important issue is that replacement rates are based on a narrow rationale and tend to be calculated on a purely individual basis. For example, unemployment benefits may be combined with (increased) child benefit and other allowances. Additionally, of course, there may be the income of other household members, including its impact on benefit entitlement and vice versa. Also relevant in this context is the role of taxation. In most instances, the level of income protection that people actually receive in various situations is determined by a complex interaction between social security, social assistance and taxation.

It is nevertheless interesting and relevant to consider trends. OECD time series on net replacement rates for the unemployed provide strong indications of reduced cash support for the unemployed between 1995 and 2005 (Immervoll and Richardson, 2011). Seven of the 10 countries recorded declining NRRs. Finland and Germany saw the biggest reductions in net replacement rates. Changes for the unemployed in most countries tended to be less damaging (or, sometimes, more beneficial) for families with children. The largest relative income drop was generally faced by long-term unemployed jobseekers who mostly rely on unemployment assistance or social assistance for income support.

In the remainder of this section we will focus in somewhat more detail on institutional indicators of minimum income protection because adequate protection against severe financial poverty is arguably the first duty of the welfare state and also because poverty relief is the prime focus of this chapter. Such a focus is further desirable because the design features of tax and benefits systems, and especially the way various programmes interact in specific situations, tend to be so complex that they are not accurately and validly captured in a limited number of parameters. Minimum income protection provisions also mark the ground floor of other income maintenance provisions; minimum social insurance levels and minimum wages are almost always above the level of the social safety net. In that sense 
indicators of minimum income protection also tell us something about the generosity of other income maintenance provisions.

We draw on the CSB Minimum Income Protection Indicators (MIPI) dataset. In this dataset net income packages are calculated using the so-called model family approach, where the income package of households in various situations (varying by household composition and income levels) in simulated, taking into account all relevant benefits for which such households are eligible and also taking into account taxes. The MIPI database is among the most comprehensive data bases available in terms of geographic and longitudinal scope, as well as in terms of the range of household situations and income components. It is worth pointing out that such institutional indicators have their limits too. They are calculated for a limited number of family types and situations. The assumption is that there is full take up of benefits and that people effectively and immediately receive what they are entitled to. In the case of minimum wages the assumption is these are fully enforced. However, this is not always the case and this is one reason why the observed relationship between generosity levels as reflected in these indicators and outcomes is relatively weak.

Van Mechelen and Marchal (2013) have analyzed patterns and trends in the level of minimum income protection for able bodied citizens in the European countries. The chief focus is on means-tested benefits providing minimum income protection, usually in the form of social assistance. These general means-tested benefits provide cash benefits for all or almost all people below a specified minimum income level. In some countries separate schemes exist for such groups as newly arrived migrants or the disabled. The empirical analyses use data from the CSB-Minimum Income Protection Indicators dataset (CSB-MIPI) and cover social assistance developments in 25 European countries and three US States. The study shows that the minimum income benefit packages for the able bodied in Europe have become increasingly inadequate in providing income levels sufficient to raise households above the EU at-risk-of poverty rate, defined as 60 per cent of median equivalent income in each country (Figure 4). The overall tendency for 1990s was one of almost uniform erosion of benefit levels, relative to the development of wages. This downward trend in the relative income position of families in receipt of social assistance changes somewhat in the 2000s, when the erosion of the level of benefit packages came to a halt in a number of countries. In a few countries there is even evidence of a partial reversal of the declining trend, thus somewhat strengthening the income position of able bodied persons that are in receipt of social assistance benefits. During the crisis period in particular a small number of countries have taken took extra steps to increase protection levels (Marchal, Marx and Van Mechelen, 
2014). Despite a number of positive developments, net incomes of minimum income recipients continue to fall well short of the EU's at risk of poverty threshold in all but a few EU countries. The size of the gap between the level of the social safety net and the poverty threshold varies across countries and family types, but it is generally quite substantial.

[Figure 4. Net minimum income packages, 2009, EU Member States]

While the erosion of minimum income protection levels seems to have slowed the fact remains that Europe's final safety nets offer inadequate protection in all but a handful of countries. This begs the question: why are social safety nets not more adequate? Let us briefly consider two potential impediments: first, "adequate social safety nets are not affordable” and second, “adequate social safety nets undermine the work ethic and people's willingness to work”.

Are adequate social safety nets too costly? Final safety net provisions (social assistance schemes) generally constitute only a fraction of total social transfer spending (typically well below 2.5 percent of GDP in Europe, except in Ireland and the UK), the bulk of outlays going to pensions, unemployment and disability insurance, child benefits and other benefits. Vandenbroucke et al. (2013) have made tentative calculations showing that the redistributive effort required to lift all equivalent household incomes to the $60 \%$ level would be below 2.5 per cent of aggregate household income in most European countries and nowhere higher than 3.5 per cent. The countries that would have to make such a relatively great effort are all Southern and Eastern Member States. Vandenbroucke et al. (2013) also show that it is not the case that being poor in GDP per capita always implies a great redistributive effort to close the poverty gap: the Czech Republic and Hungary are relatively poor in terms of GDP per capita, but closing the poverty gap would require relatively little effort. On the other hand, Denmark and the UK have much higher living standards, yet they would have to make a relatively sizeable effort to close the poverty gap. Such a mechanical calculation ignores incentive effects and behavioural change (more poor people may prefer social assistance to low-paid jobs; the non-poor may reduce their work effort). The real cost of such an operation is probably higher than the mechanical effect and the calculation may be seen as indicating a lower boundary for the distributive effort that is required. Still, the calculation also illustrates that the cost of an adequate social safety net is not necessarily outside of the realm of the conceivable. 
Are adequate social safety nets compatible with work incentives? Despite widespread and sometimes strongly worded concerns over the potential work disincentive effects of social safety nets empirical studies tell a more nuanced story (Immervoll, 2012). The income gap between situation of full-time dependence on minimum income benefits and a full-time job at the minimum wage (or the lowest prevailing wage) is in fact quite substantial in most European countries, especially for single persons. In some countries and under certain circumstances particular groups like lone parents with young children gain relatively little from moving into a low-paid job, especially when child care costs are accounted for. Partial transitions into work - moving to a small part-time job - also do not pay in certain circumstances. But generally speaking it is hard to argue that long-term dependence on social assistance benefits is an attractive financial proposition in most of Europe. The hypothetical Europe-wide introduction of social assistance minimums equal to $60 \%$ of median income would however create a financial inactivity trap in many countries, as is also brought out by the paper by Vandenbroucke et al. (2013). In countries like Bulgaria, Estonia, Slovenia and Lithuania, the net income of a single benefit recipient would be between $25 \%$ and $30 \%$ higher than the equivalent income of a single person working at minimum wage; in Spain and the Czech Republic, the relative advantage of the benefit claimant would amount to around 15 per cent. This implies if such countries would wish to move towards better final safety net provisions that then minimum income floors would have to be raised at least in step.

This would require quite substantial increases in minimum wages. In 2013, twenty Member States of the European Union have a national minimum wage, set by government, often in cooperation with or on the advice of the social partners, or by the social partners themselves in a national agreement. As is illustrated in Figure 5, presenting figures for 2010, only for single persons and only in a number of countries do net income packages at minimum wage level (taking into account taxes and individual social security contributions, but also social benefits) reach or exceed the EU's at-risk-of poverty threshold, as in all graphs set at 60 per cent of median equivalent household income in each country. For lone parents and sole breadwinners with a partner and children to support, net income packages at minimum wage are below this threshold almost everywhere, usually by a wide margin. This is the case despite shifts over the past decade towards tax relief and additional income support provisions for low-paid workers (Marx, Marchal and Nolan, 2013). 
[Figure 5. Gross minimum wages and net incomes at minimum wage as a percentage of the relative poverty threshold, 2010, selected EU Member States plus United States (New Jersey)]

When it comes to the question of whether and to what level minimum wages and hence minimum income benefits in general could be increased, opinions clearly diverge. Concerns about work disincentive effects of social safety nets are legitimate, as are concerns over potential negative employment effects of minimum wages, especially if these were to be set at levels high enough to keep households solely reliant on that wage out of poverty. The fact remains, however, that countries like Denmark or the Netherlands combine what are comparatively among the highest levels of minimum protection for workers and non-workers alike with labour market outcomes that on various dimensions are also among the best in the industrialised world. The Netherlands and Denmark enjoy among the highest employment rates in Europe and the lowest (long-term) unemployment rates.

Elaborate active labour market policies, specifically activation efforts directed at social assistance recipients, coupled with intensive monitoring and non-compliance sanctioning, appear to play a key role here. But it appears that the strength of overall labour demand is a key contextual factor for such associated policies and practices to effectively result in low levels of long-term dependence. Moreover, in terms of quality of employment, Denmark and the Netherlands are clearly among the best performers in the Europe with relatively few workers in low quality jobs (European Commission, 2008). Replicating the activation, empowerment and sanctioning aspects associated with comparatively generous systems may well be difficult enough in itself. Replicating a context where job growth is strong and where jobs are sufficiently rewarding and attractive may be even more difficult.

Relatively elevated social safety nets and other income protection systems can be compatible with well-functioning labour markets. In fact, such systems may actually conducive to well-functioning labour markets. Flexicurity proponents identify adequate social security benefits as an essential flexicurity pillar in that adequate benefits stimulate and accommodate labour market transitions and to reduce risk aversion among workers (Bekker and Wilthagen, 2008). 


\subsection{Child Poverty and Child Cash Transfers}

Children are generally at a higher risk of poverty than the population as a whole (Tarki, 2010; Atkinson and Marlier, 2010; Tarki, 2011). In addition, child poverty trends have for the most part not been favorable over the past decade (see also Chapter 9 in this Handbook). The latest 2010 EU SILC data shows that between 2005 and 2010 the at-risk-ofchild poverty rate increased in 17 out of 29 countries (EU27 plus Iceland and Norway). Child poverty rates rose in all the Nordic countries, Germany and France. In most countries where child poverty fell this was in part the result of a fall in the $60 \%$ of median income threshold due the recession (Czech Republic, Estonia, Ireland, Lithuania, Poland and Portugal). Poverty gaps (the gap between net income and the poverty threshold) for children have also risen between 2005 and 2010 in 15 out of the 29 countries. This deteriorating situation is of course the result of rising unemployment. However in 2010 the majority of countries in the European Union have more than $20 \%$ of poor children living in households with all working age members in employment (work intensity of 1) and all but Belgium, Bulgaria, Czech Republic, Finland, Hungary, Ireland and the UK have more than half of their poor children living in households with a work intensity of 0.5 or over (Van Mechelen and Bradshaw, 2013).

There are a number of reasons why children are living in poverty when their parents are employed. One explanation is that their earnings are too low either because they are working part time and/or full-time but their wage is low. The second explanation is that families may be taxed into poverty - the direct taxes taken in income tax and social insurance contributions reduces their gross incomes so much that they fall below the poverty threshold. The third explanation is that the cash benefits paid by the state to help parents with the costs of raising children are inadequate. Finally the reason why a child with a working parent may be poor is that after having paid for housing and other charges the resources available for consumption are too little.

Countries use different mixes of tax benefits and cash benefits for delivering help to families with children. One can distinguish between income related and universal - i.e. nonincome related - cash benefits. Income related benefits aim to target direct cash transfers to low income families. Governments may decide to target benefits to other specific groups, for example lone parents or disabled children. Tax instruments are also used to redistribute income from childless families to families with dependent children - either in the form of tax allowances or tax credits specifically aimed at families with children. Tax allowances are 
deducted from taxable income whereas tax credits are subtracted from the amount of tax due. Tax credits may be wasteable or non-wasteable. Non-wasteable or refundable tax credits are tax benefits that can be paid as cash transfer to the taxpayer whenever the benefit exceeds tax liability. Wasteable tax credits can only be used if tax liability is positive. Both cash and tax benefits tend to vary by the age and the number of children (Bradshaw and Finch, 2002; Van Lancker et al 2012).

Child benefit packages as a whole play an important role in preventing against financial poverty. Nevertheless, in many countries child benefit packages fail to protect low wage earners against poverty. In all countries the incomes of single earner couples on minimum wages is below the poverty line. The child benefit package for a lone parent is more generous in most countries. However, how and whether child care costs are subsidised makes a big difference to the package especially for lone parents. The costs of childcare can undermine the value of the package in some countries. Whereas during the 1990s child benefit package have been able to escape welfare erosion, over the past decade the value of the package relative to median equivalised income has fallen in more countries than it has increased (Van Mechelen and Bradshaw, 2013). This trend of decreasing child benefits has affected both low paid families and the better off.

Various studies have looked in detail at the structure of the child benefit package (e.g. Bradshaw and Finch, 2002; Bradshaw, 2006; 2010, Corak et al. (2005), Matsaganis et al. (2005), Van Lancker et al. (2012) have documented the adequacy of child support arrangements in terms of poverty alleviation using empirical income surveys. Corak, Lietz and Sutherland (2005) find that universal child related benefits that also have some degree of targeting at the poorest protect best against poverty. Their conclusion that targeting within universalism yields the best outcomes is echoed by Van Mechelen and Marchal (2013). They find that cross-country variation in the level of child benefit packages for single earner families on low pay largely overlaps with the degree of low income targeting. Model family type simulations suggest that comparatively generous packages for low paid workers are to be found in countries where financial help for families with children is well-targeted at lowincome households by means of income-related cash benefits, refundable income-related tax credits or social assistance top-ups. However, model family type simulation effectively assume full-take up of benefits and full granting of rights. In reality selective benefit systems may be quite ineffective with regard to poverty alleviation due to take-up problems and labour market disincentives (Atkinson, 1998; Deacon and Bradshaw, 1983; Gassman and Notten, 2008). Van Mechelen and Bradshaw (2013) also show that child benefit packages are 
often also above average in countries with universal cash benefits, but combined with income-related cash benefits, housing allowances or supplementary benefits from social assistance (Ireland, France, Austria, Finland). This finding may in effect confirm and reinforce the assertion in empirical literature that that targeting may be not so bad, if embedded in a universal social insurance context (Skocpol, 1991; Whiteford, 2008; Kenworthy, 2011; Van Lancker et al., 2012).

\subsection{The Working Poor and Combating In-work Poverty}

The issue of in-work poverty has received increased attention recently (Andre $\beta$ and Lohmann, 2008; Lohmann, 2009; OECD, 2008; European Foundation, 2010; Fraser et al., 2011; Crettaz, 2011; Maitre et al. 2012; Marx and Nolan, 2013). It is usually linked to the growth of low-paid insecure employment in the service sector. The contrast is often drawn with the golden years of welfare capitalism when manufacturing industry provided stable, well-paid employment even for those with little or no formal education. As Esping-Andersen et al. (2002) put it: "We no longer live in a world in which low-skilled workers can support the entire family. The basic requisite for a good life is increasingly strong cognitive skills and professional qualifications... Employment remains as always the sine qua non for good life chances, but the requirements for access to quality jobs are rising and are likely to continue to do so.' By the same token, Bonoli (2007: 496) states: 'Postindustrial labour markets are characterized by higher wage inequality with the result that for those at the bottom end of the wage distribution, access to employment is not a guarantee of a poverty-free existence.'

At the same time that good jobs for the less skilled are becoming scarcer an increased policy emphasis on activation has become evident in many European countries, certainly at the level of rhetoric, and gauging by some indicators also in terms of actual policy (Barbier and Ludwig-Mayerhofer, 2004; Kenworthy, 2008; Eichhorst and Konle-Seidl, 2008; OECD, 2007). Within the broad set of activation strategies deployed, an important number specifically target the long-term unemployed, including social assistance recipients. And within this set an important number of measures are aimed at stimulating these people, who generally have low levels of educational attainment, into relatively low-paid/minimum wage level jobs.

So has in-work poverty become more prevalent? The literature on the working poor employs a variety of definitions, based on different approaches of what is meant by 'poor' and by 'working' (for an overview see: Nolan and Marx, 2000, Crettaz and Bonoli, 2010). 
The working poor are conventionally defined and measured as those individuals who have been mainly working during the reference year (either in employment or self-employment) and whose household equivalised disposable income is below $60 \%$ of the median in the country in question. It is widely recognised that analysis of in-work poverty needs to distinguish between employees and the self-employed, both because their differing nature and because survey information on self-employment income is normally less reliable than wages and salaries, and also between full-time and part-time workers which is another important distinction. In fact, with the growth of part-time work, zero hours contracts, internships etc. 'being employed' has become a very fuzzy heterogeneous concept indeed. Moreover, combining two levels of analysis - the individual's labour market status and the household's income (adjusted for household size) - inherently complicates interpretation, since the labour market status of other persons in the household, rather than that of the individual being considered, may be crucial, as may the number of dependent children if any. Using a year as the reference period for labour market status and income position also complicates interpretation: those working for part but not all of the year may be in poverty on an annual basis for that reason even if they were not poor while working - and how much of the year does one have to work to be counted as "working”? For these and other reasons, this definition/measure makes it difficult to identify the different factors potentially underlying the phenomenon and thus the locus(es) of policy failure, which could include: low (household) work intensity; inadequate out-of-work benefits; inadequate earnings; inadequate earnings supplements, the number of dependent people (children) relative to income...

Data from the EU-SILC database clearly shows that in-work poverty is a Europe-wide phenomenon. The prevalence of in-work poverty varies across EU countries the extent of inwork poverty ranges from a low of 4-5 percent in Austria, Belgium, the Czech Republic, Finland, The Netherlands and Slovenia up to 13-14 per cent in Greece and Spain and 17 per cent in Romania. On the basis of Eurostat figures, which combine data from ECHP and SILC, we can seek no general tendency for in-work poverty to have risen since the start of the century. Taking the time span from 2000 to 2010, in-work poverty is seen to have increased over the decade in countries such as Denmark, Germany, Spain, Luxembourg, Romania and Sweden, but fell in as many countries. Abstracting altogether from the crisis period, comparison of 2000 with 2006 also fails to show a marked rise in in-work poverty in many countries. The common presumption of a rising trend is therefore not supported, by this data and indicator. However, the fact that the sources of data for 2000, unlike the later years, are not EU-SILC means that the trends shown has to be treated with some caution. 
It is useful to relate these figures and trends to analysis by the OECD, providing a point of comparison and covers the decade from the mid-1990s to the mid-2000s (see OECD, 2009). Drawing on a variety of sources but seeking to apply a uniform methodology, the OECD found in-work poverty to have increased substantially in EU countries such as Germany, The Netherlands and Luxembourg over this decade, but with some other countries such as Italy seeing substantial declines. The OECD figures also draw on different data sources and employ a different definition - in-work poverty being measured as households below 50 per (rather than 60) cent of median poverty threshold (with a different equivalence scale), and with "working” being captured at household rather than individual level by the presence of at least one person in work in the household. The study by Airio (2008) of the period 1970-2000 covering six OECD countries (and mostly based on data from the Luxembourg Income Study) concludes that it is difficult to find any common trend on inwork poverty. These differences illustrate the care which must be exercised in drawing strong conclusions about levels and trends in in-work poverty across countries, since definitions, data and period covered can all affect the outcome.

Which policy action, or set of policy actions, is most appropriate cannot be seen as entirely independent from normative notions that underlie the various ways the causes of working-age poverty in relation to work can be construed. Take for example a dual adult household with only one working adult and three dependent children. The male breadwinner has a low-paid job, yet is paid well above the minimum wage. Child benefits are limited. Whether their at risk of financial poverty status is construed as a problem of insufficient breadwinner earnings, or as a problem of partner non-participation, or as a problem of insufficient child support makes a fundamental difference as to what type of policy action is to be examined and possibly favoured. In the case of traditional breadwinner type households with insufficient earnings, the preponderance of opinion in Europe appears to be that this is to be seen as a matter of partner non-participation or under-participation. But other cases may be less clear-cut. Even if in-work poverty is construed as largely a problem of low household work intensity, the question arises what can be deemed to be sufficient level of work intensity. It is not self-evident that that this is to equal all working-age, work capable adults in the household to be in full-time work the whole year round. Societal norms may differ across countries. In the Netherlands, for example, a 4/5th job per adult appears to be closer to the norm of full-work intensity. Also, household composition may be deemed to matter. It is not self-evident that a lone parent with young children is expected to work full-year, full-time 
before additional income support is to be considered legitimate if his or her earnings fall short of the poverty threshold.

Poverty is to a large extent yet far from exclusively associated with low work intensity at the household level (see De Graaf-Zijl and Nolan, 2011; Vandenbroucke and Corluy, 2013). This brings into view a wide variety of potential policies that can help households to increase if not maximize their work intensity. These include policies aimed at boosting the demand for workers, and particularly the demand for people with low levels of education or weak work experience. Employer subsidies or reductions in employers' social security contributions are an example here. At the supply side, policy can stimulate (e.g. through fiscal reform) or support (e.g. through child care) people to take up work or to increase working hours. What mix of policies will work best in a given context will depend on the composition of the low work intensity population and on the underlying causes of low work intensity.

Yet, and this is crucial, it must be recognised that even if such policies succeeded in getting every single non-employed person into work, or every household to a level of full work intensity for that matter, (and all empirical evidence to date suggests this to be highly unlikely), this would not guarantee the elimination of poverty. What policy can do to help households in these circumstances is again likely to depend on such factors as the institutional and policy context in place, labour market conditions and the profile of the population in need of support.

In some EU countries, and certainly outside of the EU, minimum wages remain nonexistent or low relative to average wages, but in a range of others they do suffice to keep single persons reliant on them out of poverty. Thus it would appear sensible for countries with non-existent or very low minimum wages to contemplate introducing or increasing these. However, the route of introducing or boosting minimum wages to the upper ranges currently prevailing in Europe (relative to average earnings) would, even in the absence of negative employment effects, not be sufficient to eradicate in-work poverty. Even in countries where minimum wages are comparatively high they do not suffice to keep sole breadwinner household out of poverty, especially when there are dependent others or children. Minimum wages have probably become inherently constrained in providing minimum income protection to sole breadwinner households, especially in countries where relative poverty thresholds have become essentially determined by dual earner living standards. 
For low-earnings households, only direct household income supplements may offer a reasonable prospect to a poverty free existence, especially when there are dependent children. Such 'in-work benefits' are now often associated with Anglo-Saxon-type "tax credits” such as the EITC in the United States and the WTC in the United Kingdom. It is increasingly argued though that more effective redistribution will not come from augmenting/expanding the traditional channels of income support, for example more generous social insurance or social assistance levels, or from higher minimum wages. These are seen as not only as failing to address today's social risks and needs, but as exacerbating underlying problems such as exclusion from the labour market and entrapment in passive benefit dependency. Worse, have are considered as standing in the way of innovative mechanisms of social protection that are pro-active and self-sufficiency enhancing, such as active labour market policies and services such as child care, and improved education and training.

The option to consider, then, are other forms of (targeted) income supplements for households that provide some level of income protection but that are also conducive to labour market participation. As Kenworthy (2011) puts it, 'Given the importance of employment and working hours for the market incomes of low-end households, policy makers must guard against programs that provide attractive benefits without encouraging or requiring employment. An ideal transfer would be one that both boosts the incomes of low-earning households and promotes employment by able working-aged adults. As it happens such a program exists. Referred to variously as "in-work benefit” or "employment-conditional earnings subsidy”, it is best exemplified by the Working Tax Credit (WTC) in the United Kingdom and the Earned Income Credit (EITC) in the United States”. (p. 44)

Under these schemes households with low earnings do not pay taxes but instead they receive additional money through the tax system. In the United States, the 1993 expansion of the Earned Income Tax Credit (EITC) turned it into the country's pre-eminent anti-poverty program for families of working age. The United Kingdom has also implemented and extended several schemes (and in fact did so earlier than the US), culminating in the Universal Credit. Clearly, Anglo-Saxon style negative income taxes have been garnering increased interest of late. As Immervoll and Pearson (2009) note, "Even in the mid-1990s, twenty years after such schemes were first introduced in the United Kingdom and the United States, such schemes were seen as interesting but unusual [...] it seems reasonable to conclude that IWB schemes are now mainstream policies in many countries.”

That is perhaps somewhat of an overstatement. Several European countries have contemplated introducing Anglo-Saxon-style tax credits, or have done so in some form. 
Examples here include the 'Prime Pour l'Emploi' (PPE) and the Revenue de Solidarité Active (rSa) in France, the 'Combination Credit' in the Netherlands, and a "Low Wage Tax Credit” in Belgium. Yet the reality is that most of these schemes exhibit only a faint resemblance to the EITC or the WTC. Sweden has a scheme that goes by the same name in English as its American counterpart EITC. It was introduced in 2007, and was reinforced in 2008, 2009 and 2010. The stated motive of the reform was to boost employment; in particular to provide incentives for individuals to go from unemployment to, at least, part-time work. The scheme is different from the American scheme in that it is a non-refundable tax credit. Also, because the tax unit in Sweden is the individual and not the household it works in effect as tax relief on low individual earnings. In that respect it is similar to personal social security contributions relief measures elsewhere.

While tax-channelled in-work benefits targeted at households with low earnings remain of limited significance in most European countries, it is of course the case that many countries have child benefit systems that provide an additional income to workers and their families (Van Mechelen and Bradshaw, 2013). Child benefits have generally lost ground. For a couple with two children, the size of the child benefits package, expressed as a percentage of the gross minimum wage, declined in the majority of countries awarding these benefits. For lone parents with two children the trend was somewhat more favorable in a number of countries. The decline of child cash benefits, both in value as in their importance in net disposable income, is discussed more extensively in Van Mechelen and Bradshaw (2013). Interest in EITC type schemes remains strong however, in the public debate and in the academic literature (Kenworthy, 2011; Figari, 2011, Allègre and Jaerhling, 2011; Crettaz, 2011; Marx et al., 2012; Aaberge and Flood, 2013). That interest seems entirely legitimate. The empirical evidence shows the American EITC, in combination with other policy reforms and several increases in the minimum wage, to have produced some significant results, including marked increases in labour market participation and declines in poverty among some segments of the population, especially single-parent households (Hotz and Scholz, 2003; Eissa and Hoynes, 2004). It needs to be noted, however, that these initial results happened in favourable economic circumstances, including strong labour demand and low unemployment. The relatively strong increases in labour supply of lone mothers in the American setting also resulted from welfare reform, notably the transformation of the social assistance scheme into a temporary support system with time limits on the duration of benefits. This clearly provided a strong push incentive, with the EITC acting as pull incentive. Not all who were forced out of passive dependence found their way to work. 
(Grogger, 2003; 2004) In addition, as the survey by Holt (2011) brings out, there is considerable evidence of incomplete take-up (around 75 per cent according to some estimates), although exact estimates are hampered by the fact that there is no systematic tracking.

There are potential downsides to subsidizing low paid work. While EITC is intended to encourage work, EITC-induced increases in labour supply may drive wages down, shifting the intended transfer toward employers. Rothstein (2010) simulates the economic incidence of the EITC under a range of supply and demand elasticities and finds that in all scenarios a substantial portion of the intended transfer to low income single mothers is captured by employers through reduced wages. The transfer to employers is borne in part by low skill workers who are not themselves eligible for the EITC. There is some empirical evidence that corroborates the potential wage erosion effect of EITC (Leigh, 2010; Chetty et al., 2013)

Yet whether EITC type schemes can work elsewhere, as Kenworthy (2011) and others suggest, is not self-evident. The socio-demographic make-up of the US differs from that in most European countries; there are more single adult (and parent) households but also more multi-earner households. The dispersion in earnings is also much more compressed in most European countries, where, in addition, benefits are generally higher relative to wages (including minimum wages) and less subject to means-testing if they derive from social insurance. This also implies that benefit entitlements of household members are less interdependent, possibly weakening the potential impact on labour supply. Many countries have individual taxation, and the trend is away from joint taxation of couples.

In order to be effective as an anti-poverty device and at the same time affordable within reasonable limits, such measures need to be strongly targeted. However, strong targeting at households with low earnings is bound to create mobility traps, which can only be avoided if taper-off rates are sufficiently flat. That comes at a very considerable cost if the lower end of the household earnings distribution is densely populated, as is the case in many European countries. This cost can only be avoided by making the amount of the tax credit itself smaller, but in that case the anti-poverty effect is reduced. Simulations by Bargain and Orsini (2007) for Germany, France and Finland, by Figari (2011) for four southern European countries (Italy, Spain, Portugal and Greece) and by Marx et al. (2012) for Belgium shed doubt over the applicability of EITC type systems in other settings. In an earlier study, Bargain and Orsini (2007) investigated the effects on poverty of the hypothetical introduction of the British scheme (as it was in place in 1998) in Germany, France and Finland, using EUROMOD for 2001. They found that the anti-poverty effects of a UK type tax credit 
(similar in design and relative overall spending) would be very small in these countries, especially relative to the budgetary cost. For Belgium, the hypothetical introduction of the UK's WTC is shown to yield a limited reduction in poverty at the cost of possible weakened work incentives for second earners (Marx et al., 2012). Figari (2011) notes that the presence of extended families in southern Europe does not allow for such policies to be well targeted at the very poorest. Bargain and Orsini (2006) have concluded that "interest in such schemes is destined to fade away". Whether that is true remains uncertain and indeed doubtful, but EITC type negative tax credits are not obviously suitable for wholesale emulation throughout continental Europe. In Germany, for example, the labour market has undergone some profound changes over the past decade. Low paid employment has become far more prevalent and in-work poverty seems to have increased. It is not unlikely that a simulation like the one performed by Bargain and Orsini on 2001 data would yield different results today. A recent study by Giannelli et al. (2013) analyse the quality of the new jobs created in Germany between 1998 and 2010 and find that the reforms of 2000's (Hartz reforms) reinforced an existing trend of increasing wage inequality and lower wages among the least advantaged individuals. Although, as found by Card et al. (2013), a great deal of the increase of wage inequality in Germany for the period 1985-2009 is due to the increasing heterogeneity in job premiums and the raise of assortativeness in the matching between workers and establishments.

Clearly, simulations demonstrate that in-work benefit schemes that work well in certain settings do not necessarily perform equally well in a different context. Family composition, individual earnings distributions and family income structures drive outcomes in a very substantial way. It remains to be explored whether alternative designs are conceivable that have better outcomes in continental European settings and that are realistically affordable.

\subsection{Pensions}

The terminology of 'pillars' is widely employed (Holzmann and Hinz, 2005) to capture the different elements of pension systems, as they operate within for example Bismarckian or Beveridgean welfare states. Bovenberg and Van Ewijk (2011) offer a typology of four models of pension systems based on the dimensions of governance (private vs. public) and individual choice (mandatory vs. voluntary), which are related to the classification of welfare states by Esping-Anderson (1990). As pension systems in rich economies have, 
simultaneously or not, characteristics of social insurance and poverty prevention, and different forms to finance benefits, a more flexible taxonomy of pension systems is used by the OECD (see Figure 6).

[Figure 6: Taxonomy of different types of retirement-income provision]

There are three main visible tiers forming the retirement-income system. The first one is intended to prevent old-age poverty and is publicly financed. Within this tier there are basic benefits paid at a flat rate, resources-tested (means and assets) benefits, and minimum pensions. The second tier is composed by mandatory schemes that can be public or private. The public schemes offer defined benefits (DB) where the pension entitled is a function of individual contributed years and income. A system of points earned with each year income and accrued up to retirement age is also possible (e.g. occupational plans in France). A third plan under the public provision of the second tier is the Notional Defined Contributions (NDC), which is used in Italy, Norway, Poland and Sweden. Under this plan, the individual contributions are recorded by the pension institution and offered a return rate. Once the retirement age is reached such contributions are converted into pensions through an actuarial formula. The second tier also includes compulsory private (occupational) managed pensions which can be DB or defined contribution (DC) types. Finally, the third tier is composed by voluntary private plans.

The composition of each plan within and between countries varies to great extent. From 34 OECD countries, 14 have mandatory private schemes, 12 have public resourcestested benefits, 13 have basic flat rate benefits and 18 have minimum pensions. Furthermore, DB pensions are present in 20 countries whilst DC pensions exist in 11 economies. For more details about the composition of pension plans by county, see section II.1 of OECD (2011).

\section{[Figure 7. Net pension replacement rates by pension schemes in OECD countries]}

The adequacy of pension benefits is broadly measured by the replacement rate, i.e. the ratio between pensions and average wages. Figure 7 reports the net pension replacement ratios in OECD countries with data from late 2000's. On average, the replacement rate is $50 \%$ in mandatory public plans while it is $43 \%$ in mandatory private plans and $28 \%$ in voluntary plans. Overall, the mandatory systems show a replacement rate of $68 \%$ which rises to $77 \%$ 
when voluntary plans are added. Furthermore, one can observe that adequacy differ significantly among countries and pension schemes. For example, in Japan, Korea and Mexico the overall net replacement rate is lower than 50\% while in 13 over 34 countries this figure is above $80 \%$. All the replacement ratio figures are lower when gross income and pensions are considered because income taxation burden for retirees is milder than for the working population. The mandatory systems have a gross replacement ratio of $57 \%$ and this reaches $64 \%$ when voluntary plans are included.

Typically, individuals at the beginning and the end of the life-cycle face higher poverty rates. This $U$ relationship by age groups has been maintained during the last decades, but the poverty rates have shifted impressively in favour of the elderly and in detriment of the children and young. Figure 8 from the OECD’s Unequal Growing?, shows clearly the sharp reduction of poverty risk for old-age individuals between 1970's and 2000's in OECD countries. Moreover, women report more poverty rates than for men. The poverty gap by gender significantly increases for older ages. As explained in OECD (2008), Smeeding and Sandstrom (2005) and Vignoli and De Santis (2010), the risk of living in poverty is higher for elderly women because they have gained less pension rights during their working life and they are more likely to live alone after the death of their spouses. In this regard, studies from Burtless (2009) and Vignoli and De Santis (2010) alert on the trends of new living arrangements (shrinking of the household size of the elderly) that jeopardize the living conditions of the elderly and increase the risk of falling into poverty. As a feedback mechanism, the larger participation of the elderly in pensions and transfers will allow them to live alone without the need of other relatives, increasing in this way the risk of poverty. McGarry and Davenport (1998) are also aware about the effects of survivorship benefits for pensions on the poverty rates of American widows given the scarcity of pension wealth of women.

[Figure 8. Risk of relative poverty by age of individuals in OECD-7 countries (Poverty rate of the entire population in each year $=100)]$

The role of pensions in reducing poverty is particularly important due to the large share of old-age income coming from social security. On average, public transfers (earnings-related pensions, resource-tested benefits, etc.) to people over 65 during the mid-2000's represent $60 \%$ of their incomes, with some countries where this figure reaches $80 \%$ or more (France, Hungary, Slovak Republic and Belgium). The rest of the sources are divided in work income 
(21\%) and capital income (19\%). The shares of incomes from work are large in Japan, Turkey Mexico and Korea where those represent about 50\%. The average share of capital income for the elderly in Netherlands, United Kingdom, Switzerland, Canada, Australia, Denmark and United States, is about 41\%. Note that occupational plans are included in capital income sources, so that this component includes pension incomes. All these figures by country can be consulted in OECD (2011). It is also observed that the reduction of market income poverty attained with transfers and taxes is greater for old-age people than working age people (OECD, 2008).

A number of recent studies have sought to measure the contribution of pensions in reducing old-age poverty across countries. Smeeding and Williamson (2001) use LIS data to estimate the effect of public pensions on poverty rates of the elderly in eight developed economies for mid-1990s: Australia, Canada, France, Germany, Netherlands, Sweden, United Kingdom and United States. The poverty rate for old-age people would be $84 \%$ in average if only market income is considered. This is reduced to $71.8 \%$ when occupational pensions are added and then this falls to $21.2 \%$ when universal and social incomes are included. With social safety net transfers, the average poverty rate drops up to $13.2 \%$. Different from the English-speaking countries, the greatest redistributive effects are found in France, Germany, Netherlands and Sweden. Similar trends are found when Smeeding and Sandstrom (2005) analyse data for early 2000s. In both works, it is found that pensions are more effective to reduce poverty of old-age males than that of females. With early 2000's data, pensions, income social transfers and safety net transfers reduce poverty of elderly women up to $24.3 \%$ while that figure is reduced up to $13.3 \%$ for both sexes. As women participate to less extent in the pension system, the safety net transfers are more important for them to reduce their risk of poverty, and the contrary holds for occupational pensions in the case of men. In a similar exercise by Lefebvre (2007), it is found that poverty alleviation due to pensions is less effective for the very old (75+) than for the old (65-74). This feature combined with gender depicts a very negative picture for the very old women, who in turn, represent the majority of members in the oldest old cohort. Moreover, micro-simulation models like the one implemented in Dang et al (2006) arrive to similar conclusions. Chapter 26 of this Handbook show other relevant micro-simulation models.

There is a concern about the sustainability of public pension expenditures due to the accelerated aging process in developed economies; and in particular, there is a legitimate worry about the effects of the reforms aiming to attenuate it on old-age poverty and inequality (Burtless, 2006; Börsch-Supan, 2012; Arza and Kohli, 2008). Although, as 
indicated in the reports by Zaidi et al. (2006a, 2006b) the pension reforms promoted by the World Bank were mainly driven by financial sustainability issues and little concern was put on the effects on the living standards of the retirees. These reports are an important effort to estimate the long term effects of a variety of pension reforms in EU countries - undertaken between 1990's and 2000's- on the poverty and living standards of the elderly. In Zaidi et al. (2006b), the authors find a strong negative relationship between the generosity of public pensions and the at-risk-of-poverty rates among the 65+, and foresee a decline of the pension generosity (for years 2025 and 2050) on the basis of the analysis of each pension reform. These two combined findings will result in an increase of the poverty rate for the vast majority of countries analysed (Estonia, Malta, Austria, Italy, Belgium, Denmark, Spain, France, Latvia, Lithuania, Portugal, Slovenia, Finland and Sweden). Only Ireland and Cyprus appear to have a reduction of the 65+'s poverty rates. However, as warned by the authors, these results have to be taken with caution as no behavioural responses are considered.

In a more static framework, Van Vliet et al. (2102) estimate the effects of pension reform on poverty and inequality in European countries. They acknowledge that recent shifts from public to private provision in pensions are still limited in Europe but it is important for some countries. They estimate the effects of those changes on old-age inequality and poverty with OLS panel data regressions, but they do not find substantial effects on those variables. Nonetheless, they cast the limitation of their analysis by indicating that the reforms may be affecting only to new and future retirees.

Looking at the effects of public transfers and taxes in a more general way, some authors appeal for a rebalance of the spending from pension programs towards programmes aimed to prime age people and their children at the bottom of the income scale, which could reduce poverty rates to a greater extent (OECD, 2008). As pointed by Dang et al. (2006), social protection systems are very old-age oriented in EU with the elderly receiving much more cash transfers than the working population. They show that even high old-age spending countries can leave significant pockets of elderly in poverty while others with lower expenditures in old-age can be more successful at limiting the risk of poverty. Furthermore, their simulations indicate that there is scope to reorient the expenditures from old-age to working population and rebalance the tax liabilities in favour of the working population. These changes will not jeopardize the living standards of the elderly if the reforms include proper safety net measures.

The role of public pensions in reducing inequality can be very large because these pensions represent a large fraction on income in old-age. During the mid-2000s, public cash benefits 
accounted for $70 \%$ of income of retirement age individuals in 24 OECD countries, and in many of them the figure was above $80 \%$ (OECD, 2008). In countries where public pensions are important, the effect of re-ranking when one use the distribution of market or disposable income as the counterfactual can be large. Mahler and Jesuit (2006) find a sizeable effect of pensions (public and private) in reducing the Gini coefficient on 13 rich countries during the period 1980-2000. On average, the Gini is reduced from 0.43 to 0.27 when all taxes and transfers are considered, with a reduction of 0.039 points from taxes and 0.121 from transfers of which 0.068 comes from pensions, 0.013 from unemployment transfers and 0.040 from other transfers. In Belgium, Sweden and France, the reduction in the Gini is about 0.10 points due to pensions, while in US, Canada and Australia is only about 0.04 points. Lefebvre (2007) computes the marginal contribution of earnings, property income, private pensions and public transfers on total inequality in 19 EU countries. It is found that public pensions decrease inequality in all countries and that private pensions increase inequality in all countries but in Ireland and France. Similarly, Caminada et al. (2012) disentangle the changes of contributions of different income components in reducing inequality between mid-1980's and mid 2000's in 12 LIS countries. Around 1985 the primary income gini falls 0.139 points after transfers and taxes, while that around 2005 this drop is about 0.163 points. The authors estimate that this increase in redistribution is mainly due to the state old-age and survivor benefits, which account for $60 \%$ of the total change. Different designs of pension systems have diverse effects on inequality. For example, Benedict and Shaw (1995) with data from early 80's, find that private pensions in US increase inequality among unionized workers by $21 \%$ with respect to observed wage inequality. On the reforms undertaken in Europe since mid-1990s, Van Vliet et al. (2012) do not find evidence of important effects of those reforms on income inequality.

In general, the assessment of inequality is made in one single year, but studies such as Butler (2006) emphasise that this approach can overestimate the redistributive impact of pensions. This is related to the question of what is the proper counterfactual distribution to use when one analyses the impact of pensions. If pensions are simply absent, it is expected that individuals will look for other forms of savings to afford their old-age. Different living arrangements can also be different if pensions would be non-existent or less generous, which will cause other redistributive effects (Burtless 2006, 2009). In this regard, some authors favour the estimation of the distribution of lifetime income (e.g. Liebman, 2002 and Deaton et al., 2002) although the data requirements are more demanding. This approach shares features with a growing literature studying lifetime income inequality (see for instance 
Aaberge and Magne Mogstad (2012)) which highlights a life-cycle bias that over-estimates income inequality when only one or few years are analysed.

\section{Section 3: Beyond Social Protection}

\subsection{Non-Cash Social Spending and Poverty}

While cash transfers form a substantial proportion of overall social expenditure and have a pronounced impact on household incomes and poverty, other forms of social expenditure - such as on health, housing, and perhaps education (which is sometimes included as 'social' spending and sometimes not) - may also have substantial direct and indirect effects. Table 4 shows spending on cash transfers and on other forms of social expenditure - which one can think of as benefits in kind from a household perspective - based on the OECD's social expenditure database, before the onset of the economic crisis in 2007-8 which has boosted expenditure on cash transfers in many countries. This shows that in about half the countries shown, cash transfers significantly outweighed such benefits in kind notably in the 'Continental/corporatist' countries like France, Germany, Belgium and Luxembourg, in the Southern countries Italy, Spain and Greece, and in Poland. However, in many of the other OECD countries overall social spending was fairly evenly balanced between cash transfers and other spending. This is using a definition of social expenditure that does not include education, so if one adds on education spending the relative importance of non-cash spending is even more obvious, as brought out in Marical, Mira d'Ercole, Vaalavuo and Verbist (2008). They conclude that public spending on health, education and 'other services' in the OECD social expenditure database represent an amount comparable to public cash transfers, exceeding those transfers in 11 OECD countries.

[Table 4. Social Expenditure Distinguishing Cash and Non-Cash Benefits as Percentage of GDP in OECD Countries, Mid-2000s]

The impact of such non-cash spending on poverty is difficult to assess, for various reasons (see for example Currie and Gahvari, 2008; Garfinkel, Tainwater and Smeeding, 2006). One approach, employed in comparative studies such as Smeeding et al. (1993), Marical et al. (2008), Callan, Smeeding and Tsakloglou (2008), and Paulus, Sutherland and Tsakloglou (2010), and in national studies such as Aaberge and Langorgen (2006), Callan and Keane (2009), Nolan and Russell (2001), Harding, Warren and Lloyd (2006) and Wolff 
and Zacharias (2007) is to use micro-data to assess who is benefitting from such expenditure and to what extent, and to compare overall inequality and (sometimes) poverty levels when this non-cash income is included - with some studies also allocating indirect taxes to households and deducting them to arrive at a 'final' income concept. Major decisions have to be made about how to value the benefits to users of services, as has been debated in the literature for three decades, and the empirical studies have shown that these can have a marked impact on the measured outcomes, notably in the case of health spending where particularly challenging conceptual issues have to be addressed.

One complication is that services which in principle are provided free or in subsidised fashion to everyone may actually be readily available only in certain areas or to certain groups, or even if available may be taken up to a varying degree by those with higher versus lower levels of income or education. Information on actual use patterns may not always be available, and attributing a common value across for example a particular age group may then be misleading. Empirical studies thus make use, where possible, of information - generally from household surveys - of actual usage patterns for the range of services involved, but this may not cover all the areas of expenditure one wants to include.

Difficulties then arise, though, first of all because one does not know whether households would have bought the same amount of the goods or services in question if those were not provided free or at a subsidised rate. Recipients may place a value on non-cash benefits that is less than what they would have to pay for the good or service in the market, because the recipient has no choice in its allocation. However, a US study of food stamps suggested that where the item is a basic necessity and the in-kind transfer is smaller than the amount the household would normally spend on that good, the value to the recipient may be very close to the market price (Moffitt, 1989). Unlike food, what is meant by market price for many of the services provided by the state may itself be unclear since they are not available in the market - the most obvious examples being defense or law enforcement. If one takes the supply price (i.e. the cost to government) as the point of reference, the optimal level of provision will equate the marginal benefit with this price times the marginal cost of public funds. In any case, the widely-used approach in empirical studies is simply to assume that the value of a particular (unit of a) service is equal to the average cost of producing it. Use of such an average may mask variations in quality of the service provided to different socioeconomic groups - for example in the quality of the healthcare provided to the rich versus the poor - and that is another important aspect that is very difficult to capture empirically. 
The second general issue arises where the non-cash benefit covers something like health care, which is required to meet a specific contingency affecting only some households in a given year. In those circumstances, if we simply add the cost of the free or subsidised services supplied to the households consuming them, sick people will be richer than the healthy at any cash income level. One can in those circumstances attempt to also take the additional 'needs' of such persons into account by elaboration of the equivalence scales employed - drawing on for example recent studies focused on the costs associated with disability such as Jones and O’Donnell (1995), Zaidi and Burchardt (2005) - but this remains underdeveloped. A more widely-employed approach is that instead of basing values on the household's own consumption, one attributes to all those eligible for State provision an extra income equal to the insurance premium they would have to pay to obtain the same level of cover in the market. Even assuming the cost of this cover can be established satisfactorily, a serious problem remains however. Even the insurance value could be worth enough by itself to bring a household above the poverty threshold, when they might still have insufficient cash income to buy enough food, clothing or shelter, reinforcing the point that the in-kind transfer does not represent command over resources in the same way that cash income does. Furthermore, even with the insurance approach the fact that different households have different underlying needs should be taken into account in arriving at conclusions about the welfare implications of in-kind benefits (on which see Aaberge et al., 2010).

The final, and fundamental, issue to be noted relates to the time-period employed. In measuring poverty and income inequality annual income is most often the focus, but in thinking about the consumption of education or health care and the value of the in-kind benefit they represent it would be natural to take a life-cycle approach, since the benefits are often long-term rather than confined to the point of use. Such an approach is both very demanding in data terms and involves a wide range of assumptions for which it is difficult to find a robust empirical basis.

The results of recent empirical studies on this topic are of significant interest in the broader context of welfare state institutions and policies and their impact on poverty. Marical, Mira d'Ercole, Vaalavuo and Verbist (2006 - and also Chapter 9 in OECD, 2008) look at the impact of public spending on health, education and social housing on income inequality in OECD countries, concluding that they generally contribute to narrowing inequality, though not usually by as much as cash transfers and direct taxes combined; they do not look at corresponding results for poverty. Paulus, Sutherland and Tsakloglou (2010) on the other hand assess the impact of valuing non-cash or in-kind benefits from public housing subsidies, 
education and healthcare in five European countries, recalculating both inequality and relative poverty measures when this value is added to cash income. In such an exercise, importantly, the relative income poverty threshold - in this case $60 \%$ of median equivalised income - is itself recalculated, rising by between about one-fifth and one-third in value when in-kind benefits are included. The proportion of persons falling below that threshold is found to be much lower than the corresponding figure based on cash income in all five countries, that reduction being greatest in the UK where the poverty rate falls by half and least in Greece where it still falls by a third. There are also major impacts on the composition of those falling below the threshold, with the reduction in poverty ate greatest for children and older people (since the incidence of spending on education and health care is particularly concentrated on them). This pattern is familiar, having featured strongly in Smeeding et al.'s (1993) early comparative study covering seven countries based on data in LIS.

Sutherland et al. caution that 'it is doubtful whether these results should be interpreted as having any bearing on the assessment of poverty or inequality from a welfare perspective' (p. 259), being mainly of interest in showing the scale of noncash incomes relative to cash incomes, but without taking into account the needs of individuals for health care or education. The study goes on to attempt to take the variation in those needs into account via modifying the equivalence scales employed, and finds that the distributional effects of noncash transfers on several summary income inequality measures are then far more modest; corresponding results for poverty rates are not reported, but it seems likely that the same would be true in that case. It is also worth highlighting the argument by Bourguignon and Halsey (2007) that once the inter-temporal or intergenerational nature of the effects of many social expenditures are recognized, it is no longer possible to assume that they are equivalent to cash transfers, food subsidies, and other programs of direct redistribution. Education spending is an investment in future generations and may have redistributive effects for these generations, but may worsen distribution initially. Moral hazard makes it infeasible to borrow against the human capital of one's descendants, so an increase in public education expenditures financed by an increase in a neutral tax may actually be regressive for the generations with school-age children. Poor households in this generation pay the tax and receive no benefit, whereas rich households pay the tax but may recover it through intergenerational reallocation of consumption (that is, smaller bequests to their children). Intergenerational accounting may then be necessary to more fully capture the redistributive and poverty-related effects. 


\subsection{The Labour Market, Education, and Active Labour Market Policy}

Income derived from the labour market is central to the overall distribution of income, and to poverty and disadvantage at household level (see for example OECD, 2008). Even for those not currently earning (via employment or self-employment), previous labour market experience may determine current entitlement to social protection or to occupational pensions. A very wide variety of studies of poverty in individual countries, both descriptive and econometric, find that those in work are much less likely to be poor than the unemployed or working-age inactive. Cross-country differences in labour market performance and structure then seem a natural starting point in seeking to understand cross-country variation in poverty rates (Burniaux et al., 1998; Förster and D’Ercole, 2005). The poverty rate among the working-age population varies greatly across OECD countries and is indeed the main contributor to overall poverty headcounts (see for example OECD, 2009). However, at the country level working-age poverty - overall or for specific groups - is not in fact strongly linked to employment rates. Burniaux et al. (2006) report some relationship between female participation rates and poverty rates across OECD countries, but it is not particularly strong. Poverty rates are generally lower in low unemployment countries and vice versa, but there are notable exceptions, and a high employment rate is not a sufficient condition for low poverty among the working aged population. At the aggregate level, then, employment performances are not the main driver of cross-country differences in the overall poverty risk among the working-age population (OECD, 2009).

There is thus a contrast between micro-studies on poverty and the labour market in individual countries, which tend to focus on the labour market situation and experience of individuals and their households and the characteristics associated with good rather than bad labour market outcomes for them, and comparative studies at the aggregate level which focus on labour market institutions and performance. The relationship between individual characteristics and labour market outcomes is of course a core concern of labour market research, as is the structure of earnings in terms of overall dispersion and differentials. (For reviews see for example the Handbook of Labour Economics (Ashenfelter and Layard, 1987, Ashenfelter and Card, 1999, 2011), Blau and Kahn 2008, and Chapter 19 of the present volume by Checchi and Salverda). The extent to which individual disadvantage and relatively bad labour market outcomes manifest themselves in high poverty rates then depends on the household, labour market and institutional settings in which those disadvantages are experienced. Comparative studies of the relationship between poverty and the labour market 
at the aggregate level include collective bargaining structures, the role of unions, minimum wages etc. in the explanatory variables employed as key aspects of labour market institutions (see for example Burniaux et al., 2006). These may often be embedded in wider sets of variables covering for example welfare spending and structures, intended not only to serve as controls but also to capture broader concepts of the welfare state 'regime', as discussed in Section 1.4 above. This reflects a recognition that labour market institutions, while central, are inextricably bound up with the broader welfare state, and that the impact on poverty of for example a minimum wage will vary depending on that broader context - as brought out in our discussion of in-work poverty and social protection transfers in Section 2.4.

A core element of that broader welfare state, strongly linked to the labour market, is the education system and educational spending. Once again a contrast may be drawn between micro-studies on the relationship between educational attainment, earnings and poverty at individual or household level, and studies at the aggregate level which focus on the education system and spending and their impact on economic performance and poverty. The relationship between educational attainment and earnings/labour market outcomes for individuals has been a major preoccupation of labour market research since the earnings equation first derived by Mincer (1958) became a basic tool of analysis, but the broader role of education as a facilitator or engine of economic growth is also a major focus of research. The concept of 'human capital' has become embedded since the 'Chicago School' of economics (see especially Mincer, 1958; and Becker, 1964), with human capital seen as similar to physical means of production in that investment in enhancing capacities and skills, notably through education and training, also increases future productive capacity. Microeconomic investigation of this relationship via estimation of the returns accruing to the individual in terms of earnings is the topic of a vast array of empirical economic research, including investigation of the extent to which the positive earnings differentials for the more educated may be interpreted as a causal impact of education itself rather than selection (on which see for example Card, 1999, Machin, 2008). The impact of educational attainment on the likelihood of being in poverty is also a consistent finding from micro-econometric analysis of individual OECD countries or comparatively, and holds whether poverty is measured in terms of low annual income, persistent low income, or levels of deprivation (see for example Layte and Whelan (2002); Fouarge and Layte, 2005), though the relative and absolute 'penalty' paid for low educational attainment in terms of enhanced poverty risk varies substantially across countries. 
The implications of this individual-level link between educational attainment and poverty risk for aggregate performance and for policy is not as straightforward as it is often taken to be, and requires further research. Improving the education and skills of the workforce has assumed a central role in strategies to promote economic growth and tackle poverty and exclusion. This is illustrated for example by the European Union's 2013 Social Investment Package, focused on policies designed to strengthen people's skills and capacities, including education and childcare as well as active labour market policies (see European Commission, 2013), or in a US context by the Obama administration highlighting that "To prepare Americans for the jobs of the future and help restore middle-class security, we have to out-educate the world and that starts with a strong school system."7 This reflects in particular the concern that the low-skilled in advanced economies are being left behind by rapid technological change in a globalized world economy, as discussed in depth in for example Freeman (2008) and Chapter 21 by Kanbur in this volume. On the role of education in this context, OECD (2011) concludes for example that between the mid-1980s and mid2000s the sizeable disequalising effect on earnings of factors such as technological change, more flexible labour market regulation and less generous unemployment insurance was largely offset by growth in average educational attainment, up-skilling serving to reduce wage dispersion among workers and increase employment rates.

However, the corollary is not that continued expansion in education per se will be effective as an equalising or anti-poverty policy. As Checchi et al. (2014) emphasise, increasing average levels of educational attainment was associated with reducing dispersion in attainment in many OECD countries over the $20^{\text {th }}$. century, but with completion rates at second level approaching saturation in many rich countries, the main issue facing educational policies in most OECD countries now is whether they should pursue further expansion at tertiary level. Such expansion, depending on how it is brought about and underpinned, may not benefit those from poorer backgrounds, as we discuss in the context of intergenerational transmission of disadvantage in the next section. Research on how best to enhance skills in the middle and bottom parts of the distribution in secondary school, including performance in mathematics and languages, as well as issues of school system structures, tracking, and early childhood education, discussed in the next section are thus also central to the research agenda from a poverty perspective.

\footnotetext{
${ }^{7}$ http://www.whitehouse.gov/issues/education, downloaded 25 July 2013.
} 
Training and skill enhancement, as well as matching, are important components of the active labour market programmes and activation strategies that are now widely seen as at the core of anti-poverty policies (see for example OECD 2009, European Commission 2013). These have been the subject of a very substantial research literature, covering the evaluation of the impact of specific interventions and of active labour market policies more broadly - for reviews see for example Heckman, Lalonde and Smith, (1999), OECD (2005, 2007b), Card, Kluve and Weber (2010), Kluve (2010). The general thrust of these evaluations, when carried out rigorously, was not particularly positive for a time - as reflected in for example Richard Freeman's summary that "Random assignment social experiments analysed with care .... have shown us that one favourite solution to labour market problems-training and other active labour market measures - have at best only modest effects on outcomes” (Freeman, 1998: 16). More recent evaluations have been more positive in tone, with OECD (2009) for example concluding that activation programmes can have a significant impact on unemployment. Card, Kluve and Weber's (2010) meta-analysis of microeconometric evaluations yields particularly interesting findings from both a substantive and methodological point of view. They find subsidized public sector employment programs to have the least favourable impact estimates, whereas job search assistance programs have relatively favourable short-run impacts, and classroom and on-the-job training programs tend to show better outcomes in the medium-run than the short-run, and programs for youths are less likely to yield positive impacts than untargeted programs. Methodologically, they find that - controlling for the outcome measure and the type of program and participants experimental and non-experimental studies have similar impact estimates, suggesting that the research designs used in recent non-experimental evaluations are unbiased. They also note that the outcome variable used to measure program effectiveness matters, with evaluations based on registered unemployment durations are more likely to show favourable short-term impacts. The outcome variable is also clearly very important from a poverty perspective: it cannot be taken for granted that success in terms of a transition from unemployment into employment, even if sustained, leads to an escape from poverty - since not all those benefitting may have been in poverty when unemployed, and for those who were the increase in income involved after taxes and withdrawal of benefits may not suffice to lift the household above a poverty threshold, as discussed at some length in Section 3 above. The rigorous evaluation of active labour market programmes in terms of their impact on poverty remains a major gap to be filled. 
As is noted in Card, Kluve and Weber's (2010), active labour market programmes are widely diverse. An effort to categorize these policies in relation to their political determinants is made by Bonoli (2012) on the basis of national variation across OECD economies, but he found little regularity over time in these determinants, with a mix of leftist and centrist political parties in each period advocating active labour market policies. Moreover, Bruno and Rovelli (2010) compare and document differences in labour market policies in EU countries in 2000's and find that in general higher rates of employment are associated with more expenditure on active labour market programs for countries with a larger share of the population embracing pro-work attitudes. Recently, an OECD (2013) study analysing activation programs in OECD countries and with more detail in Ireland, UK, Japan, Norway, Finland, Switzerland and Australia brings out the different responses of expenditures on activation programs after the economic crisis, finding it difficult to establish a common pattern.

\subsection{Intergenerational Transmission, Childhood and Neighbourhoods}

The intergenerational transmission of poverty and disadvantage continues to be a core concern both for research and policy. Research on income mobility across the distribution is the topic of Chapter 11 by Jäntti and Jenkins, but here it is important to reiterate that there is substantial evidence from country-specific studies that mobility is particularly limited towards the bottom of the socioeconomic hierarchy, so that poverty is to a significant degree inherited across generations. Examples from research in the United States include Wilson (1987), Gottschalk et al. (1994), Duncan, Brooks-Gunn and Klebanov (1994), Duncan and Brooks-Gunn (1997), Duncan et al. (1998), and Corcoran (2001); for Canada, see Corak (2001); recent U.K. studies include Sigle-Rushton (2004) and Blanden and Gibbons (2006), and similar studies that trace current poverty or disadvantage to conditions in childhood exist for other rich countries. The likelihood of welfare recipiency is also seen to be associated across generations - see for example Corak (2004) for Sweden and Canada and Page (2004) for the United States.

OECD (2009) concludes that variation in the strength of transmission of poverty across countries cannot reliably be assessed with the available evidence. However, the findings of Jäntti et al. (2006) showing considerably greater upward mobility in individual earnings from the bottom quintile in the Scandinavian countries than in the United Kingdom and especially the United States, and those of Raum et al. (2007) that the intergenerational 
transmission of family earnings is also significantly stronger in the UK and even more so the USA than in the Scandinavian countries, are suggestive (see also Aaberge et al., 2002). Furthermore, recent studies by Esping-Andersen and Wagner (2010) and Whelan, Nolan and Maitre (2013) have been able to exploit the availability of harmonised data from a special module on intergenerational transmission attached to EU-SILC in 2005. Esping-Andersen and Wagner estimate the impact of economic hardship during childhood on both educational attainment and adult income (controlling inter alia for lone motherhood and parents' education) in Denmark, Norway, France, Italy, Spain, and the United Kingdom. They conclude that economic hardship in childhood has no direct effects on adult income in any of the countries, but does have powerful indirect effects via children's educational attainment; this effect disappears among the youngest cohorts in both Denmark and Norway but not in the other countries, leading the authors to conclude that the Scandinavian countries are more recently succeeding in minimising the adverse consequences of economic want in childhood. This is consistent with Whelan, Nolan and Maitre's study, which included a broader range of EU countries and found that factors such as parental class, parental education, and childhood economic circumstances/hardship had less influence on both income poverty and a broader, multidimensional measure of vulnerability in social democratic countries than in countries in the liberal and southern European welfare regimes.

Understanding the mechanisms at work is clearly vital in designing strategies aimed at reducing the extent to which poverty is handed down from one generation to the next, and both causal channels and policy responses have been the subject of substantial bodies of literature (for reviews see Esping-Andersen, 2004a, 2004b; D’Addio, 2007; Nolan et al., 2011). Studies focused on the United States show that the inheritance of poverty is connected with substantially less schooling (on average, poor children will have two years less schooling than non-poor children), poor health, and crime (Mayer, 1997; Duncan and Brooks-Gunn, 1997), and similar if less dramatic effects have been documented for the United Kingdom (Gregg et al., 1999) and France (Maurin, 2002; CERC, 2004). Gregg et al.’s (1999) study controls for the child's abilities (via cognitive test scores at age seven), and still finds strong poverty effects. US and British studies demonstrate strong negative effects of lone motherhood on child outcomes, but also suggest that the main reason has to do with poor economic conditions (McLanahan and Sandefur, 1994; Biblarz and Raftery, 1999, Gregg et al., 1999), while selection into lone parenthood may also be a factor (Piketty, 2003). Interestingly, Esping-Andersen and Wagner's (2010) multi-country study found no 
significant effects of lone motherhood on educational attainment or adult income having controlled for mother's education and childhood financial hardship.

The impact of genes/nature versus nurture and the interactions between them have been the topic of much debate in the broader intergenerational mobility literature, as discussed in Jäntti and Jenkins' chapter. (See also Chapter 18 by Deaton for a detailed discussion on health and inequality). From the point of view of transmission of poverty and disadvantage, the key thrust of recent findings is that cognitive skills and family finances matter, but so do non-cognitive abilities, social skills, cultural resources, motivation and, more generally, the familial 'learning milieu': cognitive and non-cognitive skills are influenced by family endowments that are neither strictly financial or genetic. Heckman and Lochner (2000), Carneiro and Heckman (2003) have been influential studies, with their 'learning-begets-learning' model stressing the fundamental causal importance of conditions in the pre-school years, especially those related to behavioural and cognitive development. There is a growing consensus in the literature that conditions when children are under age 6, or even 3, are decisive for their cognitive skills, sense of security, and ability and motivation to learn (Danziger and Waldfogel, 2000; Duncan and Brooks-Gunn, 1997). Substantial differences in children's cognitive abilities by parents' socio-economic status emerge at early ages and carry through to subsequent achievements in education and earnings (e.g. Cunha and Heckman, 2007); poverty in early childhood has strong adverse effects on these later outcomes, partly because of parental traits such as poor cognitive and non-cognitive skills and the effects of family 'culture', in particular in terms of how it influences parenting behavior and child stimulation (de Graaf et al., 2000; Esping-Andersen, 2007).

This has significantly influenced thinking about the role of education in seeking to reduce intergenerational transmission of poverty. Mounting evidence suggests that differences in the design and financing of education systems per se seem to matter rather less than had been thought. There appears to be a broad consensus that early tracking according to ability reduces educational mobility across generations (see for example Hanushek and Woessmann, 2006), with the abolition of early tracking and the introduction of comprehensive school systems seen to have boosted educational attainment among the least privileged social strata in Sweden, Finland and Norway. Since these are also countries in which welfare state redistribution increased substantially over the same period, it is difficult to identify how much it was education reform or income equalization that produced higher mobility. However, Blanden et al.’s (2005) UK analyses suggest that education reform which delayed tracking produced a substantial increase in inter-generational mobility there, 
primarily to the benefit of children from low income families, which cannot be ascribed to an increase in welfare state redistribution since over the period in question income inequality actually grew. More broadly, though, it has become increasingly clear that generalised policies promoting the attainment of higher levels of education by increasing the proportion going on to third level - assigned a central role in strategies aimed at improving equality of opportunity in many countries - may not be adequate if the aim is to address the disadvantages that children from poorer backgrounds face from the outset.

This has served to reinforce the emphasis in recent literature arguing for an early childhood focus, and that high quality early childhood programmes can significantly improve both cognitive and non-cognitive outcomes for disadvantaged children (Currie, 2001; Carneiro and Heckman, 2003; Karoly et al., 2005; Waldfogel, 2006). Heckman’s work has been particularly influential in demonstrating that investing in early childhood is a costeffective policy (though the broader implications in terms of later interventions have been hotly debated). The core evidence that underpins Heckman's work comes from early intervention programs in the US, but Esping-Andersen (2004) relates the significant decline in social inheritance effects for the Nordic countries to the introduction of universal, highquality child care. Schutz et al (2005) in their cross-sectional comparison across countries report an inverted U-shaped relationship between family background effect and pre-school enrolment, which suggests that early education may reduce the extent to which family background shapes life-chances. OECD (2009) concludes that good quality care in early childhood, pre-school and also school years, are essential tools for promoting intergenerational mobility.

Going beyond education, the extent and nature of the welfare state itself can clearly affect the intergenerational transmission of poverty, indeed this is often articulated as a core aim in terms of equalizing children's life chances and avoiding wasted potential. One might expect that social policies that reduce child poverty (such as effective income support and promoting maternal employment, as discussed earlier - see for example UNICEF, 2007, Whiteford and Adema, 2007) would also promote more inter-generational inequality, but directly demonstrating that link is less straightforward. Mayer (1997), for example, argued that low income in itself is less important than parental characteristics such as low skills, poor health, or deviance which affect the likelihood of being poor. In a comparison across US states, though, Mayer and Lopoo (2008) find that in high-spending states the difference in mobility between advantaged and disadvantaged children is smaller than in low-spending ones. It has been calculated that the risk of child poverty falls by a factor of four when 
mothers are employed (Esping-Andersen, 2009). There is also some evidence that intergenerational transmission of welfare dependency may be related to programme design, with Corak et al.'s (2004) comparison of cash support schemes in the USA and Sweden suggesting that passive programmes are more likely to promote the transmission of welfare dependency than active ones. More generally, benefit systems that rely heavily on means-testing are more likely to create the poverty and unemployment traps that make it more likely that poverty and welfare dependency persist into subsequent generations.

Finally, still focusing on children and the transmission of poverty, an issue that has received considerable attention in the research literature is the potential effect of living in a "bad" neighbourhood. Some studies suggest that local conditions can help explain the intergenerational transmission of income (OECD 2008), though their impact may be relatively weak even in the USA. The range of US-focused studies reported in for example Brooks-Gunn, Aber and Duncan (1997) suggested that neighbourhood does matter for child and youth development, having greatest impact in early childhood and late adolescence and less in between, but the size of these effects was usually much smaller than those of familylevel conditions. Solon, Page and Duncan (2000) used the cluster sampling design of the Panel Study of Income Dynamics to estimate both sibling and neighbourhood correlations of years of schooling, and found sibling correlations of around 0.5 , whereas their neighbourhood estimates were as low as 0.1. Raaum, Salvanes, and Sorensen (2003) used Norwegian census data and concluded likewise that neighbourhood correlations were small compared to sibling correlations, both for educational attainment and long-run earnings. This is consistent with the findings of US experiments where families living in public housing were assigned housing vouchers by lottery encouraging them to move to neighbourhoods with lower poverty rates; the results reported in Sanbonmatsu et al. (2006) show no significant effects on test scores. Looking beyond educational attainment to a broader set of poverty-related outcomes, the difficulties in adequately characterising neighbourhoods in terms of all their potentially relevant characteristics, and of distinguishing their effects on poverty and related outcomes from those of individual/family characteristics - taking into account that there may be interactions between them - have also been emphasised in research outside the USA (see for example Lupton, 2003). 


\section{Section 4: The Welfare State, Anti-Poverty Policy and the Economic Crisis of the Late 2000s}

\subsection{Poverty, Income Inequality and the Economic Crisis}

The economic crisis experienced by the OECD countries since 2007-2008 has been the most serious since the Great Depression of the 1930s in terms of its impact on output and growth, and is central to the ways in which poverty and anti-poverty policies are now being thought about, studied and debated. The crisis has impacted on poverty directly, as we will discuss, but also has altered the context in which welfare states are currently operating and perspectives on how they are and should be evolving in the medium-term. Here we look first at the evidence on the immediate impact of the crisis, and then at the medium-term context for anti-poverty policy.

The immediate impact of the crisis on income inequality and poverty has been the subject of a number of national and comparative studies, including Matsaganis and Leventi (2013), Callan, Nolan and Walsh (2011), Immervoll, Peichl and Tatsiramos (2011), Figari, Salvatore and Sutherland (2011) and Jenkins, Brandolini, Micklewright and Nolan (2013). Jenkins et al. adopt a comparative perspective, looking at aggregate indicators across the OECD and at six case-study countries in depth. Their central conclusion is that the immediate impact of the crisis on income inequality and income poverty in most countries was much more modest than the dramatic experience of the Great Depression, although not so different from some more recent recessions such as the Nordic crisis of the early 1990s. They stress that a striking feature of the crisis from 2007-8 has been the extent to which its macroeconomic impact varied across countries: in some there were major declines in economic activity and sharply rising unemployment, but in others much more modest changes in growth and employment (on which see also Lane and Milesi-Ferretti, 2012). The peak-to-trough fall in quarterly GDP was substantially larger than the average fall during recessions over the previous 50 years almost everywhere, but ranged nonetheless from zero in Australia to nearly 13 per cent in Ireland. Another feature highlighted is that GDP declines were not fully transmitted into falls in the real disposable income of households, which were protected by both automatic stabilisers and additional support of governments through the tax and benefit system. The immediate response of employment to the fall in GDP was also frequently smaller than in previous recessions, though this was not the case in countries such as Ireland, Spain, and the USA where a boom-bust pattern in the housing market played an important role in the recession. Large falls in individual employment were also accompanied 
by significant rises in household worklessness in countries such as Ireland, Spain and the USA, but not in some others - notably Denmark and Finland - where the workless household rate fell despite relatively large increases in the individual non-employment rate, cushioning the impact on poverty. Another feature of the immediate onset of the crisis was the decline in income from capital, concentrated among richer households.

Looking at available poverty indicators up to 2009 compared with pre-crisis, Jenkins et al found that relative income poverty rates typically fell in European countries, whereas absolute poverty rates (i.e. using 'anchored' income thresholds indexed to prices) tended to fall slightly in Europe while rising modestly in the USA (as measured with the US official poverty line), but in both cases these rates fell for the elderly. The six countries they studied in detail - Germany, Ireland, Italy, Sweden, the UK, and the USA - experienced differing macroeconomic shocks, with Germany recovering very rapidly, Sweden seeing a large decline in GDP but relatively rapid recovery, the USA experiencing marked contraction followed by some recovery, Italy and the UK seeing major downturns and Ireland experiencing the largest GDP decline among OECD countries. Germany saw little change in employment, whereas in Ireland and the USA at the other extreme unemployment rose rapidly. The short-run impact on household income inequality and poverty was relatively modest. In Germany, the proportion of persons with a household income less than 60 per cent of the contemporary median income declined marginally, and the proportion in households below such an income threshold held fixed in purchasing power at its 2007 level also fell. Chapter 3 shows that median income, inequality and relative poverty all rose slightly in 2010. In the UK, the number falling below 60 per cent of median income fell by more than one percentage point and a fixed real threshold showed a larger decline in poverty. In Sweden, the proportion falling below 60 per cent of median income increased, although when a threshold fixed in purchasing power terms is employed the increase was a good deal smaller. In Ireland, relative income poverty declined between 2007 and 2009 while the proportion below a fixed real income threshold remained stable. In Italy the buffering role of social transfers was relatively limited, although the consequent increase in poverty might be considered modest given the scale of the initial macroeconomic shock. Finally, in the USA the relative poverty rate declined modestly, reflecting a decline in real median income, whereas the official poverty rate (calculated using a low-income cut-off held fixed in real terms) increased. In all six case study countries, elderly people were relatively well protected, compared with children and individuals of working age. 
The variation in the distributional impact of the crisis to date across countries reflects not only differences in the nature of the macroeconomic downturn but also differences in how cash transfers and direct taxes cushioned household net incomes from the full effects of what was happening to market incomes. To some extent, these are differences in automatic stabilisation and so vary with the generosity and comprehensiveness of social safety-nets and the structure and levels of direct taxes and social insurance contributions. But policy responses and choices as the recession impacted have also been important.

More recent poverty indicators for European countries produced by Eurostat, up to 2011, also show that experiences have been quite varied. As shown in Table 5, between 2007 and 2011 the proportion falling below 60\% of median income rose by 1 percentage point or more in 8 countries, fell by that amount in 7 , and was stable in the rest. The average relative income poverty rate across the EU 27 was $16.5 \%$ in 2007 and 16.9 in 2011 . Income poverty rates 'anchored' at the 2008 60\% of median threshold and then indexed to prices showed a good deal more variability over time across EU countries, as Table 6 shows. This rose in 13 countries, sometimes by a remarkably large amount - by 11 percentage points in Latvia and Lithuania and almost 14 percentage points in Iceland; however, it fell in another 10 countries, so that the overall average across the EU rose only from $16.4 \%$ to $17.5 \%$. It is interesting to compare this with the trend in material deprivation over the same period, as measured by the EU's severe material deprivation indicator: Table 7 shows that this rose between 2008 and 2011 in 13 countries while falling in 6; the average across the EU rose marginally. Among countries particularly hard-hit by the crisis deprivation rose sharply in Ireland, Spain, Greece and Italy, as well as Latvia and Lithuania, but fell in Portugal.

\subsection{The Crisis and Anti-Poverty Policy in the Medium Term}

The immediate impact of the onset of the crisis from 2007-8 on living standards and poverty was cushioned, at least to some extent, by welfare state institutions and in particular by social protection and tax systems. The medium-term impact of the crisis on poverty depends not only on developments in the macroeconomy and in employment, but also on the policies adopted with respect to the welfare state broadly conceived and to transfers most particularly, and the effects of the crisis on the public finances are dominant in framing the context in which these choices are being made. The need - or perception of such a need - to consolidate public finances plays a central role in debates about responding to the crisis, with tackling poverty often relegated to a more modest role, and this could lead to changes to 
welfare state systems and parameters that will take many years to work their way through, continuing to impact on poverty long after economic growth has resumed and the recession is considered to have ended from a purely macroeconomic perspective. (The fairness of fiscal consolidation programmes may itself affect the likelihood of them being successful, as analysed by Kaplanoglou, Raponos and Bardakas (2013) for 29 OECD countries over the period 1971-2009; their results suggest that programmes improving the targeting of social transfers and their effectiveness in poverty alleviation, increasing spending on training and active labour market policies, and even reducing value-added taxes on necessities, enhance the probability of successful adjustment while promoting social cohesion.)

The variation across countries in the impact of the economic crisis on poverty reflects not only differences in the nature of the macroeconomic downturn but also differences in how cash transfers and direct taxes cushioned household net incomes from the full effects of what was happening to market incomes. To some extent, these are differences in automatic stabilisation and so vary with the generosity and comprehensiveness of social safety-nets and the structure and levels of direct taxes and social insurance contributions, as brought out in Dolls, Fuest, and Peichl's (2011, 2012) cross-country comparisons based on simulating taxbenefit models. However, policy choices as the recession impacted have also been important (for more discussion of EU governments’ initial responses, see Marchal, Marx, and Van Mechelen 2014). It is also worth emphasising that conventional income-based poverty measures may well miss some of the most important effects of 'austerity', since 'non-cash' income from government services and the impact of increases in indirect taxation are not captured.

In such a context, the pressure to increase the targeting of cash transfers is likely to intensify, although that can run the risk of worsening poverty and unemployment 'traps' and undermining the bases for social solidarity and political support for relatively generous provision. The notion of 'social investment' has come to play a major part in debates about the role of social spending and the future of welfare states in the rich countries, particularly in Europe where the language of social investment has become embedded in European Union discourse since the adoption of the Lisbon Agenda in 2000. A number of important recent contributions have highlighted its potential as a new perspective on or paradigm for social policy in the context of the economic crisis and to the demand of the knowledge-based economy more broadly, as an alternative to neoliberal responses focusing on retrenchment in social spending, and as a key ingredient in responding to the macroeconomic/Euro crisis (see for example the contributions to Morel, Palier and Palme, 2011, Vandenbroucke, Hemerijck 
and Palier, 2011, and Hemerijck and Vandenbroucke, 2012) Others have sought to assess the extent to which recent directions in social policies and spending patterns could be characterised as moving towards a social investment strategy, and whether disappointing outcomes in terms of poverty can be seen as a failure of such a strategy (Cantillon, 2011; Vandenbroucke and Vleminckx, 2011; Van Kersbergen and Hemerijck, 2012). The EU is paying serious attention to this debate, as evidenced by the establishment by DG Employment, Social Affairs and Equal Opportunities of an expert group on Social Investment for Growth and Cohesion in autumn 2012 as input to a major initiative envisaged in the area of social policies.

'Social investment' may be viewed in a number of distinct ways, as Nolan (2013) discusses: as a paradigm and strategy for social policies and spending, as a conceptual base and analytical framework, and/or as a platform for political engagement in both a narrow and broad sense. Whether social investment can credibly be presented as the paradigm most likely to underpin economic growth or employment is open to debate and merits further research, even if - as Nolan (2013) argues - the distinction between social 'investment' and other social spending is not particularly robust, conceptually and empirically. Highlighting that distinction may not in any case be the most useful and productive way to frame the debate about the future of social spending, where concentration on a narrow economic argument runs the risk of obscuring normative choices and the broader case for social spending.

Finally, it is important to note that an economic crisis of the depth and nature of the one which began in 2007-8 may also have major implications for intergenerational equity, especially if it continues to be the case that the elderly are relatively well-cushioned from its effects compared to younger people; sustained high unemployment in particular may well result in long-term 'scarring' of those affected, with the risk that their disadvantage is transmitted to the next generation.

\section{Section 5: Future Research Directions}

We conclude with a brief discussion of priorities for research on poverty and antipoverty policy. The key challenges lie in deepening understanding of the processes at work in creating and perpetuating poverty at individual, household, national and cross-national level. While much has been learned about the characteristics associated with poverty in different countries, the fact that this differs so widely across countries provides a window into the nature of the underlying processes that has not been fully exploited. In the same vein, 
studying the factors associated with change over time in a specific country is valuable but putting these changes in a comparative perspective adds another dimension. So a panel of countries approach has increasing potential as the statistical underpinning in terms of comparable data continues to be built. This can be complemented by continued development of the potential to carry out micro-simulation analysis in a comparative perspective; the challenge of incorporating behavioural responses into such analysis remains substantial (Immervoll et al., 2007). Exploiting the potential of panel data will continue to be a priority, for example to reliably distinguish those genuinely and persistently on low income, and understanding the barriers to income smoothing facing those on low income more transiently. Increasing recognition of the multi-dimensional nature of poverty and social exclusion points to the need to deepen understanding of the linkages between different forms of deprivation and exclusion, moving beyond descriptive analysis of the extent to which they go together to study the processes that underpin the underlying relationships between them - where once again a comparative perspective is invaluable - while also addressing the difficult conceptual issues involved.

There also remains a substantial research agenda in the field of anti-poverty policy. Not many countries have made very substantial progress in reducing relative poverty as conventionally measured in recent years, though material deprivation and absolute poverty have generally declined up to the crisis from 2008. While some progress has been made in understanding the factors at work, many of the deeper causal questions remain largely unsettled. Changes in the distribution of income from the market may have made reducing relative poverty more difficult, and the redistributive impact of tax and benefit systems may have declined, and each needs to be much better understood. A key question is whether the apparent failure of many governments to maintain or to improve the anti-poverty impact of their tax and benefit systems is a consequence of lack of effective political will (voter preferences) or reflects instead (or as well) systemic limits and/or external constraints. Important items on the policy research agenda include:

- Can more be done with less? There is a continuing controversy over targeting and cost-effectiveness of public social expenditure. With ageing populations and rising needs due to socio-demographic and economic trends, this question is bound to remain at the forefront of the research agenda.

- Why are anti-poverty provisions in many countries so manifestly inadequate? Are there systemic limits to incrementalism in redistributive policy? That is to say: are 
there really limits to what improvement can be achieved by strengthening the existing main pillars of redistribution: wage and broader market force regulation, social insurance, social assistance and taxes? What promise do new redistributive mechanisms and programs offer? Negative income taxes and associated systems are seen as the way forward by some but short-term issues such as take-up and longerterm effects on wages and human capital formation, earnings mobility etc. are not well-understood.

- What is the optimal balance between direct redistribution and 'social investment', i.e. expenditures that seek to generate lasting effects through improvements in skills and capabilities? To what extent can social investment act as a substitute for direct 'compensatory' redistribution, or is there complementarity? If so, what is the optimal balance?

- Making cash benefits and services conditional on certain behavioural requirements and conditions is a policy strategy that is gaining increased attention, part of a broader current towards more micro-intervention in social policy, informed by social experiments. Is such a shift from the macro to the micro-level really the way forward, and what, if any, are the limits there?

Finally, we should note that while this survey has focused on the 'rich world' (as it is conventionally understood), some of the most innovative anti-poverty policy is being conceived, implemented and analysed outside of that area, with a number of South American and Asian countries standing out in this respect. An important task for future research is to integrate these rich but largely parallel streams of poverty research. 


\section{References}

Aaberge, R., Björklund, A., Jäntti, M., Palme, M. Pedersen, P., Smith, N. and Wennemo, T. (2002). "Income Inequality and Income Mobility in the Scandinavian Countries Compared to the United States”, Review of Income and Wealth, 48(4), 443-69.

Aaberge, R. and Langørgen, A. (2006). "Measuring The Benefits From Public Services: The Effects Of Local Government Spending On The Distribution Of Income In Norway”, Review of Income and Wealth, 52(1), 61-83.

Aaberge, R., Bhuller, M., Langørgen, A. and Mogstad, M. (2010). "The distributional impact of public services when needs differ”, Journal of Public Economics, 94(9-10), 549-562.

Aaberge, R. and Peluso, E. (2012). A Counting Approach for Measuring Multidimensional Deprivation. IZA Discussion Papers 6589. Bonn: Institute for the Study of Labor (IZA).

Aaberge, R. and Mogstad, M. (2012). Inequality in current and lifetime income. Discussion Papers 726, Research Department of Statistics Norway.

Aaberge, R. and Flood, L. (2013). U.S. versus Sweden: The Effect of Alternative In-Work Tax Credit Policies on Labour Supply of Single Mothers. IZA Discussion Papers 7706. Bonn: Institute for the Study of Labor (IZA).

Adema, W., Fron, P. and Ladaique, M. (2011). Is the European Welfare State Really More Expensive? Indicators on Social Spending, 1980-2012; and a Manual to the OECD Social Expenditure Database (Socx). OECD Publishing.

Airio, I. (2008). Change of Norm? In-Work Poverty in a Comparative Perspective, Studies in Social Security and Health, 92, Kela Research Department, Helsinki: Kela.

Allègre, G. and Jaehrling, K. (2011). 'Making work pay for whom? : tax and benefits impacts on in-work poverty', in Working poverty in Europe: a comparative approach, edited by N. Fraser, R. Gutiérrez, R. Peña-Casas, pp. 278-303. Basingstoke: Palgrave Macmillan.

Andreß, H.-J. and Lohmann, H. (2008). The Working Poor in Europe: Employment, Poverty and Globalization. Cheltenham: Edward Elgar.

Arza, C. and Kohli, M. (2008). Changing European welfare: The new distributional principles of pension policy. New York: Routledge.

Ashenfelter O. and Layard, R. (1987). Handbook of Labor Economics, edition 1, volume 2. Amsterdam: Elsevier-North Holland.

Ashenfelter, O. and Card, D. (1999). Handbook of Labor Economics, edition 1, volume 3. Amsterdam: Elsevier-North Holland.

Ashenfelter. O. and Card, D. (2011). Handbook of Labor Economics. edition 1, volume 4. Amsterdam: Elsevier-North Holland.

Atkinson, A B. (1987). “On the Measurement of Poverty”, Econometrica, 55(4), 749-64.

Atkinson, A.B. (2003). "Multidimensional Deprivation: Contrasting Social Welfare and Counting Approaches”, Journal of Economic Inequality, 1(1), 51-65.

Atkinson, T., Cantillon, B., Marlier, E. and Nolan, B. (2002). Social indicators: the EU and social inclusion. Oxford: Oxford University Press. 
Atkinson, A.B. and Marlier, E. (2010). Income and Living Conditions in Europe. Luxembourg: Eurostat.

Atkinson, A., Rainwater, L. and Smeeding, T. (1995). Income Distribution in OECD Countries. Paris: OECD.

Bane M. J. and Ellwood, D. (1986). "Slipping in and Out of Poverty: the Dynamics of Poverty Spells”, The Journal of Human Resources, 12, 1-23.

Barbier, J.-C. and Ludwig-Mayerhofer, W. (2004). "Introduction: the many worlds of activation”, European Societies, 6(4), 423-36.

Bargain, O. and Orsini, K. (2006). "In-work policies in Europe: Killing two birds with one stone?”, Labour Economics, 13(6), 667-697.

Barth, E. and Moene, K. (2009). The Equality Multiplier. NBER Working Paper 15076. Cambridge Massachusetts: National Bureau of Economic Research.

Bastagli, F. (2011). “Conditional Cash Transfers as a Tool of Social Policy”, Economic \& Political Weekly, XLVI, 61-66.

Becker, G. (1964). Human Capital: A Theoretical and Empirical Analysis, with Special Reference to Education. Chicago: University of Chicago Press.

Bekker, S. and Wilthagen, A.C.J.M. (2008). "Flexicurity: A European approach to labour market policy”, Intereconomics: Review of European Economic Policy, 43(2), 68-73.

Benedict, M.E. and Shaw, K. (1995). "The Impact of Pension Benefits on the Distribution of Earned Income”, Industrial and Labor Relations Review, 48(4): 740-757.

Beramendi Alvarez, P. (2001). The Politics of Income Inequality in the OECD. The Role of Second Order Effects. Luxembourg Income Study Working Paper No. 284.

Bergh, A. (2005). 'On the Counterfactual Problem of Welfare State Research: How Can We Measure Redistribution?’, European Sociological Review, 21(4), 345-357.

Biblarz, T. and Raftery, A. (1999). "Family Structure, Educational Attainment, and Socioeconomic Success: Rethinking the 'Pathology of Matriarchy”, American Journal of Sociology 105: 321-365.

Blanden, J., Gregg, P. and Machin, S. (2005). "Educational Inequality and Intergenerational Mobility”, in What's the Good of Education?, edited by S. Machin and A. Vignoles. Princeton: NJ: Princeton University Press.

Blanden, J. and Gibbons, S. (2006). The Persistence of Poverty across Generations: A View from Two Cohorts. Bristol: Policy Press.

Blau, F. and Kahn, L. (2008). 'Inequality and Earnings Distribution', in The Oxford Handbook of Economic Inequality, edited by W. Salverda, B. Nolan and T. Smeeding. Oxford: Oxford University Press.

Boarini, R. and Mira d'Ercole, M. (2006). Measures of Material Deprivation in OECD Countries. OECD Social, Employment and Migration Working Papers 2006(6). Paris: OECD.

Bonoli, G. (2007). "Time matters. Postindustrialisation, new social risks and welfare state adaptation in advanced industrial democracies”, Comparative Political Studies, 40, 495-520. 
Bonoli, G. (2010). “The political economy of active labour market policies”, Politics \& Society, 38.

Börsch-Supan, Axel H. (2012). Entitlement Reforms in Europe: Policy Mixes in the Current Pension Reform Process. NBER Working Paper No. 18009.

Bourguignon, F. and Chakravarty, S. (2003). "The Measurement of Multidimensional Poverty”, Journal of Economic Inequality, 1(1), 25-49.

Bourguignon, F. and Rogers, F. Halsey (2007). "Distributional effects of educational improvements: Are we using the wrong model?”, Economics of Education Review, 26(6), 735-746.

Bovenberg, L. and van Ewijk, C. (2011). The Future of Multi-Pillar Pension Systems. Netspar Discussion Papers DP 09/2011-079.

Bradshaw, J. (2010). An international perspective on child benefit packages, in From Child Welfare to Child Well-being: An international perspective on knowledge in the service of policy making, edited by S. Kamerman, S. Phipps and A. Ben-Arieh, pp. 293-307. Springer.

Bradshaw, J. and Finch, N. (2002). A comparison of Child Benefit packages in 22 countries, Research Report 174. Norwich: Department for Work and Pensions.

Bradshaw, J., et al. (2008). A minimum income standard for Britain. What people think. York: Joseph Rowntree Foundation.

Brooks-Gunn, J., Duncan, G.J. and Aber, J. L. (1997). Neighborhood Poverty, Vol. 1: Context and Consequences for Children. New York: Russell Sage Foundation.

Bruno, R. and Rovelli, R. (2010). "Labour Market Policies and Outcomes in the Enlarged EU”, Journal of Common Market Studies, 48, 661-685.

Burtless, G. (2006). "Poverty and Inequality”, in The Oxford Handbook of Pensions and Retirement Income, edited by G.L. Clark, A.H. Munell and J.M. Orszag. Oxford: Oxford University Press.

Burtless, G. (2009). "Demographic transformation and economic inequality" in The Oxford Handbook of Economic Inequality, edited by W. Salverda, B. Nolan and T.M. Smeeding. Oxford: Oxford University Press.

Burniaux, J-M., Dan, T-T., Fore, D., Förster, M., Mira d'Ercole, M. and Oxley, H. (1998). Income distribution and poverty in selected OECD countries. OECD Economics Department Working Paper 189. Paris: OECD.

Burniaux, J-M. and Mira d'Ercole, M. (2006). Labour Market Performance, Income Inequality and Poverty in OECD Countries. OECD Economics Department Working Paper 500. Paris: OECD.

Buhmann, B., Rainwater, L., Schmaus G. and Smeeding, T. (1987). “Equivalence Scales, well-Being, Inequality and Poverty: Sensitivity estimates Across Ten Countries Using the Luxembourg Income Study (LIS) Database”, Review of Income and Wealth, 34, $115-42$.

Callan, T. and Keane, C., (2009). "Non-cash Benefits and the Distribution of Economic Welfare", The Economic and Social Review, Economic and Social Studies, 40(1), 4971. 
Callan, T., Nolan, B. and Walsh, J. (2011). "The Economic Crisis, Public Sector Pay, and the Income Distribution”, in Research on Labor Economics, v. 32, edited by H. Immervoll, A. Peichl, K. Tatsiramos, pp. 207-225. Bingley: Emerald.

Callan, T., Smeeding, T. and Tsakloglou, P. (2008). "Short-run distributional effects of public education transfers to tertiary education students in seven European countries", Education Economics, 16(3), 275-288.

Caminada, K., Goudswaard, K. and Wang, C. (2012). Disentangling Income Inequality and the Redistributive Effect of Taxes and Transfers in 20 LIS Countries Over Time. LIS Working Paper Series Luxembourg Income Study (LIS) No. 581.

Caminada, K., Goudswaard, K. and Van Vliet, O. (2010). "Patterns of Welfare State Indicators in the EU: Is There Convergence?”, Journal of Common Market Studies, 48, 529-556.

Cantillon, B. (2011). “The Paradox of the Social Investment State: Growth, Employment and Poverty in the Lisbon Era”, Journal of European Social Policy, 21(5), 432-449.

Cantillon, B., Marx, I. and Van den Bosch, K., (2003). "The puzzle of egalitarianism: the relationship between employment, wage inequality, social expenditure and poverty", European Journal of Social Security, 5(2), 108-127.

Cantillon, B., Van Mechelen, N., Pintelon, O. and van den Heede, A. (2014). "Social redistribution, poverty and the adequacy of social protection in the EU", in Reconciling work and poverty reduction: how successful are European welfare states?, edited by B. Cantillon and F. Vandenbroucke, pp. 157-184. Oxford: Oxford University Press.

Card, D. (1999). “The Causal Effect of Education on Earnings”, in Handbook of Labor Economics, vol. 3, edited by O. Ashenfelter and D. Card. Amsterdam: Elsevier-North Holland.

Card, D., Kluve, J. and Weber, A. (2010). “Active Labor Market Policy Evaluations: A MetaAnalysis”, The Economic Journal, 120, F452-F477.

Card, D.; Heining, J. and Kline, P. (2013). "Workplace heterogeneity and the rise of West German wage inequality”, The Quarterly Journal of Economics, 128(3), 967-1015.

Carneiro, P., and Heckman, J. (2003). "Human Capital Policy”, in Inequality in America, edited by J. Heckman and A. Krueger. Cambridge, MA: MIT Press.

CERC (2004). Child Poverty in France. Paris: Conseil de L'Emploi, des Revenues et de la Cohesion Sociale.

Checchi, D., van de Werfhorst, H., Braga, M. and Meschi, E. (2014). "The Policy Response: Education", in Changing Inequalities and Societal Impacts in Rich Countries: Analytical and Comparative Perspectives, edited by W. Salverda, B. Nolan, D. Checchi, I. Marx, A. McKnight, I. Tóth and H. van de Werfhorst. Oxford: Oxford University Press.

Chetty, R. (2009). "Sufficient Statistics for Welfare Analysis: A Bridge Between Structural and Reduced-Form Methods", Annual Review of Economics, Annual Reviews, 1(1), 451-488.

Chetty, R., Friedman, J.N. and Saez, E. (2013). Using differences in knowledge across neighborhoods to uncover the impacts of the EITC on earnings. NBER Working Paper 18232. 
Citro, C. and Michael, R. (1995). Measuring Poverty: A New Approach. National Research Council, National Academy Press: Washington DC.

Corak, M. (2001). Are the Kids All Right? Intergenerational Mobility and Child Well-being in Canada. Analytical Studies Branch Research Paper Series 2001171e. Ottawa: Statistics Canada.

Corak, M., (2004). "Generational Income Mobility in North America and Europe: an introduction”, in Generational Income Mobility in North America and Europe, edited by M. Corak. Cambridge: Cambridge University Press.

Corak, M., Lietz, C. and Sutherland, H. (2005). The Impact of Tax and Transfer Systems on Children in the European Union. IZA Discussion Paper 1589. Bonn: Institute for the Study of Labor.

Corcoran, M. (2001). "Mobility, Persistence, and the Consequences of Poverty for Children: Child and Adult Outcomes", in Understanding Poverty, edited by S. Danziger and R. Haveman. Russell Sage Foundation and Harvard University Press.

Corluy, V. and Vandenbroucke, F. (2013). "Household joblessness", in Reconciling Work and Poverty Reduction. How successful are European welfare states?, edited by B. Cantillon and F. Vandenbroucke. Oxford: Oxford University Press.

Coulter, F., Cowell, F. and Jenkins, S. (1992). "Equivalence Scale Relativities and the Extent of Inequality and Poverty”, Economic Journal, 102, 1067-82.

Crettaz, E. (2011). Fighting Working Poverty in Post-industrial Economies. Causes, Tradeoffs and Policy Solutions. Cheltenham, UK and Northampton, MA, USA: Edward Elgar.

Cunha, F. and Heckman, J. (2007). “The Technology of Skill Formation”, American Economic Review, 97(2): 31-47.

Currie, J. (2001). "Early Childhood Intervention Programs", Journal of Economic Perspectives 15(2), 213-38.

Currie, J. and Gahvari, F. (2008). "Transfers in cash and in-kind: theory meets the data", Journal of Economic Literature, 46(2), 333-383.

D’Addio, Anna Christina (2007). Intergenerational Transmission of Disadvantage: Mobility or Immobility across Generations? A Review of the Evidence for OECD Countries. Social, Employment and Migration Working Papers No. 52. Paris: OECD.

Dang, T.-T., Immervoll, H., Mantovani, D., Orsini, K. and Sutherland, H. (2006). An Age Perspective on Economic Well-Being and Social Protection in Nine OECD Countries. IZA Discussion Papers 2173. Bonn: Institute for the Study of Labor (IZA).

Danziger, S., and Waldfogel, J. (2000). Securing the Future: Investing in Children from Birth to College. New York: Russell Sage Foundation.

Deacon, A. and Bradshaw, J. (1983). Reserved for the Poor: the Means Test in British Social Policy. Oxford: Robertson.

Deaton, A. (2010). “Instruments, Randomization, and Learning about Development”, Journal of Economic Literature 48, 424-455.

De Graaf, N.D., de Graaf, P. and Kraaykamp, G. (2000). "Parental Cultural Capital and Educational Attainment in the Netherlands: A Refinement of the Cultural Capital Perspective”, Sociology of Education, 73(2), 92-111. 
De Graaf-Zijl, M. and Nolan, B. (2011). "Household joblessness and its impact on poverty and deprivation in Europe”, Journal of European Social Policy 21(5), 413-431.

Dickens, R. and Ellwood, D.T. (2003). “Child Poverty In Britain And The United States”, Economic Journal, 2003, v113(488,Jun), F219-239.

Digeldey, I. (2007). "Between workfare and enablement - The different paths to transformation of the welfare state: A comparative analysis of activating labour market policies”, European Journal of Political Research, 46 (6), 823-851.

Dolls, M., Fuest, C. and Peichl, A. (2011). "Automatic Stabilizers, Economic Crisis and Income Distribution in Europe", in Who Loses in the Downturn? Economic Crisis, Employment and Income Distribution, edited by $\mathrm{H}$. Immervoll, A. Peichl, and K. Tatsiramo, pp. 227-55 (Research in Labor Economics, Volume 32). Bingley: Emerald Group Publishing Limited.

Dolls, M., Fuest, C. and Peichl, A. (2012). “Automatic Stabilizers and Economic Crisis: US vs. Europe”, Journal of Public Economicsn 96, 279-94.

Duclos, J.-Y. and Makdissi, P. (2005). Sequential Stochastic Dominance and the Robustness of Poverty Orderings”, Review of Income and Wealth, 51(1), 63-87.

Duncan, G.J. and Brooks-Gunn, J. (1997). Consequences of Growing Up Poor. New York: Russell Sage Foundation.

Duncan, G.J., Brooks-Gunn, J. and Klebanov, P.K. (1994). "Economic Deprivation and Early Childhood Development”, Child Development, 65(2), 296-318.

Duncan, G., Gustafsson, B., Hauser, R., Schmaus, G., Messinger, H., Muffels, R., Nolan, B. and Ray, J.-C. (1993). "Poverty Dynamics in Eight Countries”, Journal of Population Economics, 6(3), 215-234.

Duncan, G. J., Yeung, W. J., Brooks-Gunn, J. and Smith, J. R. (1998). "How much does childhood poverty affect the life chances of children?”, American Sociological Review, 63, 4-6-423.

Eichhorst, W., Gienberger-Zingerle, M. and Konle-Seidl, R. (2008). “Activation policies in Germany: From Status Protection to Basic Income Support”, in Bringing the Jobless into Work? Experiences with Activation Schemes in Europe and the US, edited by O. Eichhors, O. Kaufmann, and R. Konle-Seidl. Berlin: Springer.

Eissa, N. and Hoynes, H. (2004). "Taxes and the labor market participation of married couples: the earned income tax credit”, Journal of Public Economics, 88(9-10), 19311958.

Erikson, R. (1993). 'Descriptions in inequality: the Swedish approach to welfare research', in The Quality of Life, edited by M.C. Nussbaum and A. Sen. Oxford: Clarendon Press.

Esping-Andersen, G. (1990). The Three Worlds of Welfare Capitalism, Cambridge (UK): Polity Press.

Esping-Andersen, G. (1999). Social Foundations of Postindustrial Economies. Oxford: Oxford University Press.

Esping-Andersen, G., Gallie, D., Hemerijck, A. and Myles J. (2002). Why We Need a New Welfare State. Oxford: Oxford University Press. 
Esping-Andersen, G. (2004a). "Unequal Opportunities and the Mechanisms of Social Inheritance”, in Generational Income Mobility in North America and Europe, edited by Miles Corak. Cambridge: Cambridge University Press.

Esping-Andersen, G. (2004b). “Untying the Gordian Knot of Social Inheritance”, Research in Social Stratification and Mobility, 21: 115-39.

Esping-Andersen, G. (2007). “Sociological Explanations of Changing Income Distributions”, American Behavioural Scientist, 50(5): 639-58.

Esping-Andersen, G. and Wagner, S. (2010). Asymmetries in the Opportunity Structure: Intergenerational Mobility Trends in Scandinavia and Continental Europe. Department of Sociology Working Paper, Barcelona: UPF.

European Commission (2008). Employment in Europe. Luxembourg: Publications Office of the European Communities.

European Union (2013). Social Investment Package. Brussels.

Eurostat, (2005). Material deprivation in the EU, Statistics in Focus, Population and Social Conditions, 21/2005, Luxembourg: Statistical Office of the European Communities.

Ferrarini, T., and Nelson, K. (2003). "Taxation of Social Insurance and Redistribution: A Comparative Analysis of Ten Welfare States”, Journal of European Social Policy, 13(1), 21-33.

Ferrera, M. (1996). “The 'Southern Model' of Welfare in Social Europe”, Journal of European Social Policy, 6(1), 17-37.

Figari, F., Salvatori, A. and Sutherland, H. (2011). "Economic downturn and stress testing European welfare systems", in Who Loses in the Downturn? Economic Crisis, Employment and Income Distribution, edited by H. Immervoll, A. Peichl, and K. Tatsiramos, pp. 257-86. (Research in Labor Economics, Volume 32). Bingley: Emerald Group Publishing Limited.

Figari, F. and Sutherland, H (2013). "EUROMOD: The European Union Tax-Benefit Microsimulation Model”, Journal of Microsimulation, 6(1), 4-26.

Förster, M. and Pearson, M. (2002). "Income distribution and poverty in the OECD area: trends and driving forces”, OECD Economic Studies, (34), 7-39. Paris.

Förster, M and Mira d'Ercole, M. (2005). Income Distribution and Poverty in OECD Countries in the Second Half of the 1990s. OECD Social Employment and Migration Working Papers No. 22, Paris: OECD.

Foster, J., Greer, W.J. and Thorbecke, E. (1984). “A Class of Decomposable Poverty Indices”, Econometrica, 52, 761-6.

Fouarge, D. and Layte, R. (2005). "Welfare Regimes and Poverty Dynamics: The Duration and Recurrence of Poverty Spells in Europe”, Journal of Social Policy, 34, 1-20.

Fritzell, J. and Ritakallio, V.-M. (2004). Societal Shifts and Changed Patterns of Poverty. Luxembourg Income Study Working Paper No. 393. LIS: Luxembourg.

Fraser, N., R. Gutiérrez, and R. Peña-Casas (2011). Working Poverty in Europe: A Comparative Approach. Bakingstoke: Palgrave Macmillan.

Freeman, R. (1998). "War of the models: Which labour market institutions for the 21st century?”, Labour Economics 5, 1-24. 
Freeman, R. (2008). 'Globalization and Inequality', in The Oxford Handbook of Economic Inequality, edited by W. Salverda, B. Nolan and T. Smeeding. Oxford: Oxford University Press.

Garfinkel, I., Rainwater, L. and Smeeding, T. (2006). Wealth and Welfare States: Is America aLaggard or Leader? Oxford: Oxford University Press.

Giannelli, G.C., Jaenichen, U. and Rothe, T. (2013). Doing Well in Reforming the Labour Market? Recent Trends in Job Stability and Wages in Germany, IZA Discussion Paper No. 7580, Bonn: Institute for the Study of Labor.

Goedemé, T. (2013). "How much confidence can we have in EU-SILC? Complex sample designs and the standard error of the Europe 2020 poverty indicators", Social indicators research: an international and interdisciplinary journal for quality-of-life measurement, 110(1), 89-110.

Gottschalk, P., McLanahan, S.S. and Sandefur, G.D. (1994). "The Dynamics and Intergenerational Transmission of Poverty and Welfare Participation" in Confronting Poverty: Prescription for Change, edited by S.D. Danziger, G.D. Sandefur and D.H.Weinberg. Cambridge: Harvard University Press.

Gottschalk, P., and Smeeding, T. (1997). "Cross-National Comparisons of Earnings and Income Inequality”, Journal of Economic Literature XXXV: 633-687.

Gregg, P., Harkness, S. and Machin, S. (1999). Child Development and Family Income. York: Joseph Rowntree Foundation.

Gregg, P. Scutella, R. and Wadsworth, J. (2010). "Reconciling workless measures at the individual and household level. Theory and evidence from the United States, Britain, Germany, Spain and Australia”, Journal of Population Economics 23: 139-167.

Grogger, J. (2003). "The Effects Of Time Limits, The EITC, And Other Policy Changes On Welfare Use, Work, And Income Among Female-headed Families", Review of Economics and Statistics, 85(2), 394-408.

Grogger, J. (2004). "Welfare transitions in the 1990s: The economy, welfare policy, and the EITC”, Journal of Policy Analysis and Management, 23(4), 671-695.

Guio, A.-C. (2009). What can be learned from deprivation indicators in Europe? Eurostat methodologies and working paper, Luxembourg: Eurostat.

Guio, A.-C. and Maquet, E. (2007). "Material Deprivation and Poor Housing”, Comparative EU Statistics on Income and Living Conditions: Issues and Challenge, Eurostat, Luxembourg: Office for Official Publications of the European Communities.

Hanushek, E. and Woessmann, L. (2006). "Does Educational Tracking Affect Performance and Inequality? Differences-in-Differences Evidence across Countries”, The Economic Journal, 116, 510 (03), C63-C76.

Harding, A., Warren, N. and Lloyd, R. (2006). Moving Beyond Traditional Cash Measures of Economic Well-Being: Including Indirect Benefits and Indirect Taxes, NATSEM Discussion Papers, Issue 61/2006, Canberra: NATSEM.

Heckman, J.J. (2010). "Building Bridges between Structural and Program Evaluation Approaches to Evaluating Policy”, Journal of Economic Literature, 48(2), 356-98.

Heckman, J., Lalonde, R. and Smith, J. (1999). "The economics and econometrics of active labor market programs”, in Handbook of Labour Economics Vol. 3, edited by O. Ashenfelter and D. Car. Elsevier North Holland. 
Heckman, J. and Lochner, L. (2000). "Rethinking Education and Training Policy", in Securing the Future, edited by S. Danziger and J. Waldfogel. New York: Russell Sage Foundation.

Heckman, J.J. and Urzúa, S. (2010). "Comparing IV with structural models: What simple IV can and cannot identify”, Journal of Econometrics, 156(1), 27-37.

Hemerijck, A. and F. Vandenbroucke (2012). "Social Investment and the Euro Crisis: The Necessity of a Unifying Social Policy Concept”, Intereconomics, 47(4), 200-206.

Hills, J. (2002). “Comprehensibility and Balance: the Case for Putting Indicators in Baskets”, Politica Economica, 1, 95-8.

Holt, S. (2011). Ten Years of the EITC Movement: Making Work Pay Then and Now. Brookings Metropolitan Policy Program.

Holzmann, R. and Hinz, R. (2005). Old-Age Income Support in the 21st Century: The World Bank's Perspective on Pension Systems and Reform. Washington, DC: The World Bank.

Hotz, V.J. and Scholz, J. K. (2003). “The Earned Income Tax Credit', in Means-tested Transfer Programs in the U.S., edited by R. Moffit. University of Chicago Press.

Hoynes, H., Page, M. and Stevens, A. (2006). "Poverty in America: Trends and Explanations”, Journal of Economic Perspectives, 20: 47-68.

Imbens, G. (2010). "Better LATE Than Nothing: Some Comments on Deaton (2009) and Heckman and Urzua (2009)”, Journal of Economic Literature, 48(2), 399-423.

Immervoll, H., Levy, H., Lietz, D., Mantovani, D. and Sutherland, H. (2006). "The sensitivity of poverty rates in the European Union to macro-level changes”, Cambridge Journal of Economics, 30, 181-199.

Immervoll, H. and Pearson, M. (2009). A good time for making work pay? Taking stock of inwork benefits and related measures across the OECD. OECD Social, Employment and Migration working Papers No. 81, Paris: OECD.

Immervoll, H. (2012). "Minimum-Income Benefits in OECD Countries: Policy Design, Effectiveness and Challenges", in Measuring Poverty, Income Inequality, and Social Exclusion. Lessons from Europe, edited by D. Besharov, and K. Couch. Oxford University Press.

Immervoll, H. and Richardson, L. (2011). Redistribution Policy and Inequality Reduction in OECD Countries: What Has Changed in Two Decades?, IZA DP No. 6030. Bonn: Institute for the Study of Labor.

Jäntti, M. and Danziger, S. (2000). "Income Poverty in Advanced Countries”, in Handbook of income distribution, edited by A.B. Atkinson and F. Bourguignon. Amsterdam: Elsevier.

Jäntti, M., Bratsberg, B., Roed, K., Raaum, O., Naylor, R., Österbacka, E., Björklund A. and Eriksson, T. (2006). American exceptionalism in a new light: a comparison of intergenerational earnings mobility in the Nordic countries, the United Kingdom and the United States. IZA Discussion Paper No. 1938. Bonn: Institute for the Study of Labor.

Jenkins, S. P., Brandolini, A., Micklewright, J. and Nolan, B. (2013). The Great Recession and the Distribution of Household Income. Oxford: Oxford University Press. 
Jones, A. and O’Donnell, O. (1995). “Equivalence scales and the costs of disability”, Journal of Public Economics, 56(2), 273-289.

Kangas, O. (1995). “Attitudes to Means-tested Social Benefits in Finland”, Acta Sociologica 38: 299-310.

Kaplanoglou, G., Rapanos, V. and Bardakas, I. (2013). Does Fairness Matter for the Success of Fiscal Consolidation? Working Paper Available at SSRN: http://ssrn.com/abstract=2267831 or http://dx.doi.org/10.2139/ssrn.2267831.

Karoly, L., Kilburn, R. and Cannon, J. (2005). Early Childhood Interventions. Santa Monica, CA: Rand Corporation.

Kenworthy, L. (2004). Egalitarian Capitalism? Jobs, Incomes and Inequality in Affluent Countries. New York: Russell Sage Foundation.

Kenworthy, L. (2008). Jobs with Equality. Oxford: Oxford University Press.

Kenworthy, L. (2011). Progress for the Poor. Oxford: Oxford University Press.

Kluve, J. (2010). “The effectiveness of European active labor market programs”, Labour Economics, 17(6), 904-918.

Korpi, W. and J. Palme (1998). "The Paradox of Redistribution and Strategies of Equality: Welfare State Institutions, Inequality, and Poverty in the Western Countries”, American Sociological Review, 63(5), 661-687.

Kraus, M. (2004). "Social Security Strategies and Redistributive Effects in European Social Transfer Systems”, Review of Income and Wealth, 50(3), 431-57.

Kronauer, M. (1998). “'Social Exclusion' and 'Underclass' - New Concepts for the analysis of Poverty”, in Empirical Poverty Research in Comparative Perspective, edited by H-J Andreß. Aldershot: Ashgate.

Lampman, R. (1971). Ends and Means of Reducing Income Poverty. Chicago: Markham.

Lane, P.R. and Milesi-Ferretti, G.M. (2012). “External adjustment and the global crisis”, Journal of International Economics, Elsevier, 88(2), 252-265.

Layte, R. and Whelan, C.T. (2002). 'Cumulative Disadvantage or Individualization: A Comparative analysis of Poverty Risk and Incidence', European Societies, 4(2), 209223.

Lefebvre, M. (2007). The Redistributive Effects of Pension Systems in Europe: A Survey of Evidence. LIS Working Paper Series. Luxembourg Income Study (LIS) No. 457.

Leigh, A. (2010). "Who Benefits from the Earned Income Tax Credit? Incidence among Recipients, Coworkers and Firms”, The B.E. Journal of Economic Analysis \& Policy, Berkeley Electronic Press, 10(1).

Levine, R.A., Watts, H., Hollister, R., Williams, W., O’Connor, A. and Widerquist, K. (2005). "A Retrospective on the Negative Income Tax Experiments: Looking Back at the Most Innovative Field Studies in Social Policy', in The Ethics and Economics of the Basic Income Guarantee, edited by K. Widerquist. Aldershot: Ashgate.

Liebman, J. B. (2002). "Redistribution in the current U.S. social security system", in The Distributional Aspects of Social Security and Social Security Reform, edited by M. Feldstein and J. B. Liebman. Chicago: University of Chicago Press. 
Lohmann, H. (2009). "Welfare States, Labour Market Institutions and the Working Poor: A Comparative Analysis of 20 European Countries", European Sociological Review, 25(4), 26.

Lupton, R. (2003). Neighbourhood Effects: Can we measure them and does it matter?, CASEpaper 73, Centre for the Analysis of Social Exclusion, London: London School of Economics.

Maitre, B., Nolan, B. and Whelan, C. (2012). Low Pay, In-Work Poverty and Economic Vulnerability: an analysis using EU SILC. The Manchester School.

Machin, S. (2008). "Education and Inequality", in The Oxford Handbook of Economic Inequality, edited by W. Salverda, B. Nolan and T. Smeeding. Oxford: Oxford University Press.

Marchal, S., Marx, I. and Van Mechelen, N. (2014). "The Great-Wake Up Call? Social Citizenship and minimum income provisions in times of crisis”, Journal of Social Policy, 43(2), 247-267

Marical, F., Mira d'Ercole, M., Vaalavuo, M., and Verbist, G. (2008). Publicly-provided Services and the Distribution of Households' Economics Resources. OECD Economic Studies, 44(1), 9-47.

Marlier, E., Atkinson, A.B., Cantillon, B and Nolan, B. (2007). The EU and social inclusion: Facing the Challenges. Bristol Policy Press.

Marx, I., Vanhille, J. and Verbist, G. (2012). "Combating in-work poverty in Continental Europe: an investigation using the Belgian case”, Journal of Social Policy, 41(1), 1941.

Marx, I., Vandenbroucke, P. and Verbist, G. (2012b). "Will rising employment levels bring lower poverty : Regression based simulations of the Europe 2020 target”, Journal of European Social Policy, 22(5), 472-486.

Marx, I. and B. Nolan (2013). "In-work poverty", in Reconciling work and poverty reduction: how successful are European welfare states?, edited by B. Cantillon and F. Vandenbroucke. Oxford: Oxford University Press.

Marx, I., and K. Nelson (2013). Minimum Income Protection in Flux. Basingstoke: Palgrave Macmillan.

Marx, I., Marchal, S. and Nolan B. (2013). "Mind the Gap: Net Incomes of Minimum Wage Workers in the EU and the US", in Minimum income protection in the Flux, edited by I. Marx, and K. Nelson. Basingstoke: Palgrave MacMillan.

Marx, I., Salanauskaite, L. and G. Verbist (2013). The paradox of redistribution revisited, and that it may rest in peace? IZA Discussion paper series, No. 7414, Bonn: Institute for the Study of Labor.

Matsaganis, M. et al. (2005). Child Poverty and Family Transfers in Southern Europe, IZA Discussion paper series, No. 1509, Bonn: Institute for the Study of Labor.

Matsaganis M., Leventi C. (2013). “The distributional impact of the Greek crisis in 2010”. Fiscal Studies 34(1) 83-108.

Mayer, S. (1997). What Money Can’t Buy. Cambridge, MA: Harvard University Press.

Mayer, S. and Lopoo, L., (2008). “Government spending and intergenerational mobility”, Journal of Public Economics, 92(1-2), 139-158. 
Maurin, E. (2002). “The Impact of Parental Income on Early School Transitions.” Journal of Public Economics, 85(3): 301-32.

McLanahan, S. and Sandefur, G. (1994). Growing Up with a Single Parent. Cambridge: Harvard University Press.

Medgyesi, M. (forthcoming), Conditional cash transfers in OECD countries and their effects on human capital accumulation. AIAS, GINI Discussion Paper.

Meyer, D. and Wallace, G. (2009). "Poverty levels and trends in comparative perspective”, Focus, 26(2), 7-13, Madison: Institute for Research on Poverty.

Mincer, J. (1958). “Investment in Human Capital and Personal Income Distribution”, Journal of Political Economy, 66(4), 281-302.

Moene, K. and Wallerstein, M. (2001). “Inequality, Social Insurance and Redistribution”, American Political Science Review, 95(4), 859-874.

Moene K. and Wallerstein M. (2003). "Earnings Inequality and Welfare Spending: A Disaggregated Analysis”, World Politics, 55(4), 485-516.

Moffit, R. (1989). “Estimating the Value of an In-Kind Transfer: The Case of Food Stamps”, Econometrica, 57(2), 385-409.

Moller, S., Huber, E., Stephens, J. Bradley, D. and Nielsen, F. (2003). "Determinants of Relative Poverty in Advanced Capitalist Democracies”, American Sociological Review, 68(1), 22-51.

Morel, N., Palier, B. and Palme, J. (2011). Towards a social investment welfare state? Ideas, policies and challenges. Bristol: Policy Press.

Myles, J. (2000). "Poverty Indices and Poverty Analysis”, Review of Income and Wealth, 46, 161-79.

Nelson, K. (2004). "Mechanisms of poverty alleviation: anti-poverty effects of non-means tested and means-tested benefits in five welfare states", Journal of European Social Policy, 14(1), 371-390.

Nelson, K. (2007). "Universalism versus Targeting: The Vulnerability of Social Insurance and Means-Tested Minimum Income Protection in 18 Countries, 1990-2002", International Social Security Review 60: 33-58.

Nolan, B., Esping-Andersen, G., Whelan, C.T., Maitre, B., Wagner, S. (2011). "The Role of Social Institutions in Intergenerational Mobility” in Persistence, Privilege, Policy and Parenting, The Comparative Study of Intergenerational Mobility, edited by R. Erikson, M. Jantti and T. Smeeding. New York: Russell Sage Foundation.

Nolan, B. and Russell, H. (2001). Non-Cash Benefits and Poverty in Ireland. Policy Research Series Paper No. 39, Dublin: The Economic and Social Research Institute.

Nolan, B., and I. Marx (2009). "Inequality, Poverty and Social Exclusion", in Oxford Handbook of Economic Inequality, edited by W. Salverda, B. Nolan, and T. Smeeding. Oxford: Oxford University Press.

Nolan, B. and Marx, I. (2000). "Low Pay and Household Poverty", in Labour market inequalities: problems and policies of low-wage employment in international perspective, edited by M. Gregory, W. Salverda and S. Bazen, pp. 100-119. Oxford: Oxford University Press. 
Nolan, B. and Whelan, C.T. (1996). Resources, Deprivation and Poverty. Oxford: Clarendon Press.

Nolan, B and Whelan, C. T. (2010). "Using Non-Monetary Deprivation Indicators to Analyze Poverty and Social Exclusion: Lessons from Europe?”, Journal of Policy Analysis and Management, 29(2), 305-325.

Nolan, B. and Whelan, C.T. (2011). Poverty and Deprivation in Europe. Oxford: Oxford University Press.

Nolan, B. (2013). “What use is social investment?”, Journal of European Social Policy 23(5), 459-468.

Gassmann, F. and Notten, G. (2008). "Size Matters: Poverty reduction effects of meanstested and universal child benefits in Russia", European Journal of Social Policy, 18(3), 260-274.

OECD (2005). Labour Market Programmes and Activation Strategies: Evaluating the Impacts. Chapter 4 in OECD Employment Outlook 2005. Paris: OECD.

OECD (2007). Benefits and Wages. Paris: OECD.

OECD (2007b). Activating the Unemployed: What Countries Do. Chapter 5 in OECD Employment Outlook 2007. Paris: OECD.

OECD (2008). Growing Unequal: Income Distribution and Poverty in OECD Countries. Paris: OECD.

OECD (2009). Employment Outlook: Tackling the Jobs Crisis, Chapter 3, Is Work the Best Antidote to Poverty? pp. 165-210, Paris: OECD.

OECD (2011). Divided We Stand. Why Inequality Is Rising. Paris: OECD.

OECD (2011b). Pensions at a Glance 2011. Retirement Income Systems in OECD and G20 Countries. Paris: OECD.

OECD (2013). “Activating jobseekers: Lessons from seven OECD countries”, OECD Employment Outlook 2013. Paris: OECD.

Olivera, J. (2012). Preferences for redistribution in Europe. Working Papers 2012/25, Geary Institute, University College Dublin.

Page, M.E. (2004). "New Evidence on the intergenerational correlation in welfare participation", in Generational Income Mobility in North America and Europe, edited by M. Corak, pp. 226-244. Cambridge University Press.

Paulus, A., Sutherland, H. and Tsakloglou P. (2010). "The Distributional Impact of In-Kind Public Benefits in European Countries”, Journal of Policy Analysis and Management, 29(2), 243-266.

Pestieau, P. (2006). The Welfare State in the European Union. Oxford: Oxford University Press.

Piketty, T. (2003). The Impact of Divorce on School Performance. Evidence from France, 1968-2002. CEPR Discussion Paper 4146. London: CEPR.

Raaum, O., Salvanes, K. and Sørensen, E. (2003). “The Impact of a Primary School Reform on Educational Stratification: A Norwegian Study of Neighbour and School Mate Correlations.” Swedish Economic Policy Review, 10(2), 143-69. 
Raaum, O., Bratsberg, B., Røed, K., Österbacka, E., Eriksson, T., Jäntti, M. and Naylor, R. (2007). "Marital Sorting, Household Labor Supply, and Intergenerational Earnings Mobility across Countries", B.E. Journal of Economic Analysis and Policy, 7(2), Article 7.

Rothstein, J. (2010). "Is the EITC as Good as an NIT? Conditional Cash Transfers and Tax Incidence”, American Economic Journal: Economic Policy, 2(1), 177-208.

Sanbonmatsu, L., Kling, J., Duncan, G. and Brooks-Gunne, J. (2006). "Neighborhoods and academic achievement: Results from the Moving to Opportunity experiment”, Journal of Human Resources, 41 (4), 649-91.

Schütz, G., Ursprung, H., and Woessmann, L. (2005). Education Policy and Equality of Opportunity. IZA Discussion Paper, n. 1906. Bonn: Institute for the Study of Labor.

Sen, A. (1976). “Poverty: An Ordinal Approach to Measurement”, Econometrica, 44, 219-31.

Sen, A. (1980). "Equality of What”, in Tanner Lectures in Human Values I, edited by S.M. McMurrin. Cambridge: Cambridge University Press.

Sen, A. (1993). “Capability and Well-Being”, in The Quality of Life, edited by M. Nussbaum and A. Sen. Oxford: Oxford University Press.

Sigle-Rushton, W. (2004). Intergenerational and Life-Course Transmission of Social Exclusion in the 1970 British Cohort Study. Centre for Analysis of Social Exclusion Discussion Paper no. 78. London: London School of Economics and Political Science.

Skocpol T. (1991). "Targeting Within Universalism: Politically Viable Policies to Combat Poverty in the United States", in The Urban Underclass, edited by C. Jencks, P.E. Peterson, pp. 411-36. Washington, D.C.: The Brookings Institution.

Smeeding, T. M., Saunders, P., Coder, J., Jenkins, S.P., Fritzell, J., Hagenaars, A.J.M., Hauser, R. and Wolfson, M. (1993). "Poverty, Inequality, and Family Living Standards Impacts Across Seven Nations: The Effect of Noncash Subsidies for Health, Education, and Housing”. Review of Income and Wealth 39, 229-256.

Smeeding, T. and Sandstrom, S. (2005). "Poverty And Income Maintenance In Old Age: A Cross-National View Of Low Income Older Women”, Feminist Economics 11(2), 163174.

Smeeding, T. and Williamson, J. (2001). Income maintenance in old age: what can be learned from cross-national comparisons. LIS Working Paper No. 263. Luxembourg: Luxembourg Income Study.

Solon, G., Page, M. and Duncan, G. (2000). "Correlations between Neighboring Children in Their Subsequent Educational Attainment”, Review of Economics and Statistics, 82(3), 383-92.

Townsend, P. (1979). Poverty in the United Kingdom. Harmondsworth: Penguin.

Tsakloglou, P. and Papadopoulos, F. (2002). “Aggregate Level and Determining Factors of Social Exclusion in Twelve European Countries”, Journal of European Social Policy, 12(3), 2-9-23.

Tóth, I. (2014). "Revisiting Grand Narratives of Growing Inequalities: Lessons From 30 Country Studies", in Changing inequalities and societal impacts in rich countries: thirty countries' experiences, edited by B. Nolan W. Salverda, D. Checchi, I. Marx, A. McKnight, I. Gy. Tóth and H. van de Werfhorst. Oxford. Oxford University Press. 
Tsui, K. (2002). “Multidimensional Poverty Indices”, Social Choice and Welfare, 19, 69-93.

US Census Bureau (2003). Dynamics of Economic Well-Being: Poverty 1996-1999. Washington DC: US Census Bureau.

UNICEF (2007). “Child Poverty in Perspective: An Overview of Child Well-Being in Rich Countries”, Innocenti Report Card 7, Florence, Italy: UNICEF.

Valletta, R. (2006). "The Ins and Outs of Poverty in Advanced Economies: Government Policy and Poverty Dynamics in Canada, Germany, Great Britain, and the United States”, Review of Income and Wealth 52, 261-284.

Vandenbroucke, F., Hemerijck, A. and Palier, B. (2011). The EU Needs a Social Investment Pact, OSE Paper Series, Opinion paper No. 5, Observatoire Social Europeene, Brussels.

Vandenbroucke, F. and Vleminckx, K. (2011). "Disappointing poverty trends: Is the social investment state to blame?”, Journal of European Social Policy, 21: 432-449.

Vandenbroucke, F., Cantillon, B., Van Mechelen, N., Goedemé, T. and Van Lancker, A. (2013). "The EU and Minimum Income Protection: Clarifying the Policy Conundrum”, in Minimum Income Protection in Flux, edited by I. Marx and K. Nelson. Basingstoke: Palgrave MacMillan.

Van Kersbergen, and Hemerijck, A. (2012). "Two Decades of Change in Europe: The Emergence of the Social Investment State”, Journal of Social Policy, 41, 475-492; doi:10.1017/S0047279412000050

Van Lancker, W. and Ghysels J. (2012). "Who benefits? The social distribution of subsidized childcare in Sweden and Flanders”, Acta Sociologica, 55, 125-142.

Van Mechelen, N., and Marchal, S. (2013). "Struggle for Life: Social Assistance Benefits, 1992-2009”, in Minimum Income Protection in Flux, edited by I. Marx and K. Nelson. Basingstoke: Palgrave Macmillan.

Van Mechelen, N. and Bradshaw, J. (2013). “Child Poverty as a Government Priority: Child Benefit Packages for Working Families, 1992-2009”, in Minimum Income Protection in Flux, edited by I. Marx and K. Nelson. Basingstoke: Palgrave Macmillan.

Van Oorschot, W. (2002). "Targeting Welfare: on the Functions and Dysfunctions of Meanstesting in Social Policy”, in World Poverty: New Policies to Defeat an Old Enemy, edited by P. Townsend and D. Gordo. Bristol: The Policy Press.

Van Vliet, O., Been, J., Caminada, K. and Goudswaard, K. (2012). "Pension reform and income inequality among older people in 15 European countries”, International Journal of Social Welfare, 21: S8-S29.

Verbist, G. (2004). Redistributive Effect and Progressivity of Income Taxes: An International Comparison across the EU using EUROMOD. EUROMOD Working Paper EM5/04, The Microsimulation Unit, Cambridge University.

Verbist. G and Figari, F. (2014). The redistributive effect and progressivity of taxes revisited: an international comparison across the European Union. EUROMOD Working Paper Series: EM6/14.

Vignoli, D. and De Santis, G. (2010). "Individual and Contextual Correlates of Economic Difficulties in Old Age in Europe", Population Research and Policy Review 29: 481501.

Waldfogel, J. (2006). What Children Need. Cambridge, MA: Harvard University Press. 
Whelan, C.T., Layte, R. and Maître, B. (2003). "Persistent Income Poverty and Deprivation in the European Union”, Journal of Social Policy, 32(1), 1-18.

Whelan, C. T, Layte, R., Maître, B. and Nolan, B. (2001). "Income, Deprivation and Economic Strain: An Analysis of the European Community Household Panel”, European Sociological Review, 17(4), 357-372.

Whelan, C. T. and Maitre, B.; (2010). "Welfare Regime and social class variation in poverty and economic vulnerability in Europe: an Analysis of EU-SILC”, Journal of European Social Policy, 20(4), 316-332.

Whelan, C.T., Nolan, B. and Maître, B. (2013). “Analysing Intergenerational Influences on Income Poverty and Economic Vulnerability with EU-SILC”, European Societies, 15 (1), 82-105.

Whiteford, P. (2008). "How Much Redistribution Do Governments Achieve? The Role of Cash Transfers and Household Taxes', in Growing Unequal?, edited by OECD. Paris: OECD.

Whiteford, P. (2009). Transfer Issues and Directions for Reform: Australian Transfer Policy in Comparative Perspective. Unpublished. Social Policy Research Center, University of New South Wales.

Whiteford, P. and Adema, W. (2007). What works best in reducing child poverty: a benefit or work strategy?, OECD Social Employment and Migration Working Papers, No. 51, Paris: OECD.

Wilson, W. J. (1987). The truly disadvantaged: The inner city, the underclass and public policy. Chicago: University of Chicago Press.

Wolff, E. and Zacharias, A. (2007). "The Distributional Consequences Of Government Spending And Taxation In The U.S., 1989 And 2000”, Review of Income and Wealth, 53(4), 692-715.

Zaidi, A., Makovec, M., Fuchs, M., Lipszyc, B, Lelkes, O., Grech, A., Marin, B. and de Vos, K. (2006a). Poverty of Elderly People in EU25. Report submitted to the European Commission, Vienna: European Centre for Social Welfare Policy and Research.

Zaidi, A., Marin, B. and Fuchs, M. (2006b). Pension Policy in EU25 and its possible Impact on Elderly Poverty and Appendices. Report submitted to the European Commission, Vienna: European Centre for Social Welfare Policy and Research.

Zaidi, A. and Burchardt, T. (2005). "Comparing Incomes When Needs Differ: Equivalization For The Extra Costs Of Disability In The U.K”, Review of Income and Wealth, 51(1), 89-114.

Zheng, B. (2000). “Poverty Orderings”, Journal of Economic Surveys, 14, 427-66. 
Figure 1. Gini Coefficient for Disposable Income and Relative Income Poverty (60\% median), 2009, OECD

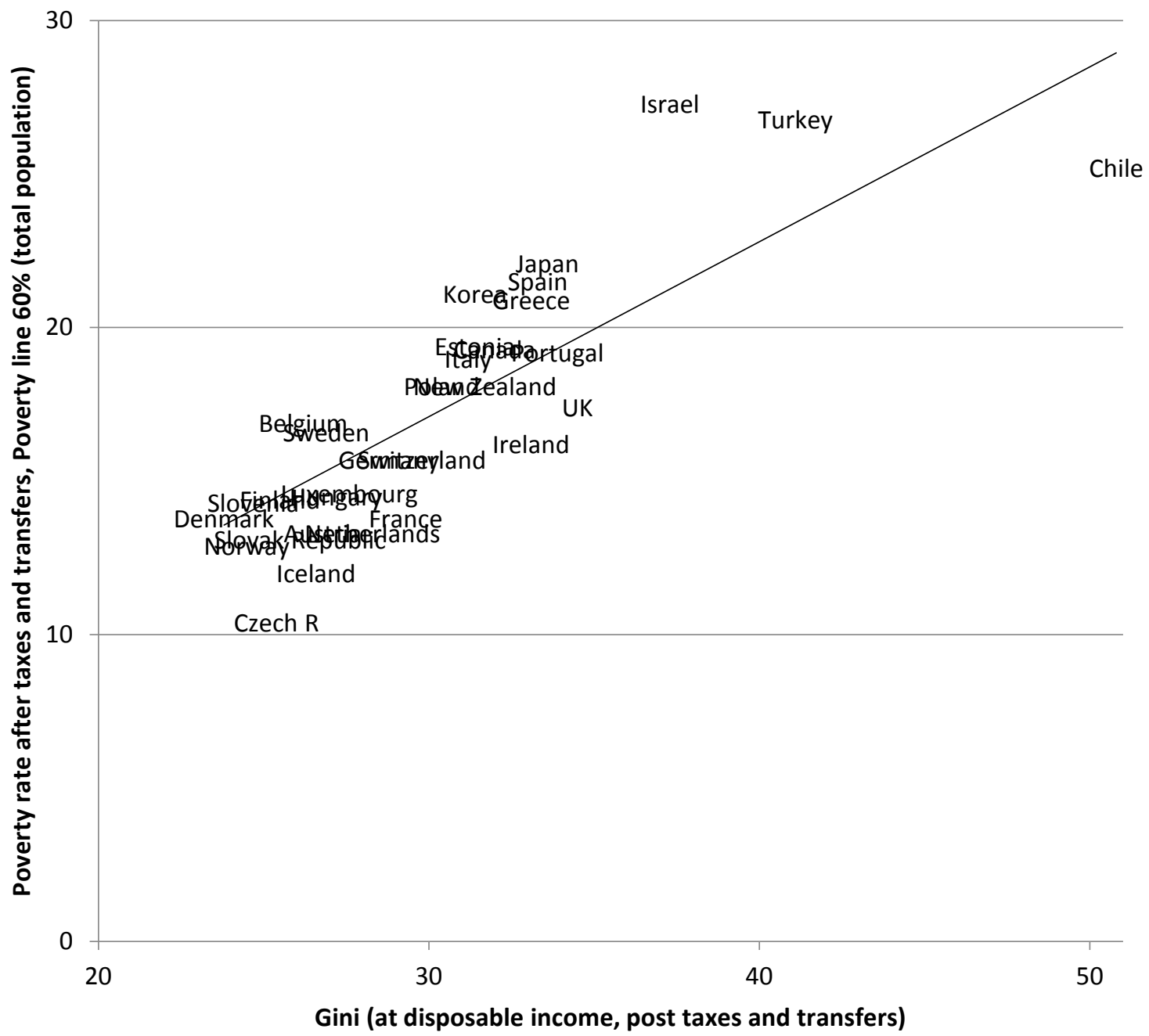

Source: OECD income distribution database. 
Figure 2. Cash public social expenditure and income inequality on working age in OECD countries, 2009

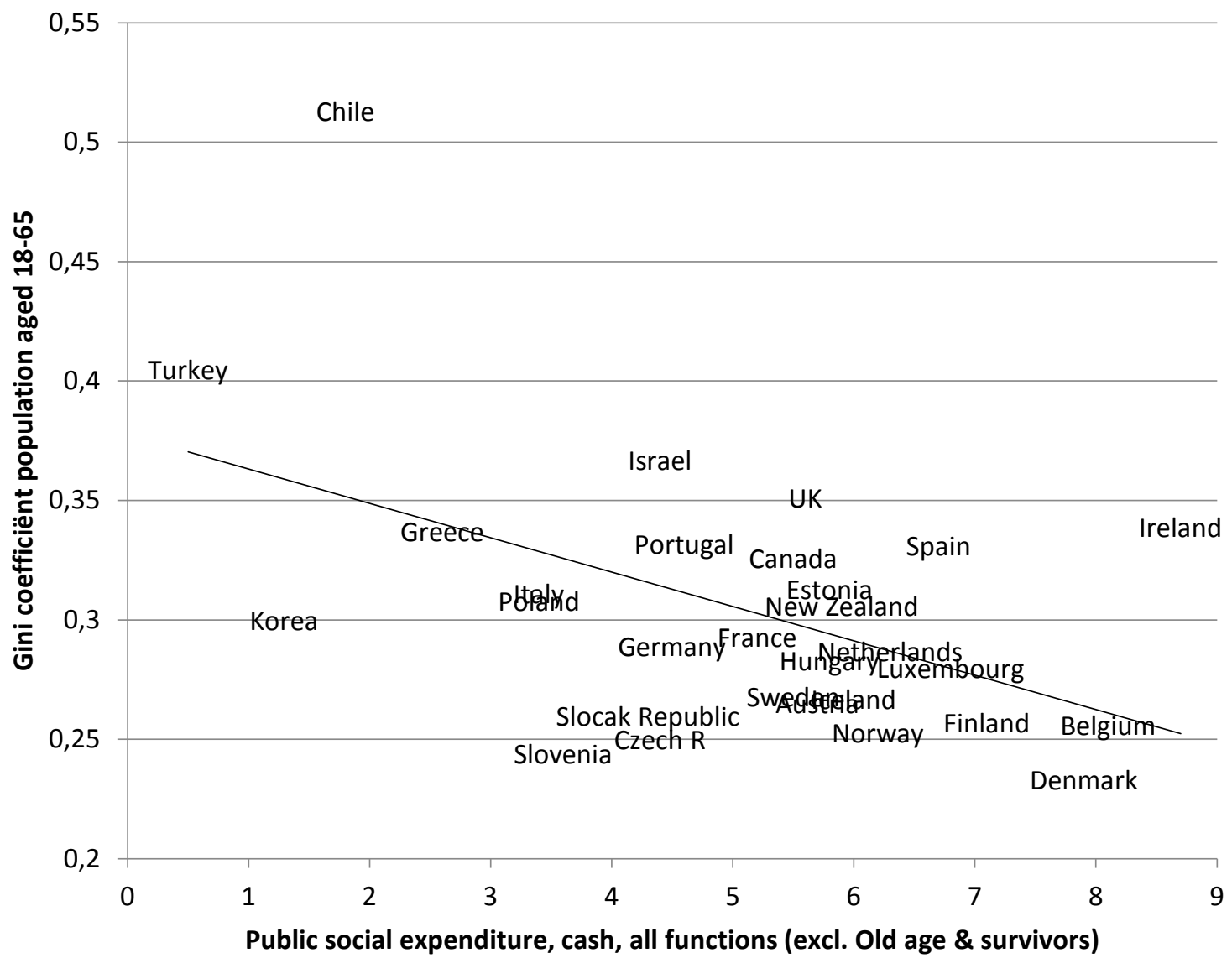

Note: Gini coefficient of equivalised disposable household income among the population aged 18-65. Source: OECD Divided We Stand (gini); OECD SOCX (social expenditure) 
Figure 3. Concentration index (ranking by gross income) and redistributive impact, mid 2000s.

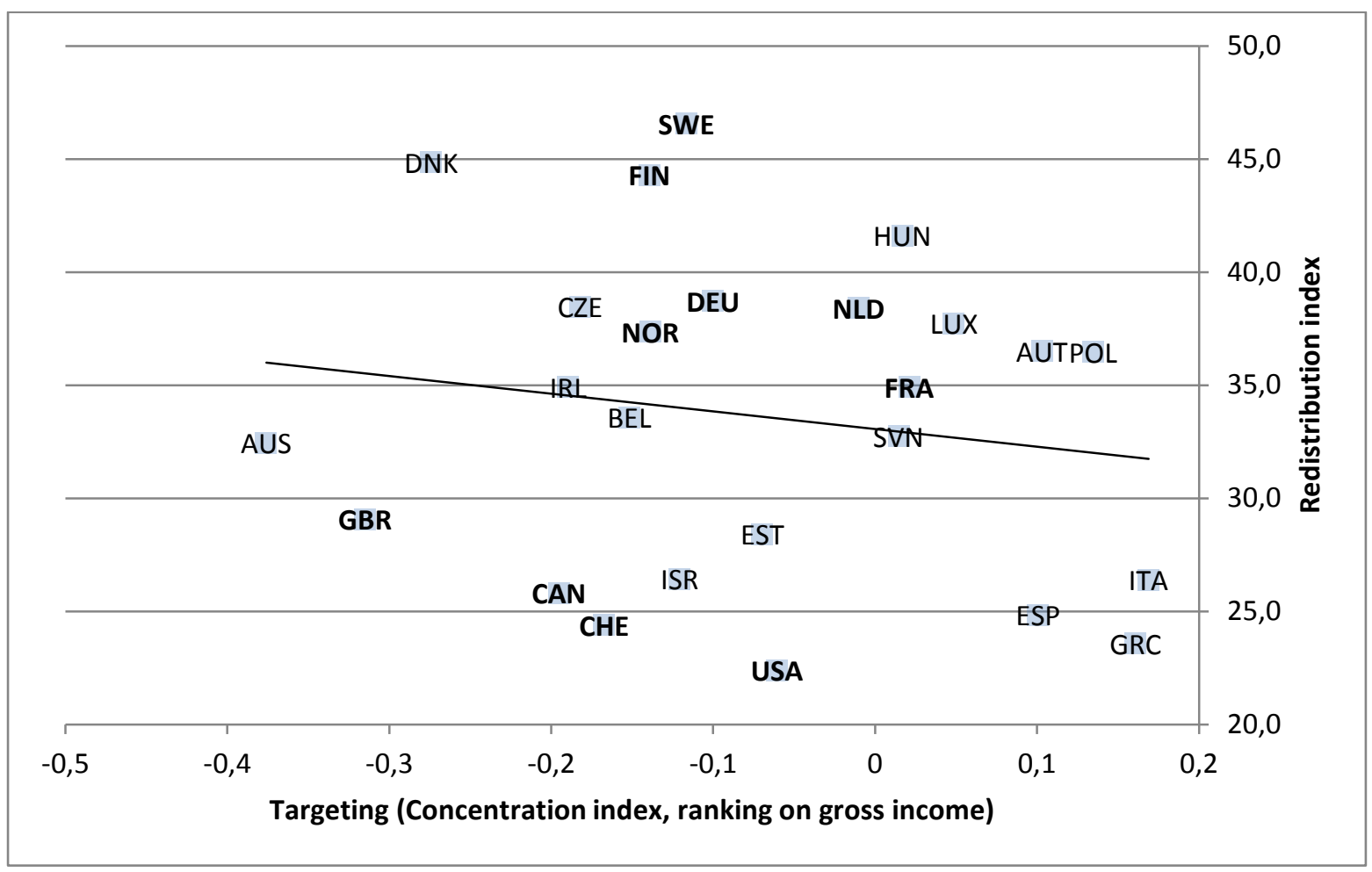

Note: 1) for Belgium, France, Greece, Hungary, Slovenia and Spain calculations are based on disposable incomes instead of gross incomes due to data availability. 2) The countries included in Korpi and Palme (1998) are in bold.

Source: Marx, Salanauskaite and Verbist (2013) on the basis of the Luxembourg Income Study 
Figure 4. The level of the social safety net in the EU and three US States, 2012

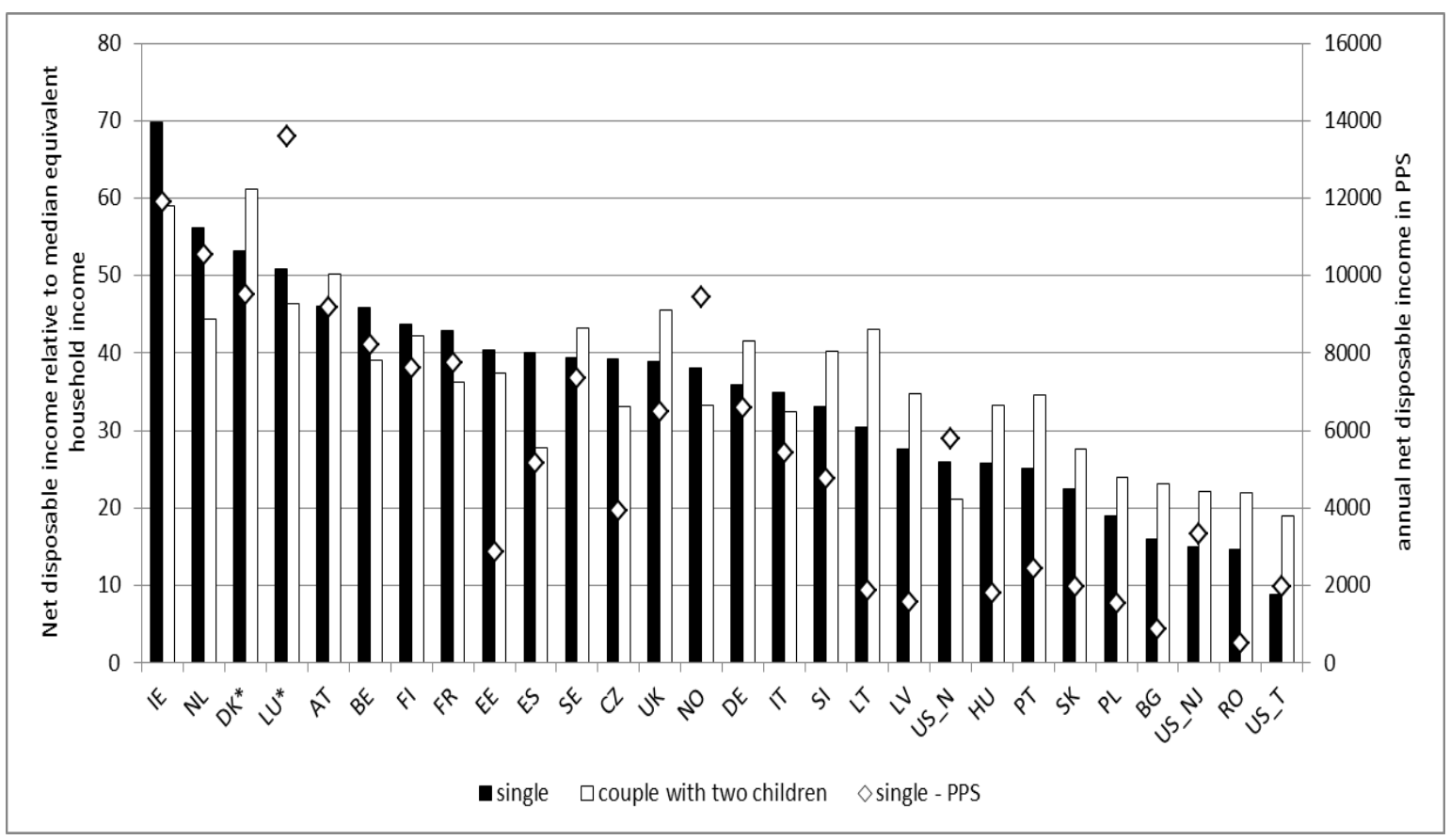

Note: In some countries, such as the US, Italy and Bulgaria, time limits apply, either formal or discretionary. In order to avoid additional assumptions, the levels displayed do not take these time limits into account.

Source: Source: CSB-MIPI (Van Mechelen, et al., 2011), (Eurostat, 2011; U.S. Bureau of the Census and Bureau of Labour Statistics, 2011) 
Figure 5. Gross minimum wages and net incomes at minimum wage as a percentage of the relative poverty threshold, 2012, selected EU Member States plus United States (New Jersey)

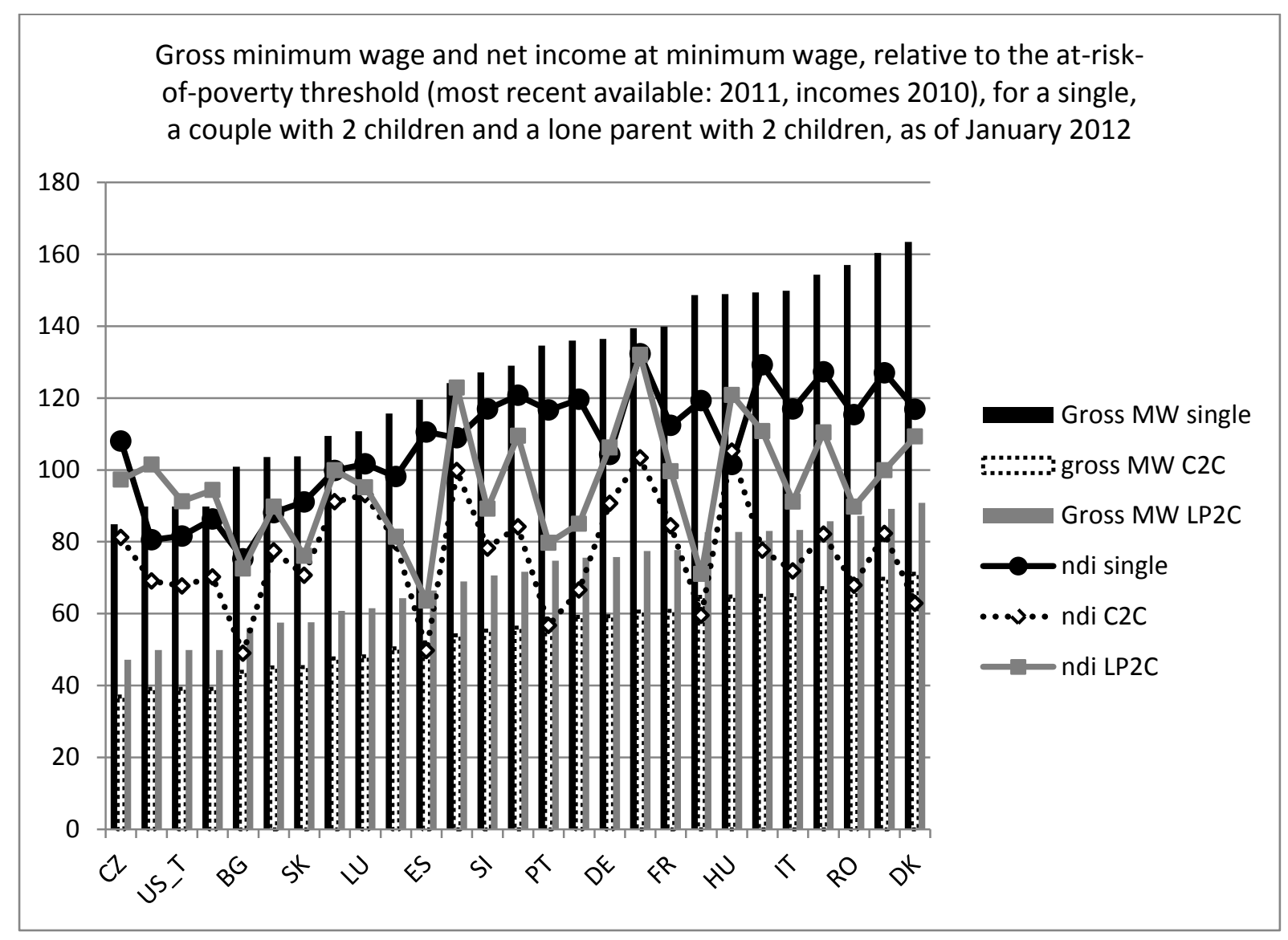

Source: CSB-MIPI (Van Mechelen, et al., 2011), (Eurostat, 2011; U.S. Bureau of the Census and Bureau of Labour Statistics, 2011) 
Figure 6. Taxonomy of different types of retirement-income provision

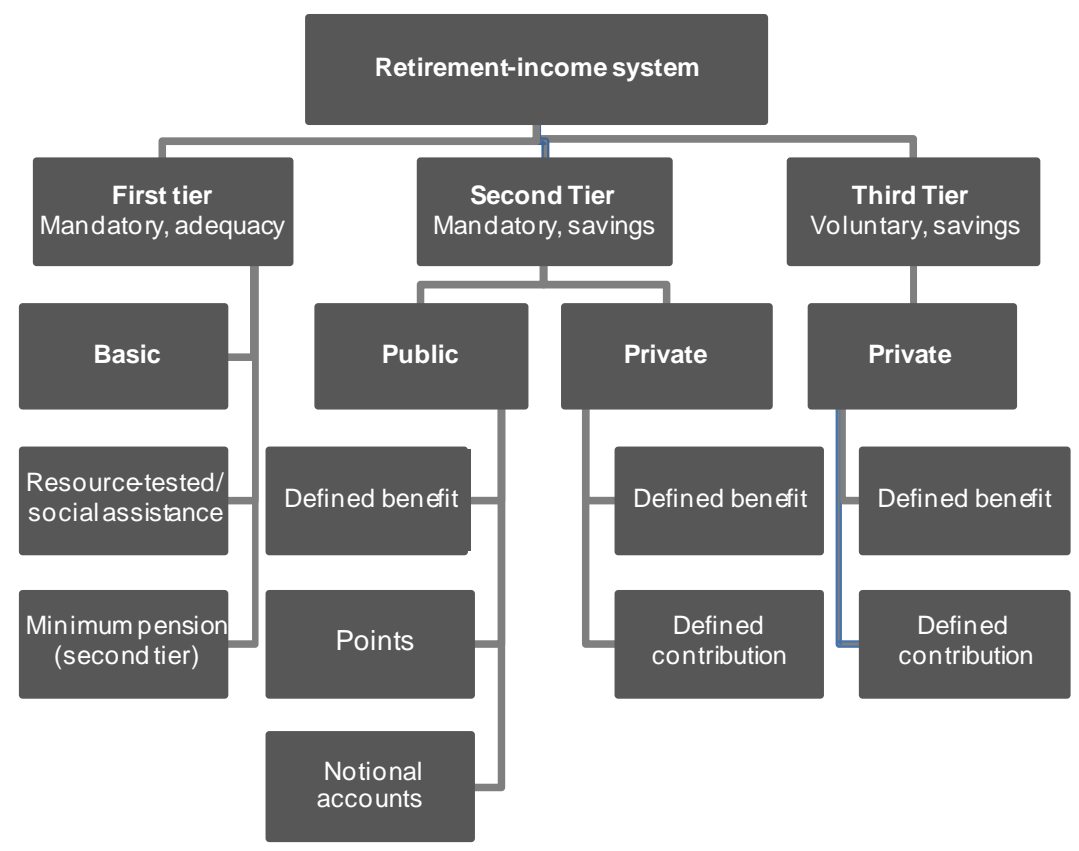

Source: OECD (2011b) 
Figure 7. Net pension replacement rates by pension schemes in OECD countries

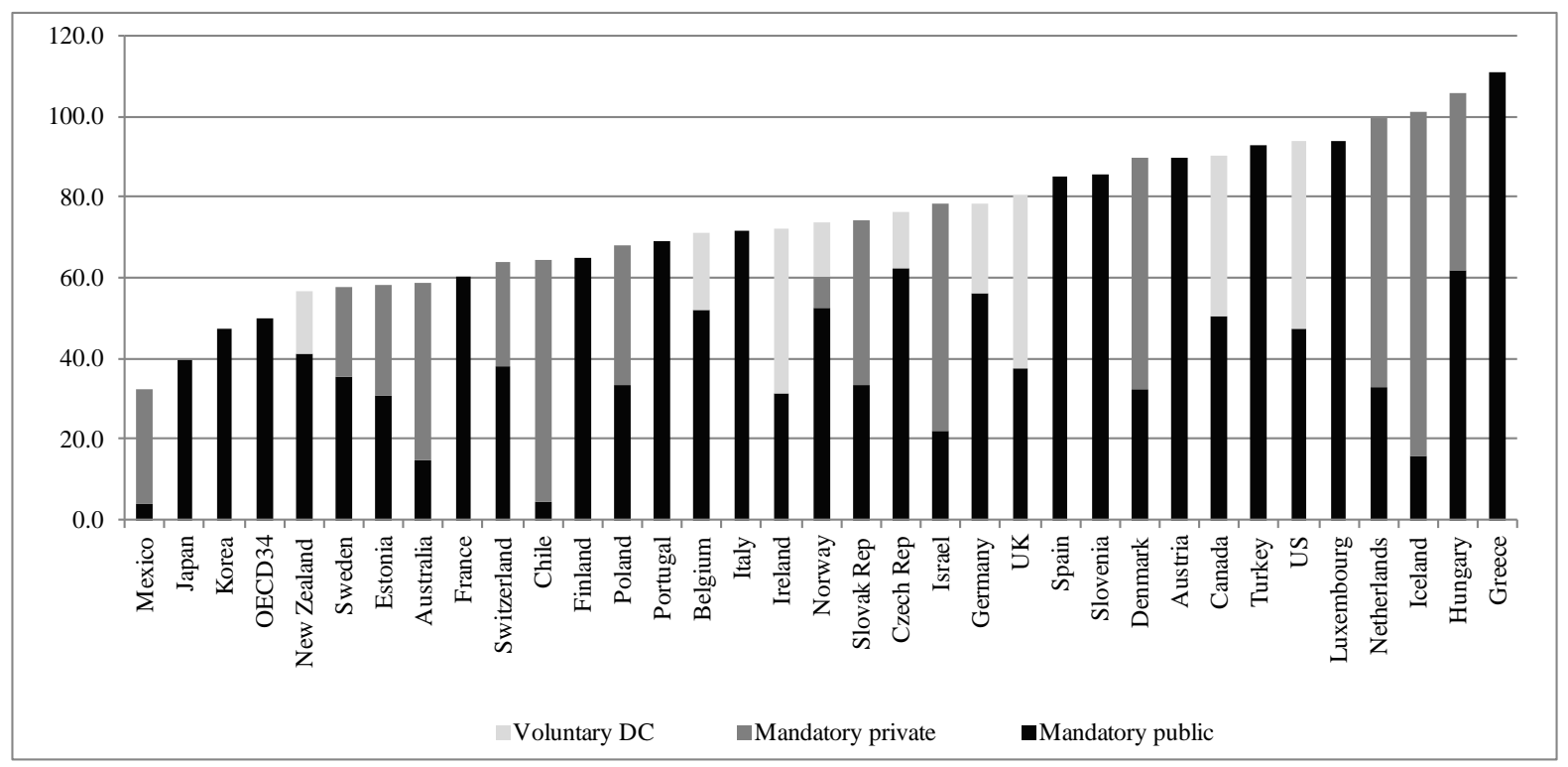

Source: OECD (2011b). Authors' elaboration. 
Figure 8. Risk of relative poverty by age of individuals in OECD-7 countries (Poverty rate of the entire population in each year $=100$ )

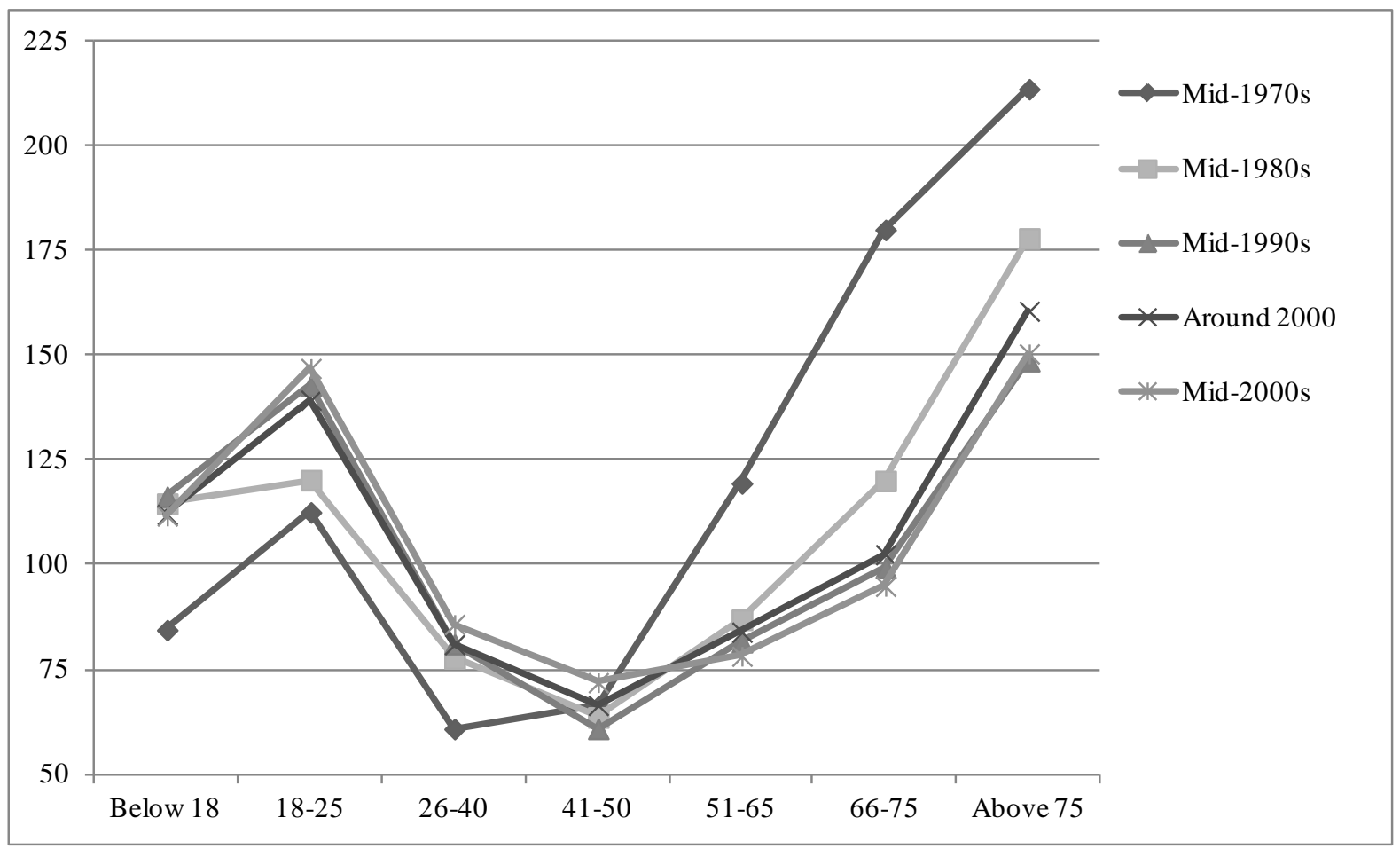

Note: Relative poverty risk is the age-specific poverty rate divided by the poverty rate for the entire population times 100 . The poverty threshold is set at $50 \%$ of median income of the entire population. OECD-7 is the average for Canada, Finland, Greece, the Netherlands, Sweden, the United Kingdom and the United States. Source: OECD (2008). 
Table 1. Income Poverty Rates in OECD Countries, Mid-2000s

\begin{tabular}{|l|c|c|}
\hline Country & \% below 50\% of median income & \% below 60\% of median income \\
\hline Australia (2003) & 12.3 & 20.4 \\
\hline Austria (2004) & 7.1 & 13.4 \\
\hline Belgium (2000) & 8.1 & 16.1 \\
\hline Canada (2007) & 11.9 & 18.7 \\
\hline Czech Rep (2004) & 5.8 & 11.4 \\
\hline Denmark (2004) & 5.6 & 13.2 \\
\hline Estonia (2004) & 12.8 & 20.4 \\
\hline Finland (2004) & 6.6 & 13.7 \\
\hline France (2005) & 8.5 & 14.9 \\
\hline Germany (2007) & 8.4 & 14.6 \\
\hline Greece (2004) & 11.9 & 19.6 \\
\hline Hungary (2005) & 7.4 & 12.5 \\
\hline Ireland (2004) & 13.2 & 22.0 \\
\hline Italy (2008) & 11.9 & 19.7 \\
\hline Luxembourg (2004) & 8.9 & 13.8 \\
\hline Mexico (2004) & 18.3 & 25.5 \\
\hline Netherlands (2004) & 6.3 & 11.8 \\
\hline Norway (2004) & 7.1 & 12.8 \\
\hline Poland (2004) & 10.7 & 17.2 \\
\hline Slovenia (2004) & 7.1 & 11.7 \\
\hline Spain (2007) & 13.7 & 20.3 \\
\hline Sweden (2005) & 5.6 & 12.0 \\
\hline Switzerland (2004) & 8.0 & 14.8 \\
\hline UK (2004) & 11.2 & 19.0 \\
\hline USA (2007) & 17.7 & 24.4 \\
\hline
\end{tabular}

Source: LIS, downloaded 
Table 2. Income Poverty Rates for Children and Elderly in OECD Countries, Mid-2000s

\begin{tabular}{|l|c|c|c|}
\hline Country & \multicolumn{3}{|c|}{ \% of below 50\% of median income } \\
\hline & Children & Elderly (65+) & All \\
\hline Australia (2003) & 14.0 & 22.3 & 12.3 \\
\hline Austria (2004) & 6.8 & 9.4 & 7.1 \\
\hline Belgium (2000) & 7.2 & 15.4 & 8.1 \\
\hline Canada (2007) & 15.0 & 8.3 & 11.9 \\
\hline Czech Rep (2004) & 10.2 & 2.1 & 5.8 \\
\hline Denmark (2004) & 3.9 & 8.5 & 5.6 \\
\hline Estonia (2004) & 15.4 & 13.5 & 12.8 \\
\hline Finland (2004) & 4.1 & 10.3 & 6.6 \\
\hline France (2005) & 10.2 & 7.4 & 8.5 \\
\hline Germany (2007) & 9.3 & 9.0 & 8.4 \\
\hline Greece (2004) & 12.4 & 18.8 & 11.9 \\
\hline Hungary (2005) & 9.9 & 4.0 & 7.4 \\
\hline Ireland (2004) & 15.9 & 23.8 & 13.2 \\
\hline Italy (2008) & 17.1 & 11.0 & 11.9 \\
\hline Luxembourg (2004) & 13.5 & 4.7 & 8.9 \\
\hline Mexico (2004) & 22.2 & 27.1 & 18.3 \\
\hline Netherlands (2004) & 9.2 & 2.4 & 6.3 \\
\hline Norway (2004) & 5.3 & 8.5 & 7.1 \\
\hline Poland (2004) & 15.6 & 3.5 & 10.7 \\
\hline Slovenia (2004) & 5.5 & 16.4 & 7.1 \\
\hline Spain (2007) & 17.3 & 20.7 & 13.7 \\
\hline Sweden (2005) & 4.7 & 6.6 & 5.6 \\
\hline Switzerland (2004) & 9.3 & 15.1 & 8.0 \\
\hline UK (2004) & 13.0 & 16.3 & 11.2 \\
\hline USA (2004) & 22.0 & 24.2 & 17.7 \\
\hline
\end{tabular}

Source: LIS downloaded 
Table 3: Income Poverty Rates Pre- and Post-Transfers in EU Countries, 2007

\begin{tabular}{|c|c|c|c|c|}
\hline \multirow[t]{2}{*}{ Country } & \multirow{2}{*}{$\begin{array}{c}\begin{array}{c}\text { Pre-transfer } \\
\text { poverty }\end{array} \\
\%\end{array}$} & \multirow{2}{*}{$\begin{array}{c}\begin{array}{c}\text { Post-transfer } \\
\text { poverty }\end{array} \\
\%\end{array}$} & \multicolumn{2}{|c|}{ Reduction in poverty } \\
\hline & & & \% point & $\%$ \\
\hline Belgium & 27.5 & 15.2 & 12.3 & 44.7 \\
\hline Bulgaria & 25.5 & 22.0 & 3.5 & 13.7 \\
\hline Croch Ren & 20.1 & 9.6 & 10.5 & 52.2 \\
\hline Czech Rep & 27.1 & 11.7 & 15.4 & 56.8 \\
\hline Denmark & 24.8 & 15.2 & 9.6 & 38.7 \\
\hline Germany & 25.2 & 19.4 & 5.8 & 23.0 \\
\hline Estonia & 33.1 & 17.2 & 15.9 & 48.0 \\
\hline Ireland & 23.7 & 20.3 & 3.4 & 14.3 \\
\hline Greece & 23.9 & 19.7 & 4.2 & 17.6 \\
\hline Spain & 26.4 & 13.1 & 13.3 & 50.4 \\
\hline France & 24.1 & 19.8 & 4.3 & 17.8 \\
\hline Italy & 21.0 & 15.5 & 5.5 & 26.2 \\
\hline Cyprus & 27.2 & 21.2 & 6.0 & 22.1 \\
\hline Latvia & 25.5 & 19.1 & 6.4 & 25.1 \\
\hline Ldivid & 23.4 & 13.5 & 9.9 & 42.3 \\
\hline Lithuania & 29.3 & 12.3 & 17.0 & 58.0 \\
\hline Luxembourg & 21.2 & 14.8 & 6.4 & 30.2 \\
\hline Hungary & 20.6 & 10.2 & 10.4 & 50.5 \\
\hline Malta & 24.7 & 12.0 & 12.7 & 51.4 \\
\hline Netherlands & 26.5 & 17.3 & 9.2 & 34.7 \\
\hline Austria & 24.2 & 18.1 & 6.1 & 25.2 \\
\hline Poland & 30.9 & 24.8 & 6.1 & 19.7 \\
\hline Portugal & 23.1 & 11.5 & 11.6 & 50.2 \\
\hline Romania & 18.2 & 10.6 & 7.6 & 41.8 \\
\hline Slovenia & 28.9 & 13.0 & 15.9 & 55.0 \\
\hline Slovenia & 27.5 & 10.5 & 17.0 & 61.8 \\
\hline Slovakia & 29.7 & 18.6 & 11.1 & 37.4 \\
\hline Finland & & & & \\
\hline Sweden & & & & \\
\hline UK & & & & \\
\hline
\end{tabular}

Eurostat downloaded. 
Table 4. Social Expenditure Distinguishing Cash and Non-Cash Benefits as Percentage of GDP in OECD Countries, Mid-2000s

\begin{tabular}{|l|c|c|}
\hline Country & $\begin{array}{c}\text { Cash transfers } \\
\text { \% of GDP }\end{array}$ & $\begin{array}{c}\text { Non-cash social benefits } \\
\text { \% of GDP P }\end{array}$ \\
\hline Australia & 8.1 & 6.7 \\
\hline Austria & 18.4 & 8.2 \\
\hline Belgium & 16.2 & 9.1 \\
\hline Canada & 8.8 & 9.4 \\
\hline Czech Republic & 11.4 & 7.8 \\
\hline Denmark & 13.8 & 11.8 \\
\hline Finland & 15.3 & 9.9 \\
\hline France & 17.5 & 10.8 \\
\hline Germany & 15.9 & 9.9 \\
\hline Greece & 13.4 & 7.1 \\
\hline Hungary & 13.8 & 8.7 \\
\hline Ireland & 8.4 & 7.7 \\
\hline Italy & 16.7 & 7.7 \\
\hline Japan & 10.2 & 8.1 \\
\hline Luxembourg & 13.9 & 8.8 \\
\hline Netherlands & 11.1 & 8.5 \\
\hline New Zealand & 9.7 & 8.4 \\
\hline Norway & 10.9 & 10.1 \\
\hline Poland & 15.7 & 4.9 \\
\hline Slovak Republic & 10.2 & 6.1 \\
\hline Spain & 13.1 & 7.4 \\
\hline Sweden & 14.5 & 13.6 \\
\hline Switzerland & 11.8 & 7.8 \\
\hline UK & 10.3 & 10.5 \\
\hline USA & 8.0 & 7.0 \\
\hline
\end{tabular}

Source: OECD Social Expenditure Database 
Table 5. Relative Income Poverty Rates (60\% of Median Threshold), European Union Countries 2007-2011

\begin{tabular}{|l|c|c|c|c|c|}
\hline \multirow{2}{*}{ Country } & $\mathbf{2 0 0 7}$ & $\mathbf{2 0 0 8}$ & $\mathbf{2 0 0 9}$ & $\mathbf{2 0 1 0}$ & $\mathbf{2 0 1 1}$ \\
\cline { 2 - 6 } & $\mathbf{9}$ & $\mathbf{\%}$ & $\mathbf{\%}$ & $\mathbf{\%}$ & $\mathbf{\%}$ \\
\hline Belgium & 15.2 & 14.7 & 14.6 & 14.6 & 15.3 \\
\hline Bulgaria & 22.0 & 21.4 & 21.8 & 20.7 & 22.3 \\
\hline Czech Republic & 9.6 & 9.0 & 8.6 & 9.0 & 9.8 \\
\hline Denmark & 11.7 & 11.8 & 13.1 & 13.3 & 13.0 \\
\hline Germany & 15.2 & 15.2 & 15.5 & 15.6 & 15.8 \\
\hline Estonia & 19.4 & 19.5 & 19.7 & 15.8 & 17.5 \\
\hline Ireland & 17.2 & 15.5 & 15.0 & 16.1 & $:$ \\
\hline Greece & 20.3 & 20.1 & 19.7 & 20.1 & 21.4 \\
\hline Spain & 19.7 & 19.6 & 19.5 & 20.7 & 21.8 \\
\hline France & 13.1 & 12.7 & 12.9 & 13.3 & 14.0 \\
\hline Italy & 19.8 & 18.7 & 18.4 & 18.2 & 19.6 \\
\hline Cyprus & 15.5 & 15.9 & 15.8 & 15.1 & 14.5 \\
\hline Latvia & 21.2 & 25.6 & 25.7 & 21.3 & 19.1 \\
\hline Lithuania & 19.1 & 20.0 & 20.6 & 20.2 & 20.0 \\
\hline Luxembourg & 13.5 & 13.4 & 14.9 & 14.5 & 13.6 \\
\hline Hungary & 12.3 & 12.4 & 12.4 & 12.3 & 13.8 \\
\hline Malta & 14.8 & 15.0 & 15.3 & 15.0 & 15.4 \\
\hline Netherlands & 10.2 & 10.5 & 11.1 & 10.3 & 11.0 \\
\hline Austria & 12.0 & 12.4 & 12.0 & 12.1 & 12.6 \\
\hline Poland & 17.3 & 16.9 & 17.1 & 17.6 & 17.7 \\
\hline Portugal & 18.1 & 18.5 & 17.9 & 17.9 & 18.0 \\
\hline Romania & 24.8 & 23.4 & 22.4 & 21.1 & 22.2 \\
\hline Slovenia & 11.5 & 12.3 & 11.3 & 12.7 & 13.6 \\
\hline Slovakia & 10.6 & 10.9 & 11.0 & 12.0 & 13.0 \\
\hline Finland & 13.0 & 13.6 & 13.8 & 13.1 & 13.7 \\
\hline Sweden & 10.5 & 12.2 & 13.3 & 12.9 & 14.0 \\
\hline United Kingdom & 18.6 & 18.7 & 17.3 & 17.1 & 16.2 \\
\hline Iceland & 10.1 & 10.1 & 10.2 & 9.8 & 9.2 \\
\hline Norway & 11.9 & 11.4 & 11.7 & 11.2 & 10.5 \\
\hline Switzerland & $:$ & 16.2 & 15.1 & 15.0 & 15.0 \\
\hline Croatia & 18 & 17.3 & 17.9 & 20.5 & 21.1 \\
\hline European Union (27 countries) & 16.5 & 16.4 & 16.3 & 16.4 & 16.9 \\
\hline & & & & & \\
\hline
\end{tabular}

Note: The household income statistics in Eurostat are mainly produced with EU-SILC data, which reference period is a fixed 12-month period (such as the previous calendar or tax year) for all countries except UK for which the income reference period is the current year and IE for which the survey is continuous and income is collected for the last twelve months.

Source: Eurostat (downloaded 20 March 2013) 
Table 6. 'Anchored' Income Poverty Rates (60\% of Median Threshold in 2008, Indexed to Consumer Prices Subsequently), European Union Countries 2008-2011

\begin{tabular}{|l|c|c|c|c|}
\hline \multirow{2}{*}{ Country } & $\mathbf{2 0 0 8}$ & $\mathbf{2 0 0 9}$ & $\mathbf{2 0 1 0}$ & $\mathbf{2 0 1 1}$ \\
\cline { 2 - 5 } & $\mathbf{\%}$ & $\mathbf{\%}$ & $\mathbf{\%}$ & $\mathbf{\%}$ \\
\hline Belgium & 14.7 & 13.1 & 13.0 & 13.5 \\
\hline Bulgaria & 21.4 & 16.1 & 14.8 & 17.8 \\
\hline Czech Republic & 9.0 & 8.1 & 7.8 & 8.6 \\
\hline Denmark & 11.8 & 13.1 & 12.6 & 12.2 \\
\hline Germany & 15.2 & 16.0 & 15.8 & 15.9 \\
\hline Estonia & 19.5 & 18.9 & 19.7 & 23.9 \\
\hline Ireland & 15.5 & 15.4 & 22.8 & $:$ \\
\hline Greece & 20.1 & 18.9 & 18.0 & 24.9 \\
\hline Spain & 19.6 & 20.2 & 22.3 & 25.7 \\
\hline France & 12.7 & 12.7 & 12.3 & 13.9 \\
\hline Italy & 18.7 & 19.9 & 19.3 & 21.4 \\
\hline Cyprus & 15.9 & 16.3 & 16.2 & 14.4 \\
\hline Latvia & 25.6 & 26.0 & 33.0 & 36.2 \\
\hline Lithuania & 20.0 & 18.6 & 28.4 & 30.8 \\
\hline Luxembourg & 13.4 & 15.5 & 14.4 & 14.6 \\
\hline Hungary & 12.4 & 11.8 & 13.7 & 14.7 \\
\hline Malta & 15.0 & 14.3 & 16.5 & 15.9 \\
\hline Netherlands & 10.5 & 10.6 & 10.0 & 11.0 \\
\hline Austria & 12.4 & 11.4 & 11.0 & 10.5 \\
\hline Poland & 16.9 & 13.7 & 13.0 & 11.9 \\
\hline Portugal & 18.5 & 18.1 & 16.1 & 17.9 \\
\hline Romania & 23.4 & 18.2 & 16.2 & 17.9 \\
\hline Slovenia & 12.3 & 10.2 & 12.1 & 13.0 \\
\hline Slovakia & 10.9 & 7.8 & 7.3 & 7.0 \\
\hline Finland & 13.6 & 13.0 & 12.0 & 12.3 \\
\hline Sweden & 12.2 & 11.7 & 11.2 & 11.6 \\
\hline United Kingdom & 18.7 & 20.4 & 21.4 & 21.8 \\
\hline Iceland & 10.1 & 9.8 & 16.7 & 23.7 \\
\hline Norway & 11.4 & 10.2 & 9.6 & 8.9 \\
\hline Switzerland & 16.2 & 13.8 & 13.8 & 13.1 \\
\hline European Union (27 countries) & 16.4 & 16.3 & 16.4 & 17.5 \\
\hline & & & & \\
\hline Note: & & 1 & \\
\hline
\end{tabular}

Note: The household income statistics in Eurostat are mainly produced with EU-SILC data, which reference period is a fixed 12-month period (such as the previous calendar or tax year) for all countries except UK for which the income reference period is the current year and IE for which the survey is continuous and income is collected for the last twelve months.

Source: Eurostat (downloaded 20 March 2013) 
Table 7: Severe Material Deprivation Rate, European Union Countries 2008-2011

\begin{tabular}{|l|c|c|c|c|c|}
\hline \multirow{2}{*}{ Country } & $\mathbf{2 0 0 7}$ & $\mathbf{2 0 0 8}$ & $\mathbf{2 0 0 9}$ & $\mathbf{2 0 1 0}$ & $\mathbf{2 0 1 1}$ \\
\cline { 2 - 5 } & $\mathbf{\%}$ & $\mathbf{\%}$ & $\mathbf{9}$ & $\mathbf{\%}$ & $\boldsymbol{\%}$ \\
\hline Belgium & 5.7 & 5.6 & 5.2 & 5.9 & 5.7 \\
\hline Bulgaria & 57.6 & 41.2 & 41.9 & 45.7 & 43.6 \\
\hline Czech Republic & 7.4 & 6.8 & 6.1 & 6.2 & 6.1 \\
\hline Denmark & 3.3 & 2.0 & 2.3 & 2.7 & 2.6 \\
\hline Germany & 4.8 & 5.5 & 5.4 & 4.5 & 5.3 \\
\hline Estonia & 5.6 & 4.9 & 6.2 & 9.0 & 8.7 \\
\hline Ireland & 4.5 & 5.5 & 6.1 & 7.5 & $:$ \\
\hline Greece & 11.5 & 11.2 & 11.0 & 11.6 & 15.2 \\
\hline Spain & 3.0 & 2.5 & 3.5 & 4.0 & 3.9 \\
\hline France & 4.7 & 5.4 & 5.6 & 5.8 & 5.2 \\
\hline Italy & 6.8 & 7.5 & 7.0 & 6.9 & 11.2 \\
\hline Cyprus & 13.3 & 9.1 & 9.5 & 10.1 & 10.8 \\
\hline Latvia & 24.9 & 19.0 & 21.9 & 27.4 & 31.4 \\
\hline Lithuania & 16.6 & 12.3 & 15.1 & 19.5 & 18.5 \\
\hline Luxembourg & 0.8 & 0.7 & 1.1 & 0.5 & 1.2 \\
\hline Hungary & 19.9 & 17.9 & 20.3 & 21.6 & 23.1 \\
\hline Malta & 4.2 & 4.0 & 4.7 & 5.7 & 6.3 \\
\hline Netherlands & 1.7 & 1.5 & 1.4 & 2.2 & 2.5 \\
\hline Austria & 3.3 & 6.4 & 4.8 & 4.3 & 3.9 \\
\hline Poland & 22.3 & 17.7 & 15.0 & 14.2 & 13.0 \\
\hline Portugal & 9.6 & 9.7 & 9.1 & 9.0 & 8.3 \\
\hline Romania & 36.5 & 32.9 & 32.2 & 31.0 & 29.4 \\
\hline Slovenia & 5.1 & 6.7 & 6.1 & 5.9 & 6.1 \\
\hline Slovakia & 13.7 & 11.8 & 11.1 & 11.4 & 10.6 \\
\hline Finland & 3.6 & 3.5 & 2.8 & 2.8 & 3.2 \\
\hline Sweden & 2.2 & 1.4 & 1.6 & 1.3 & 1.2 \\
\hline United Kingdom & 4.2 & 4.5 & 3.3 & 4.8 & 5.1 \\
\hline Iceland & 2.1 & 0.8 & 0.8 & 1.8 & 2.1 \\
\hline Norway & 2.3 & 2.0 & 2.2 & 2.0 & 2.3 \\
\hline Switzerland & $:$ & 2.2 & 2.1 & 1.7 & 1.0 \\
\hline Croatia & $:$ & $:$ & $:$ & 14.5 & 14.8 \\
\hline European Union (27 countries) & 9.1 & 8.4 & 8.1 & 8.3 & 8.8 \\
\hline & & & & & \\
\hline
\end{tabular}

Source: Eurostat (downloaded 20 March 2013) 